\title{
Western Energy Corridor - Energy Resource Report
}

June 2011

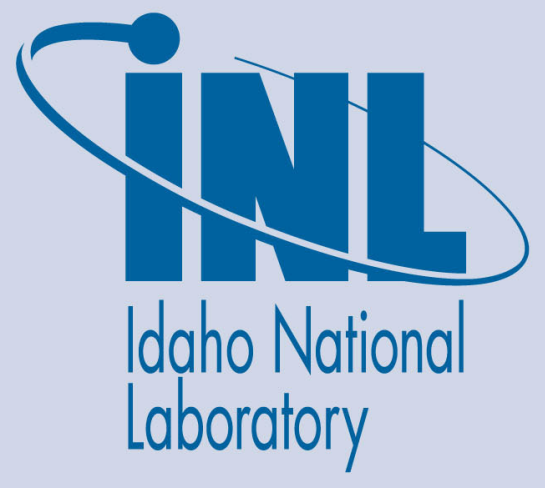

The INL is a U.S. Department of Energy National Laboratory operated by Battelle Energy Alliance 
INL/EXT-11-22339

\section{Western Energy Corridor - Energy Resource Report}

June 2011

\section{Idaho National Laboratory \\ Idaho Falls, Idaho 83415}

http://www.inl.gov

Prepared for the

U.S. Department of Energy

Office of Nuclear Energy

Under DOE Idaho Operations Office

Contract DE-AC07-05ID14517 


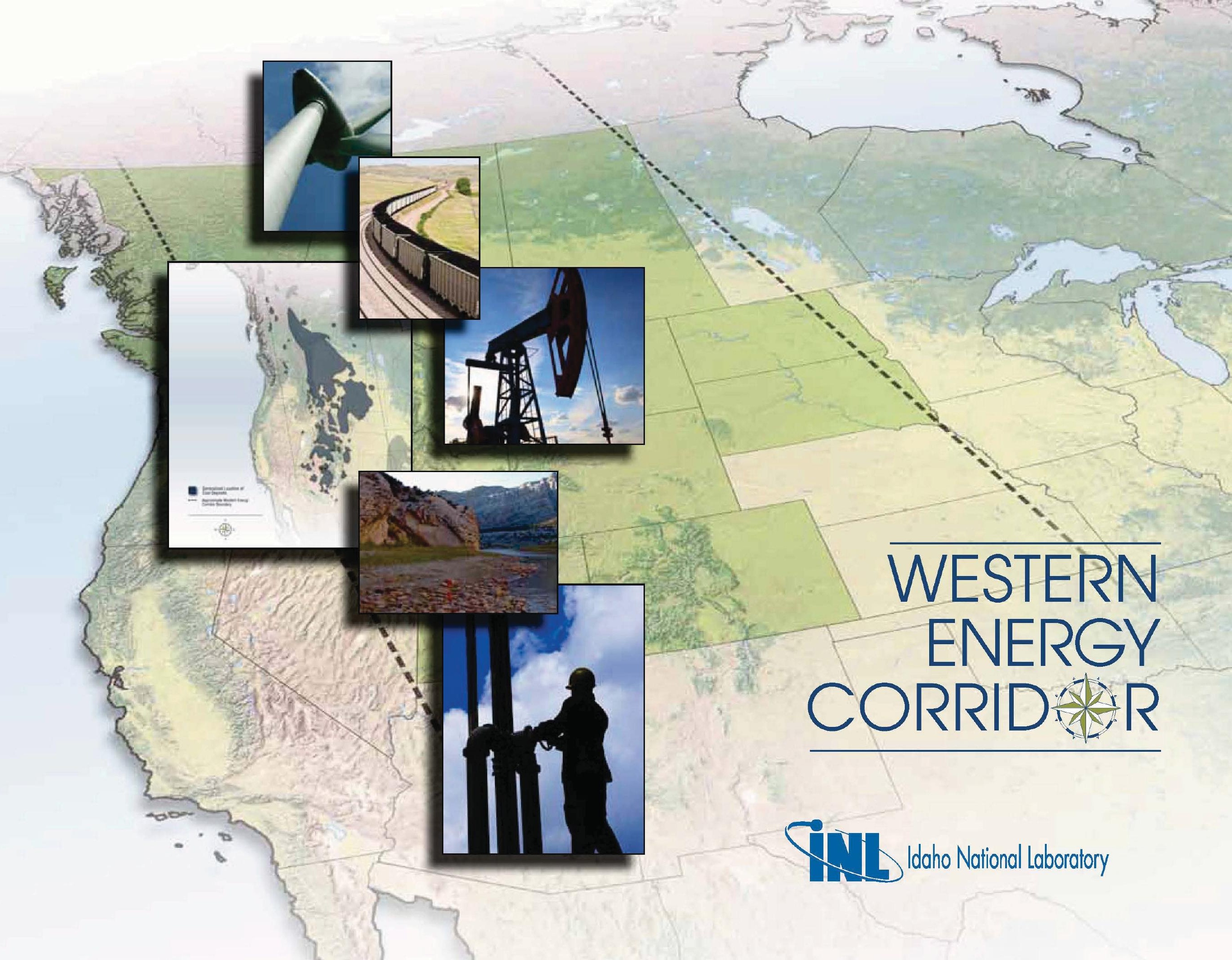




\section{Executive Summary}

$\mathrm{T}$

he energy resources concentrated along the Rocky Mountains and northern plains in Canada and the United States (U.S.) are world class, as measured by their diversity, magnitude, and longevity. This area, informally referred to as the Western Energy Corridor (WEC), is strategic to meeting the increasing energy demand in Canada, the U.S., and internationally. These energy resources, collectively, also provide a foundation for regional economic development, including a platform for moving the region's energy products up the value chain. To provide a foundation and stimulus for a bi-national regional dialogue, Idaho National Laboratory (INL) created this document with input from representatives of participating states and provinces. Further data was gathered from reliable internet and print sources and compiled to provide an overview of energy resources within the WEC.
In 2009 , WEC oil production was approximately 2.3 million barrels per day, with continued production growth anticipated from the Alberta oil sands and the Bakken Formation. Proven reserves, dominated by Alberta oil sands, currently place the region third in the world with approximately 170 billion barrels. Undeveloped potential oil resources within the WEC are estimated at over 4 trillion barrels (in-place). This includes oil shale reserves in the Green River Formation that spans parts of Wyoming, Colorado, and Utah.

Natural gas production in the WEC was approximately 10.5 trillion cubic feet (297 billion cubic meters) in 2009, which places the WEC third in natural gas production worldwide. Although conventional gas production is declining, new techniques and technological advances have enabled development of unconventional gas resources within the area (i.e., shale gas, tight gas, and coal bed methane), increasing overall natural gas production.
Coal production within the WEC was approximately 620 million short tons $(\sim 560$ million metric tons) with approximately 15 billion short tons (14 billion metric tons)

in recoverable reserves from active mines in 2009. WEC coal supplies much of the electricity production for Canada and the U.S., and the WEC hosts the largest coalproducing area (the Powder River Basin) in Canada and the U.S.

The WEC also contains several large river systems, which host a number of hydropower dams within and outside the WEC. British Columbia alone produced over 62 GWh of hydropower in 2009. Significant electrical generation potential remains untapped, especially in the north.

Other renewable energy resources, such as some of the greatest wind and bioenergy potential in Canada and the U.S., are available, but remain mostly untapped in the WEC. Efforts are underway to also develop geothermal and solar potential within the region.
Significant quantities of uranium found in the WEC supply a number of nuclear power plants internationally. Saskatchewan currently dominates uranium production and hosts the largest uranium mine in the world. The province contributed $18 \%$ of world production in 2009 , and is complemented by growing production south of the U.S.-Canada border.

Although large amounts of WEC raw energy resources are exported, these resources also contribute to local electricity and transportation fuel production. In 2009, electricity generation within the WEC was over 370 million MWh. Of this, more than $70 \%$ came from fossil energy plants (primarily coal and natural gas), approximately $24 \%$ from hydropower, and approximately $4 \%$ from other renewables with no contribution from nuclear energy.

Transportation fuels production in the WEC is primarily from oil refining, with small amounts of biofuels (i.e., biodiesel and ethanol). Plans are underway to build 
coal-to-liquids (CTL) and liquid natural gas (LNG) plants.

Energy delivery infrastructure is rapidly expanding. Oil and gas pipelines are both planned and built to provide access from newly developed fields such as the Bakken Formation to both traditional and nontraditional markets, including Asia. There are also plans to expand $\mathrm{CO}_{2}$ pipelines to enhance oil recovery and $\mathrm{CO}_{2}$ sequestration. New transmission lines are being planned and built to access and integrate more remote renewable energy sources, such as wind. Rail expansion continues to be essential to coal development. New rail lines could also support delivery of biomass feedstock as well as product from the Alberta oil sands and the Bakken Formation to new markets.

Sustainable energy development within the WEC relies on a number of interdependent factors. For example, energy development increasingly requires mitigating impacts on air, water, landscape, wildlife, and climate change. In addition, energy resources are critical for developing other natural resources in the region such as water, minerals, agricultural, and fertilizer. Also, technological innovation continues to play a pivotal role in accessing energy resources and mitigating environmental impacts. And energy demand and investment from Asia will continue to impact markets around the world.

The outlook for the WEC's economic prosperity is both timely and promising. Vast natural resources, strong commitment to economic development and a pledge to maintain quality of life place the WEC in a unique position to capitalize on its riches and become an international leader in energy resource development. Realizing the potential for development, distribution, and utilization of the WEC's energy resources will present both opportunities and challenges that will require more sophisticated and regionally integrated approaches, enabling policy, and continued investment.
WEC states and provinces are critical players in supplying the U.S. and Canada with energy resources this century and beyond. Given the importance of these resources there is an unprecedented opportunity for these states and provinces

\section{The Western Energy Corrid or contains a world-class}

\section{concentration of energy resources critical to ensuring}

\section{regional, U.S., Canadian, and international energy security}

and economic development. The states and provinces

within the Corridor have an unprecedented opportunity

\section{to collaborate with each other relative to challenges and}

\section{opportunities associated with developing these resources.}

to collaborate and more effectively address pertinent energy challenges and opportunities including policy, regulation, technology deployment, and regional economic development. Such an approach may be advantageous to these lowpopulation jurisdictions given their sometimes limited political influence at the national level. 


\section{Contents}

\section{Contents}

Acronyms............... 1

Introduction $\ldots \ldots \ldots \ldots \ldots, 2$

Fossil Energy Resources . . . . . . 4

Crude Oil . . . . . . . . . . . . 4

Conventional Crude Oil . . .5

Unconventional Oil

Resources...........5

Natural Gas . . . . . . . . . . 6

Conventional Natural

Gas ............... 7

Unconventional

Natural Gas. . . . . . . . . . . 7

Coal .................99

Renewable Energy Resources . . 12

Hydropower. . . . . . . . . . 12

Wind .................13

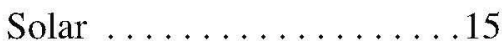

Biomass ..............16

Geothermal .............17

Tidal/Ocean Energy. . . . . . . 19

Uranium Resources . . . . . . . . . 20
Electricity Power Generation. . .22

Coal-Fired Electric Power

Generation............23

Natural Gas . . . . . . . . . . . 24

Renewable Energy. . . . . . . . 24

Nuclear Energy . . . . . . . . . 25

Liquid Fuels Production. . . . . . 26

Petroleum Refineries and

Upgraders ............26

Liquid Natural Gas

Facilities ............26

Coal-to-Liquids . . . . . . . . 27

Biofuels . . . . . . . . . . 27

WEC Energy Delivery . . . . . . .28

Electricity Transmission . . . .28

Natural Gas Pipelines . . . . . .29

Oil Pipelines ...........31

$\mathrm{CO}_{2}$ Pipelines ..........32

Rail ...............34

Energy and Environment . . . . . 36

Air $\ldots \ldots \ldots \ldots \ldots 36$

Water ................36

Landscapes and Wildlife . . . 37

Climate Change. . . . . . . . . 37
Energy-Resource Nexus. . . . . . 38

Agriculture ...........38

Fertilizer Production . . . . . .38

Water Resources . . . . . . . .39

Fossil Energy Development .39

Influences on WEC Energy

Development ............ 40

Demand . . . . . . . . . . . . 40

Energy Supply . . . . . . . . . 40

Energy \& Environment . . . . .41

Existing and Emerging

Export Markets ..........41

Price ... . . . . . . . . . . .41

Investment . . . . . . . . .41

Infrastructure . . . . . . . . 42

Technological Innovation . . .42

Research Assets . . . . . . . . . . .42

Summary ..............44

Appendix A-References . . . . 48

Appendix B-Tables . . . . . . . .57

Glossary . . . . . . . . . . . . . .73 


\section{Acronyms}

AECO Alberta Energy Company (trading symbol)

ARRA American Recovery and Reinvestment Act

ATR Advanced Test Reactor

bbl/d barrels per day

BCF billion cubic feet

BCFD billion cubic feet per day

$\mathrm{BDt} / \mathrm{yr}$ bone dry metric tonnes per year

BOE barrel of oil equivalent

BP British Petroleum

Bst billion short tons

CAPP Canadian Association of Petroleum Producers

CBM coal bed methane

CCEI Canadian Center for Energy Information

CCS carbon capture and sequestration

CEA Canadian Electricity Association

CHA Canadian Hydropower Association

$\mathrm{CO}_{2}$ carbon dioxide

CPV concentrator photovoltaic
CSUG Canadian Society for Unconventional Gas

CTL coal-to-liquids

DOE Department of Energy

EEI Edison Electric Institute

EIA Energy Information Administration

EOR enhanced oil recovery

EPA Environmental Protection Agency

EPAct Energy Policy Act

FERC Federal Energy Regulatory Commission

GIS geographic information system

GW gigawatt

GWh gigawatt-hour

IEA International Energy Agency

IGCC integrated gasification combined cycle

IJHD International Journal of Hydropower and Dams

INL Idaho National Laboratory

IPCC Intergovernmental Panel on Climate Change
IPPBC Independent Power Producers of British Columbia

ISCG in situ coal gasification

$\mathrm{kWh} / \mathrm{m}^{2}$ kilowatt-hours per square meter

LNG liquified natural gas

MMCFD million cubic feet per day

MMst million short tons

MRO Midwest Reliability Organization

MW megawatt

MWh megawatt-hour

NERC North American Electric Reliability Corporation

NETL National Energy Technology Laboratory

NPP nuclear power plant

NYMEX New York Mercantile Exchange (trade symbol)

R\&D research and development

RMOTC Rocky Mountain Oilfield Testing Center

RPS renewable portfolio standard
SAGD steam-assisted gravity drainage

TCF trillion cubic feet

$\mathrm{U}_{3} \mathrm{O}_{8} \quad$ triuranium octoxide

UHOP Utah Heavy Oil Program

USGS United States Geological Survey

WCI Western Climate Initiative

WEC Western Energy Corridor

WECC Western Electricity Coordinating Council

WGA Western Governors' Association 


\section{Introduction}

T Torld-class energy resources strategic to North American energy security and economic development are concentrated along the Rocky Mountains and northern plains in Canada and the U.S. This region is informally referred to as the Western Energy Corridor [WEC; Figure 1]. The fossil energy resources in this region are rivaled in only two other regions, and the proven uranium reserves are among the world's largest. Renewable resources including wind power, hydropower, bioenergy, geothermal energy, and solar energy are also concentrated in this region. Substantial existing and planned energy infrastructure, including refineries, pipelines, electrical transmission lines, and rail lines provide access to these resources and facilitate their development.
As world energy demand increases in the 21st century, the U.S., Canada, and likely Asia will become more dependent upon WEC resources. Development, distribution, and utilization of these regional resources will present both opportunities and challenges that will require more sophisticated and integrated approaches. Strategic energy development and stewardship will be required to ensure energy security, regional economic development, and quality of life throughout the region. In addition, the enormous quantity of energy resources in the region provides a foundation for attracting valueadded industrial enterprises.

The states and provinces hosting these resources can build a greater, more prosperous and sustainable future based on their supplies. To stimulate a bi-national regional dialogue on the current and future

Figure 1.

Approximate boundary of the WEC and outline of participating provinces and states. [M1]

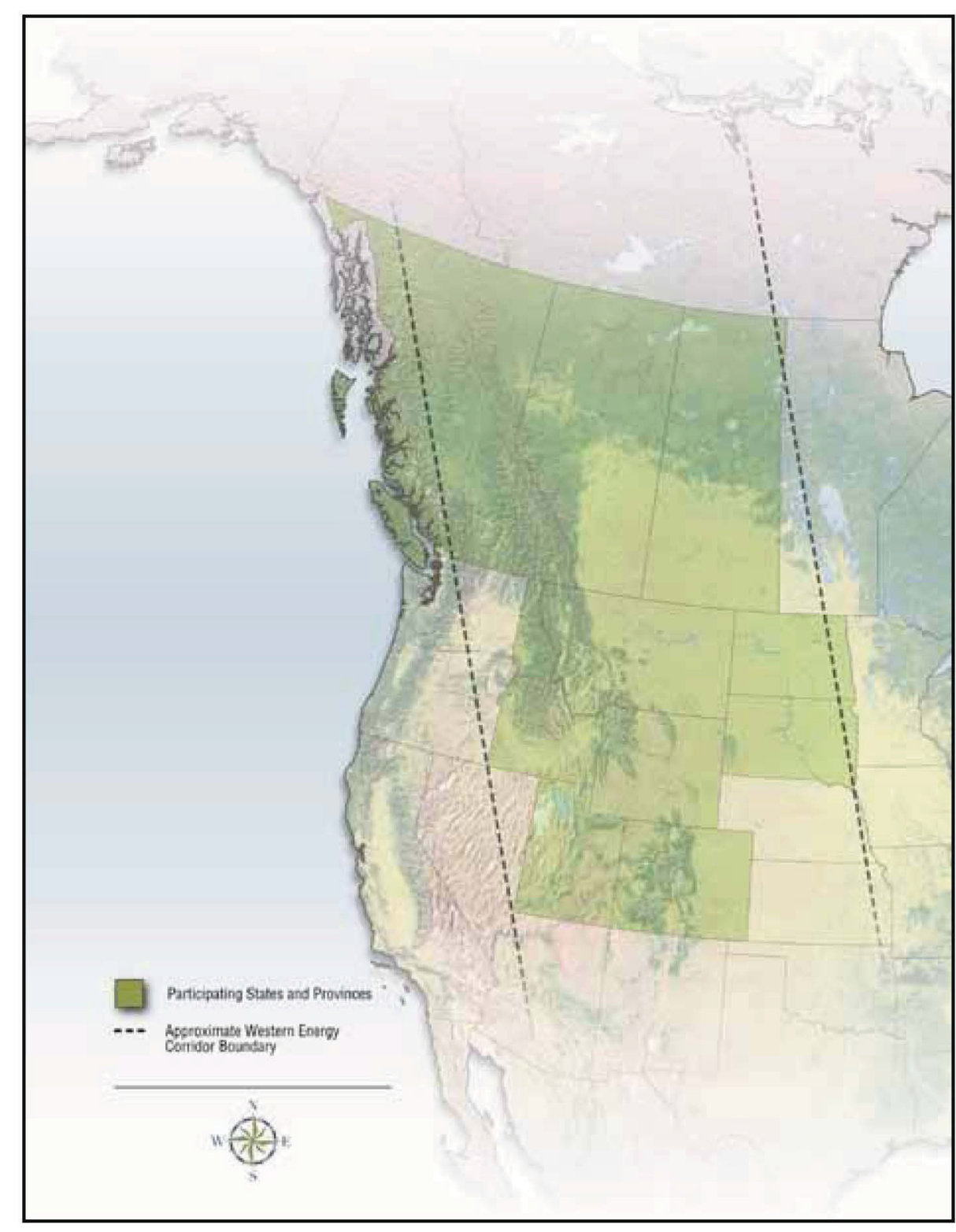




\section{Introduction}

use of these resources, Governor Brian Schweitzer of Montana and Premier Brad Wall of Saskatchewan solicited interest from several regional governors and premiers to engage further on this topic. This group subsequently determined that it requires additional information about the regional resources to foster a productive dialogue. To address this need, Gov. Schweitzer, on behalf of a number of incumbent governors and premiers, requested that INL prepare a inventory of energy resources within the WEC.

With the assistance of representatives from participating states and provinces, INL prepared this document highlighting general energy resource information, conversion methods into marketable forms, and infrastructure required to deliver it to users. A select number of affiliated topics have been included to facilitate the dialogue around interdependent aspects of developing these resources. These topics, whether technical, social, or economic, must rely on a sound strategy with common goals and policies that promote a balance between environmentally-sound development, energy security, and a competitive industrial base. This document provides a foundation and framework for governors and premiers to focus their dialogue on leveraging each other's resources and capabilities within the bi-national WEC region. provinces, and even Canadian territories can potentially be added in the future, which would increase to the collective energy resource wealth of the WEC.

Finally, the energy sector marketplace is dynamic, meaning information can quickly become obsolete and need to be updated as research and dialogues progress.

\section{Strategic energy development and resource stewardship are}

\section{paramount to ensure energy security, regional economic}

\section{development, and quality of life throughout the region.}

The WEC's boundary, as currently outlined for this discussion, is approximate, designed to encourage dialogue built around a novel geographic perspective, and should be considered preliminary. This document focuses on addressing the following states and provinces: Alberta, British Columbia, Colorado, Idaho, Montana, North Dakota, Saskatchewan, South Dakota, Utah, and Wyoming. Other states,
This document provides the latest available information at the time the research was done, which has been extracted from public sources with references provided. Maps included in the document typically represent compilations of maps produced at various levels of detail and should be considered qualitative graphical overviews. 


\section{Fossil Energy Resources}

ubstantial crude oil, natural gas, and coal resources exist throughout the WEC. Crude oil contributes substantially to U.S. and Canadian transportation needs, while natural gas and coal contribute substantially to electricity production. Both conventional and unconventional WEC oil and gas resources are discussed below. Oil and gas that can be recovered through methods in use for decades are considered "conventional" resources. However, fossil resources that require recently developed and innovative recovery technologies are deemed "unconventional" resources. As the "easier-to-get" conventional resources are depleted, unconventional resources will make up a greater proportion of the oil and gas portfolio in the WEC.

\section{Crude 0il}

Conventional and unconventional oil reservoirs exist throughout the WEC [Figure 2]. Combined proven reserves of both conventional and unconventional oil are estimated to be 175 billion barrels, dominated by Alberta oil sands at approximately 170 billion barrels and the province's conventional crude reserves of approximately 1.4 billion barrels [1]. This estimate places Alberta's reserves (and thus the WEC) third behind Venezuela (211 billion barrels) and Saudi Arabia (267 billion barrels) in proven oil reserves [2; Figure 3]. Proven reserves provide a conservative estimate of the amount of oil (or gas) that will be produced. Current overall crude oil production from the region is approximately 2.3 million barrels per day, $36 \%$ of which comes from conventional sources and $64 \%$ from the Alberta oil sands [Table 1].

Figure 2. WEC crude oil reservoirs. [M2]

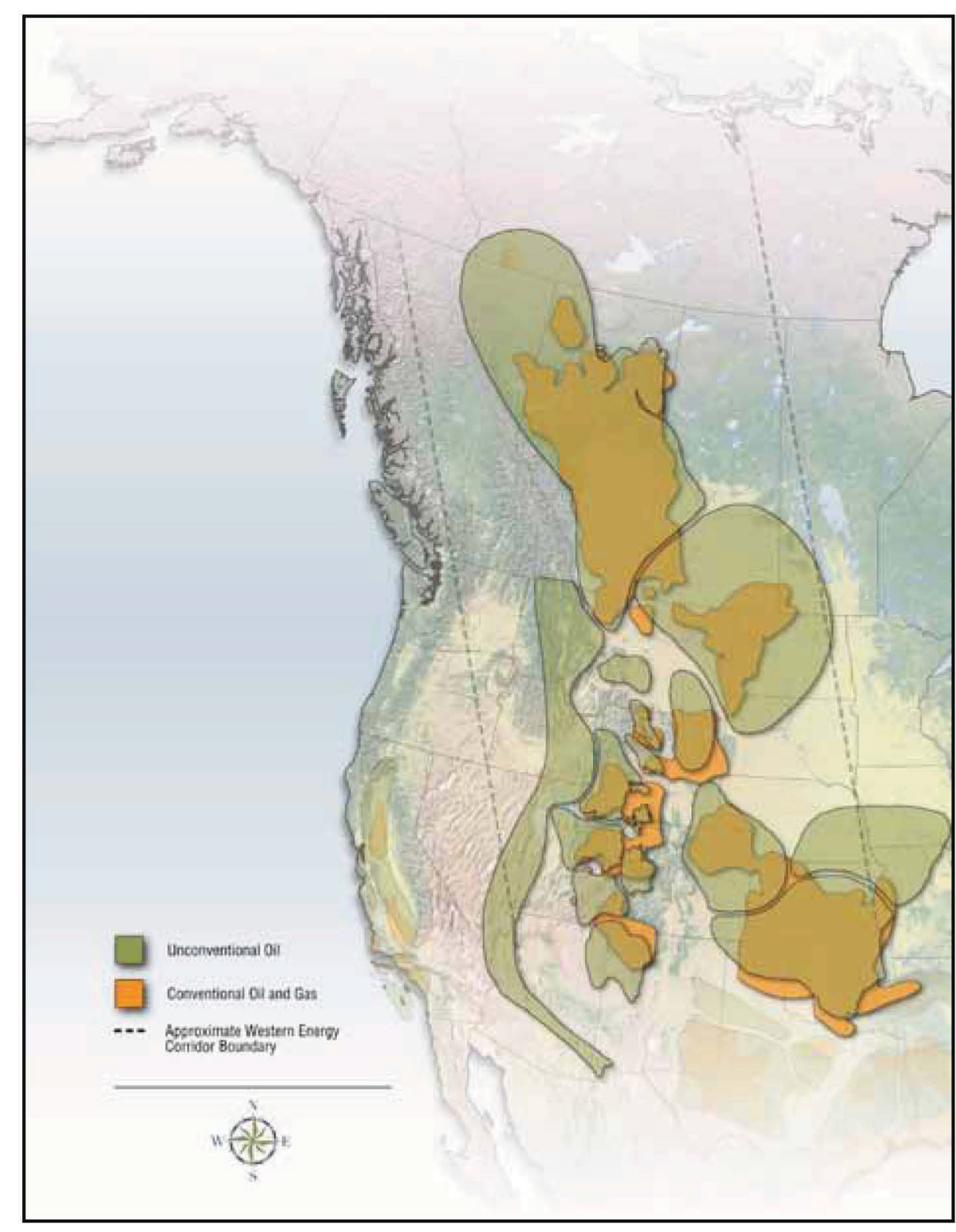




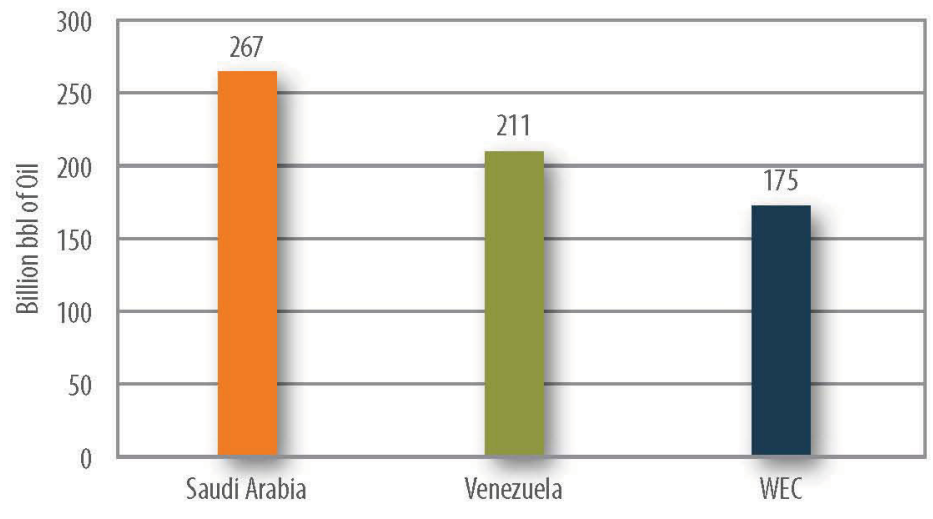

Figure 3.

Conventional and unconventional proven crude oil resources.

\section{Conventional Crude 0il}

Some of the larger conventional oil reserves are located in Alberta, Saskatchewan, and North Dakota [Table 2]. Collectively, the WEC is estimated to contain proven reserves of approximately 5.4 billion barrels as of 2009 (excludes oil sands), which accounts for about $21 \%$ of total Canada/U.S. conventional reserves. Production of conventional crude oil within the WEC is just under 1.3 million barrels per day, based on 2009 data, which is about $35 \%$ of total U.S./Canadian production in 2009 [Table 1]. tion, the Cardium Formation in Alberta is generating significant interest given the potential to apply fracturing stimulation techniques, similar to those employed in the Bakken, which may dramatically increase oil recovery in these fields. There are also emerging opportunities within the Viking Formation in Alberta and Shaunavon Formation in Saskatchewan.

\section{Unconventional Oil Resources}

\section{Oil Sands}

In 2009, proven bitumen oil sands reserves within the WEC were approximately 170 billion barrels. Ultimate recoverable reserve estimates for this Alberta resource are as high as 315 billion barrels. Estimates of Alberta's in-place resource are about 1.8 trillion barrels of bitumen [Figure 4]. It is estimated that the Grosmont Carbonate Deposit contains approximately 406 billion barrels of bitumen resource in place and is the second largest bitumenbearing formation in Alberta [6] Technologies and techniques to recover bitumen from carbonates are not finalized, and commercial development of this resource is still in its infancy. As a result, reserve estimates for the Grosmont Deposit have not been released because there are no commercial projects operating in the area. In 2009 , total bitumen production in Alberta was approximately 1.5 million barrels per day [7]. Utah's in-place bitumen reserves are between 12 and 19 billion barrels [8].

In Place: $1,800 \mathrm{~B}$ bbl

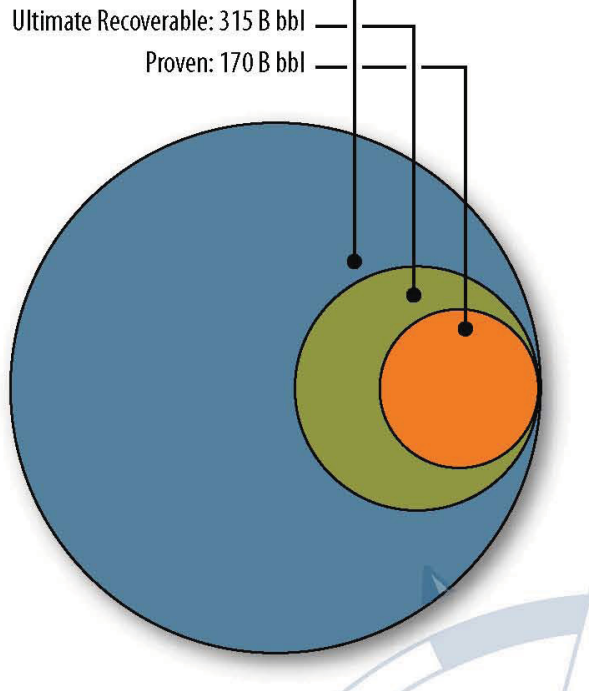

Figure 4.

Alberta's unconventional oil reserves from oil sands. 


\section{Oil Shale}

Oil shale is another immense yet relatively undeveloped WEC resource. Approximately $70 \%$ of the world's oil shale is found in the Green River Formation in Colorado, Utah, and Wyoming - nearly 3.15 trillion barrels in place [Table 3; Figure 5]. Oil shale deposits also exist in Saskatchewan and British Columbia. However, these deposits are not well characterized and are considered small relative to the Green River Formation resource.

Oil shale is rock containing relatively high amounts of organic matter known as kerogen. When kerogen is heated, it can be converted to petroleum products that can be upgraded and refined. The oil shale may be treated in place (in-situ retort) or in a surface facility (ex-situ retort). Not all of this resource, however, is recoverable. Estimates of the recoverable fraction range from $45-80 \%$ for mining operations. There are currently no such estimates for in-situ methods [9]. Assuming a recoverable factor of $50 \%$ (near the lower end for room-and-pillar mining)yields a recoverable resource estimate of 1.58 trillion barrels of oil, which is close to the 1.82 trillion barrels suggested by the Department of Energy [10]. Estimates of recoverable oil shale resource are $17-33 \%$ greater than current estimates of world-wide proven conventional oil resources.

\section{Heavy 0il}

Heavy and extra heavy oils are unconventional sources that have lost their lighter oil fractions, leaving

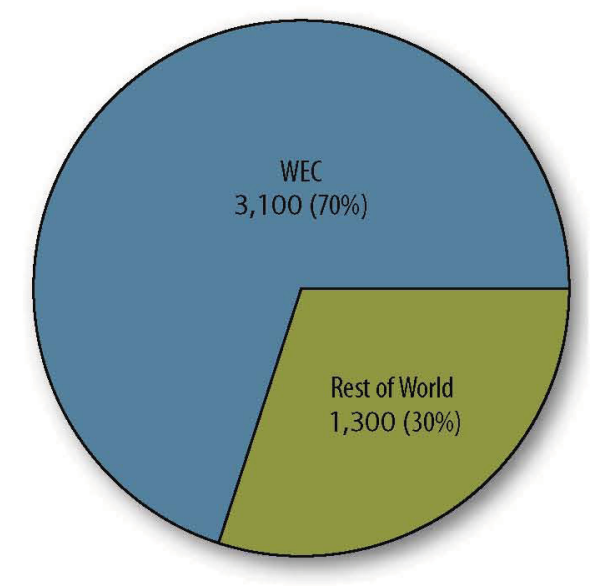

Figure 5.

In-place oil reserves from shale (billion bbl of oil). behind a much heavier crude oil [11]. Heavy/extra heavy oils have higher densities and viscosities than light oil, but their densities and viscosities are lower than those of bitumen. Approximately 1.25 billion barrels are found in the U.S. portion of the WEC, primarily in Wyoming. Alberta and Saskatchewan have significant resources of heavy oil, primarily in their carbonate formations; Wyoming and the rest of the WEC have relatively minor amounts. The WEC's total heavy oil reserves are estimated at 550 billion barrels [Table 4].

\section{Natural Gas}

The WEC contains abundant conventional natural gas resources including more than $38 \%$ of the combined remaining reserves of Canada and the U.S. [Table 5]. In addition, the WEC has vast unconventional gas resources including coalbed methane (CBM), shale gas, and tight gas. The relative importance of these reserves is clearly illustrated by the U.S. Energy Information Administration's (EIA's) estimates for increased unconven- tional production and declining onshore conventional production in the U.S. through 2035 [Figure 3]. Shale gas will be the largest contributor to the projected increase in gas production. Tight gas and CBM will contribute significant fractions to the projected total $[12$; Figure 6].

Total reserves of conventional and unconventional natural gas in the WEC are at least 680 trillion cubic feet (TCF), primarily as tight gas and coal bed methane. This is equivalent to more than 64 years of production, based on current production rates. Alberta, Wyoming, and Colorado rank first through third in the WEC. Almost 98\% of Canada's proven conventional natural gas is located within the WEC [Table 5]. 
WEC natural gas production estimated in 2009 was approximately 10.5 TCF per year, which is approximately one third of the combined U.S. and Canadian production, and almost $8 \%$ of the world production. Alberta and Wyoming

\section{Natural gas production in the WEC is approximately 10.5}

TCF per year, which places it third behind Russia and the

\section{U.S. in world ranking}

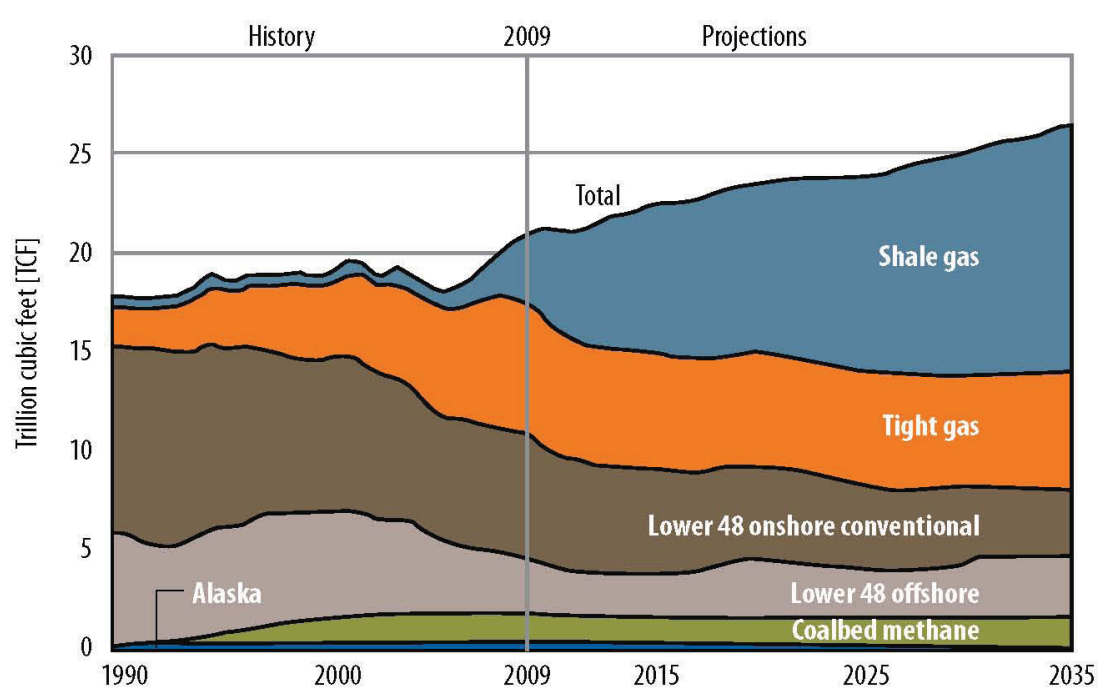

\section{Figure 6.}

U.S. natural gas production by source, 1990-2035. [12]
In 2009, 57.4 billion cubic feet per day (BCFD), or $85 \%$, of natural gas consumed in the U.S. came from domestic sources. More than $10 \%$ came from Canada, and about $5 \%$ came from international sources in the form of liquefied natural gas. Nearly $59 \%$ of Canada's production is exported to the U.S., with Alberta alone exporting over $71 \%$ of that (approximately 1.85 TCF) in 2009 [13]. Figure 8 shows the locations of these reserves.

\section{Conventional Natural Gas}

Established conventional natural gas reserves in the WEC exceed 127 TCF - nearly $40 \%$ of the remaining established reserve totals for Canada and the U.S. [Table 5; Figure 7].

\section{Unconventional Natural Gas}

The growing amount of accessible unconventional gas resources will increase natural gas production in both the WEC and the rest of North America. Shale gas is expected to be the most significant contributor to domestic production during the next 25 years due to enormous North American quantities.

\section{Coalbed Methane}

Nearly $63 \%$ of the U.S. and Canada's total CBM reserves are located in the WEC. Approximately $44 \%$ of established U.S. reserves are located in Colorado and Wyoming, while $64 \%$ of established Cana-

Colorado and Wyoming $54 \%$

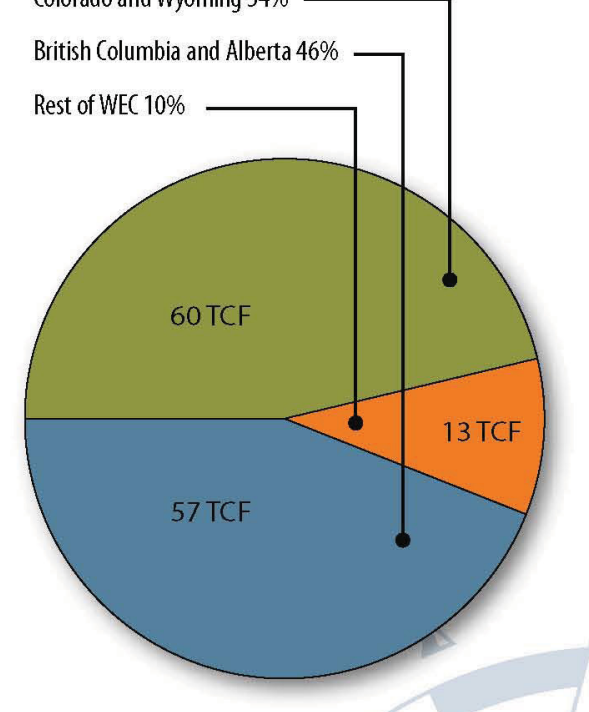

Figure 7.

Established (conventional) reserves: 127 TCF. 


\section{Fossil Energy Resources}

dian reserves are found in Alberta and British Columbia [Table 7].

Production of CBM in the WEC is expected to grow in the future.

\section{Tight Gas}

Tight gas formations are distributed throughout the WEC. Estimates of tight gas sands for individual states are not readily available, but a recoverable U.S. reserve estimate is 379 TCF [14]. In-place resources of tight gas in British Columbia are greater than $300 \mathrm{TCF}$ [15].

\section{Shale Gas}

Shale gas is extracted from true shales and mudstones, by far the most common rocks in sedimentary basins. The gas content in these rocks varies widely, but it is likely that important shale gas discoveries will be made in the WEC. New assessments of the technically recoverable North American shale gas in the past few years have substantially increased confidence that the domestic natural gas supply will be sufficient to meet growing demand for decades to come. For example, Colorado, Montana, and
North Dakota have proven reserves of $510 \mathrm{BCF}$. This value is less than $1 \%$ of the U.S. proven reserve of shale gas [Table 8]. In 2009, shale gas production in these states was 33 BCF. Estimates of the amount of gas in place will almost certainly increase as previously neglected shale formations are evaluated. The amount of gas that ultimately will be recovered may depend more on improvements in extraction technology, market prices, and government regulation than the amount of gas in place. At this stage, proven reserves are a conservative estimate of the amount of gas that can be recovered, and technically recoverable resource estimates are speculative.

Figure 8. WEC natural gas reservoirs. [M3]

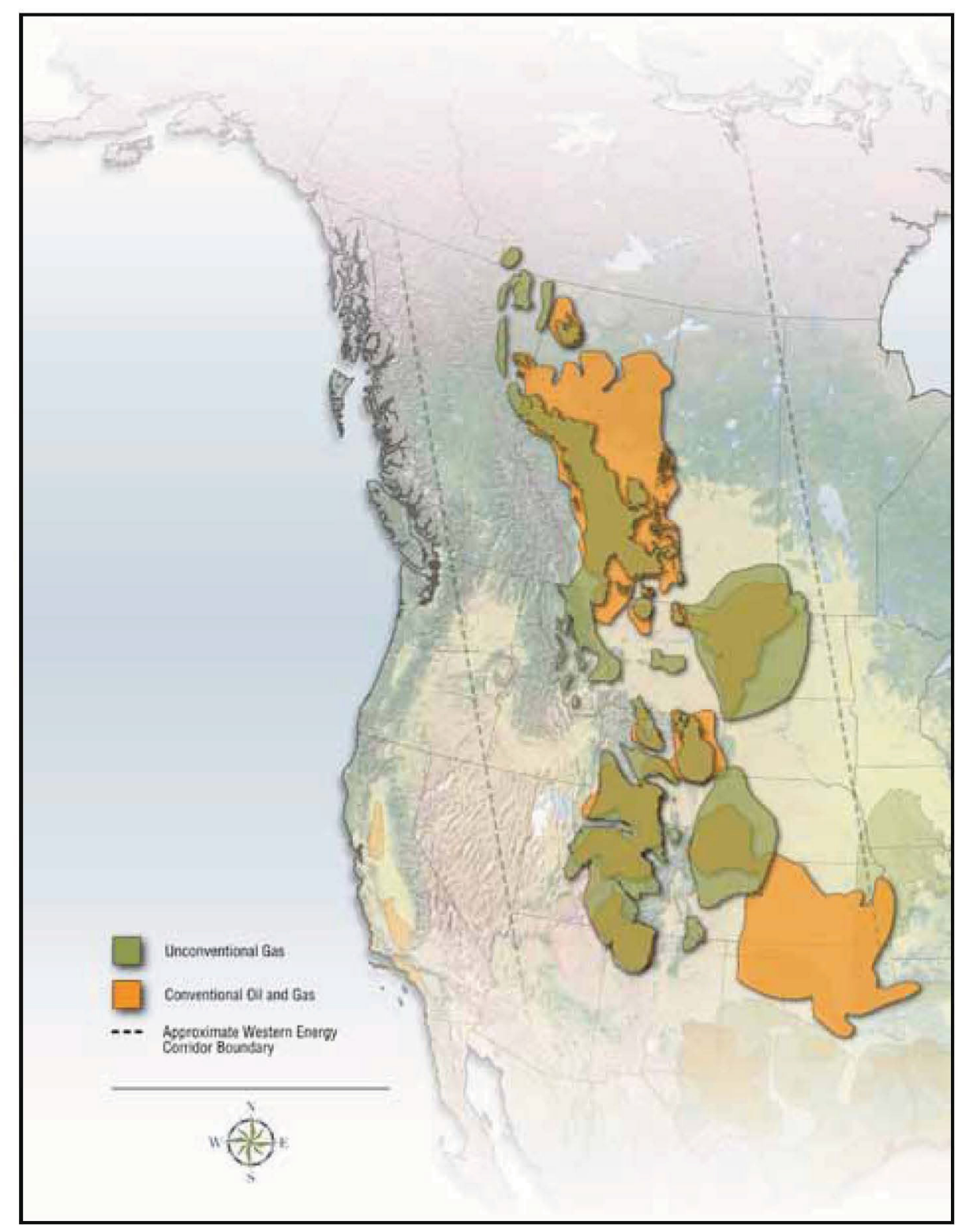




\section{Fossil Energy Resources}

Canadian activity in shale gas is primarily focused on the Montney and Horn River Basin plays of northeast British Columbia, which has recoverable reserves of 69 and $132 \mathrm{TCF}$, respectively. The Horn River and Cordova Embayment alone account for almost two thirds of currently defined shale gas in Canada. Another Canadian play, the Colorado Group in Alberta and Saskatchewan, has 61 TCF of recoverable reserves and may be Canada's largest in-place reserve at $408 \mathrm{TCF}$. Note that there is an estimated $43.4 \mathrm{TCF}$ of natural gas reserves in offshore British Columbia; however, a federal moratorium on drilling currently prevents any production activity there $[16,17]$.

\section{Coal}

Coal supplies $45 \%$ of all U.S. electricity and less than $20 \%$ of Canada's electricity [18]. More than 30 states receive coal from Wyoming, and several midwestern and southern states are highly or entirely dependent on Wyoming's coal [19].Export of coking coal from WEC jurisdictions to Asia, primarily for use in steel production, is increasing. Alberta and British Columbia comprise one of the largest metallurgical coal suppliers in the world and export significant amounts of coal to Asia [20]. Wyoming and Montana are now exploring ways to access shipping terminals along the U.S. West Coast to do the same.
The WEC's vast coal resources [Figure 11] range in grade from lignite to anthracite. Recoverable reserves (from active mines) in the WEC include 15 billion short tons (around 14 billion metric tons) [Figure 9], approximately $63 \%$ of the total U.S. and Canadian recoverable coal reserves. More than $54 \%$ of the recoverable U.S. coal reserves and approximately $84 \%$ of
Canada's recoverable reserves are located in the WEC [Table 9].

In 2009 , the WEC produced approximately 620 million short tons (560 million metric tons) of coal, which is about $8.2 \%$ of world production and about $54 \%$ of the combined total production of the U.S. and Canada [Table 10; Figure 10]. Of the WEC states, Wyoming

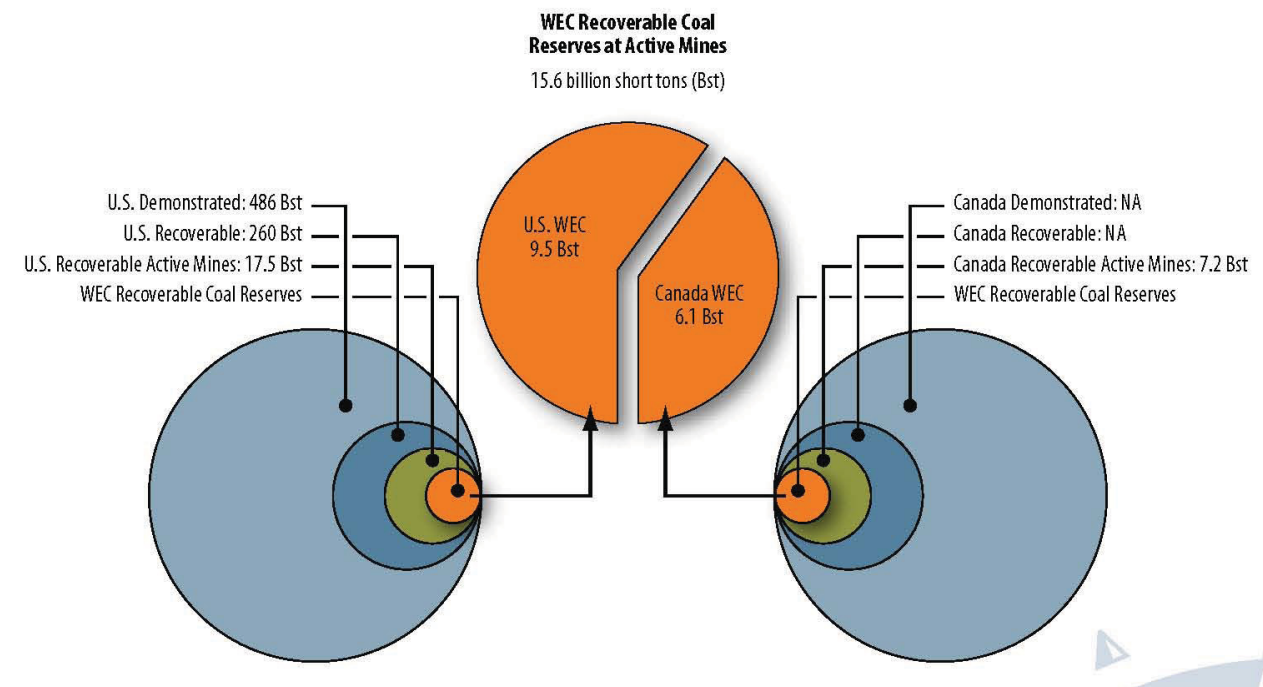

Figure 9.

The sum of recoverable U.S. and Canada coal resources. 


\section{Fossil Energy Resources}

maintains the greatest production at 431 million short tons (about 390 million metric tons) in 2009. The Powder River Basin, most of which lies in northeastern Wyoming, is the largest coal producing region in both the WEC and the U.S. The region accounts for more than $42 \%$ of all coal mined in the U.S. Approximately $51 \%$ of U.S. coal production [21] and nearly all Canadian coal production occurs in WEC states and provinces [22].

An example of a novel approach to coal-based electrical generation

\section{For the next 3 to 4 decades, coal will continue to play a}

\section{foundational role within North America, greatly contributing}

to the generation of relatively low-priced, base-load electricity.

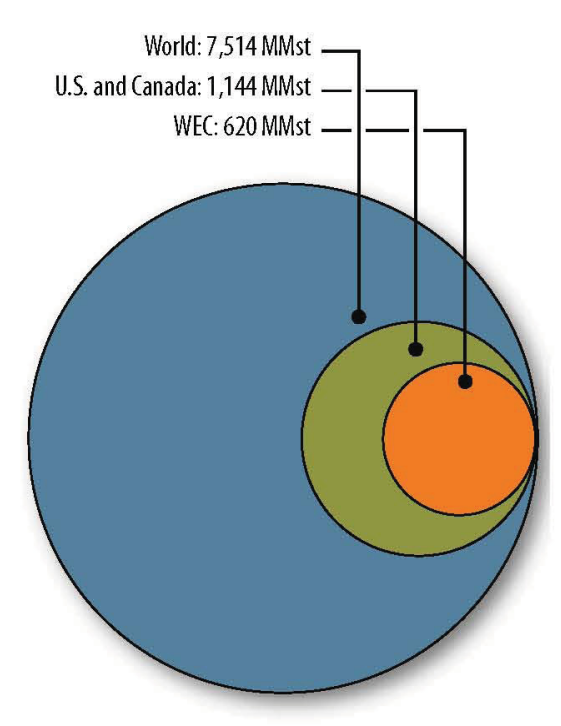

Figure 10.

Coal production.
Figure 11.

Distribution of coal resources in the WEC. [M4]

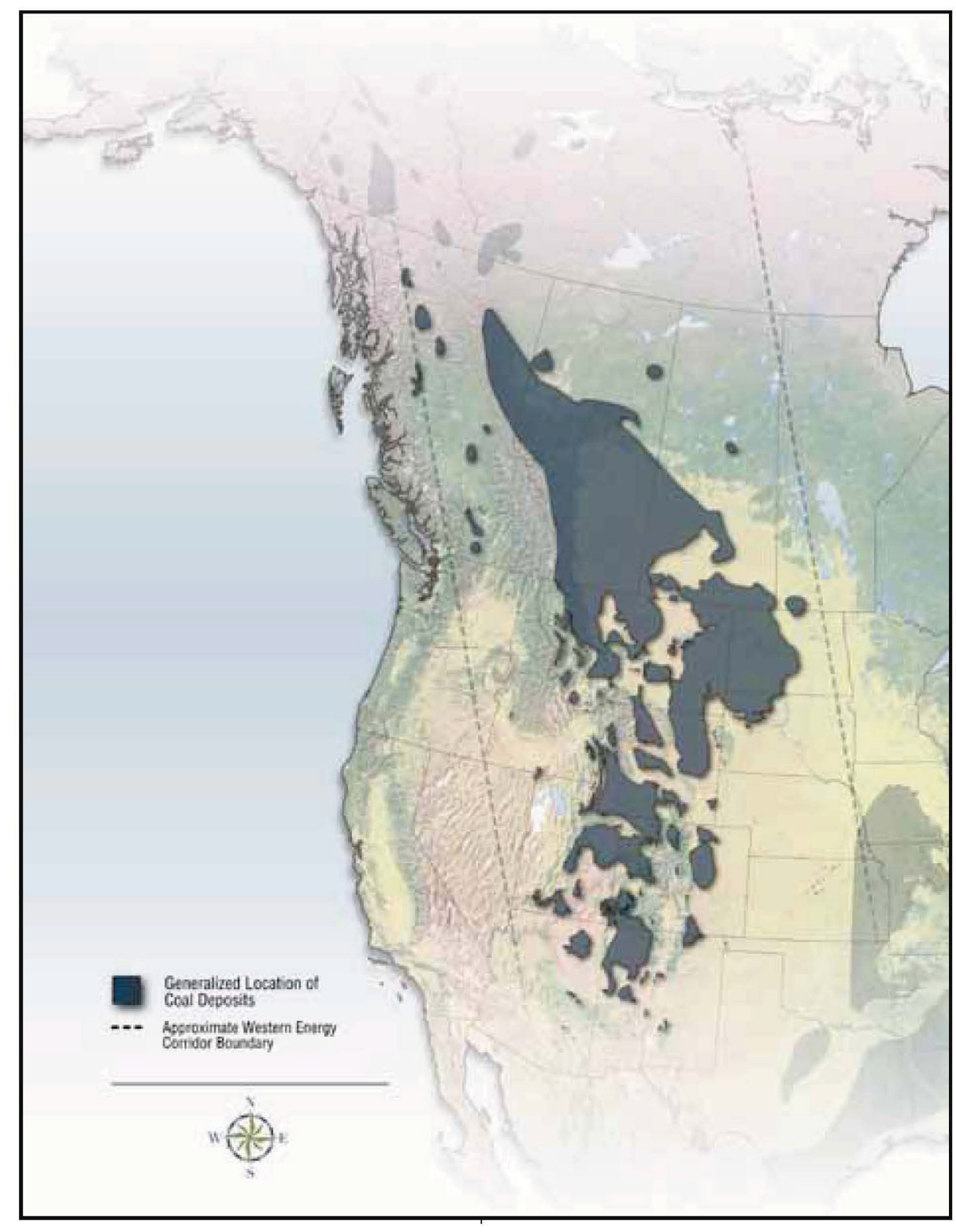




\section{Fossil Energy Resources}

within the WEC is found as part of the Swan Hills project in Alberta.

The project will use an in-situ coal gasification (ISCG) process to access coal seams that are considered too deep to mine. The coal seams, located about 1,400 meters $(4,593$ feet) beneath the earth's surface, will be accessed through wells that are similar to conventional oil and gas wells. The ISCG wells will be used to convert the coal underground in its original seam into syngas. The syngas will be piped to the Whitecourt area to fuel new highefficiency, combined-cycle power generation for Alberta's electricity market, providing about $300 \mathrm{MW}$ of generation capacity [23].

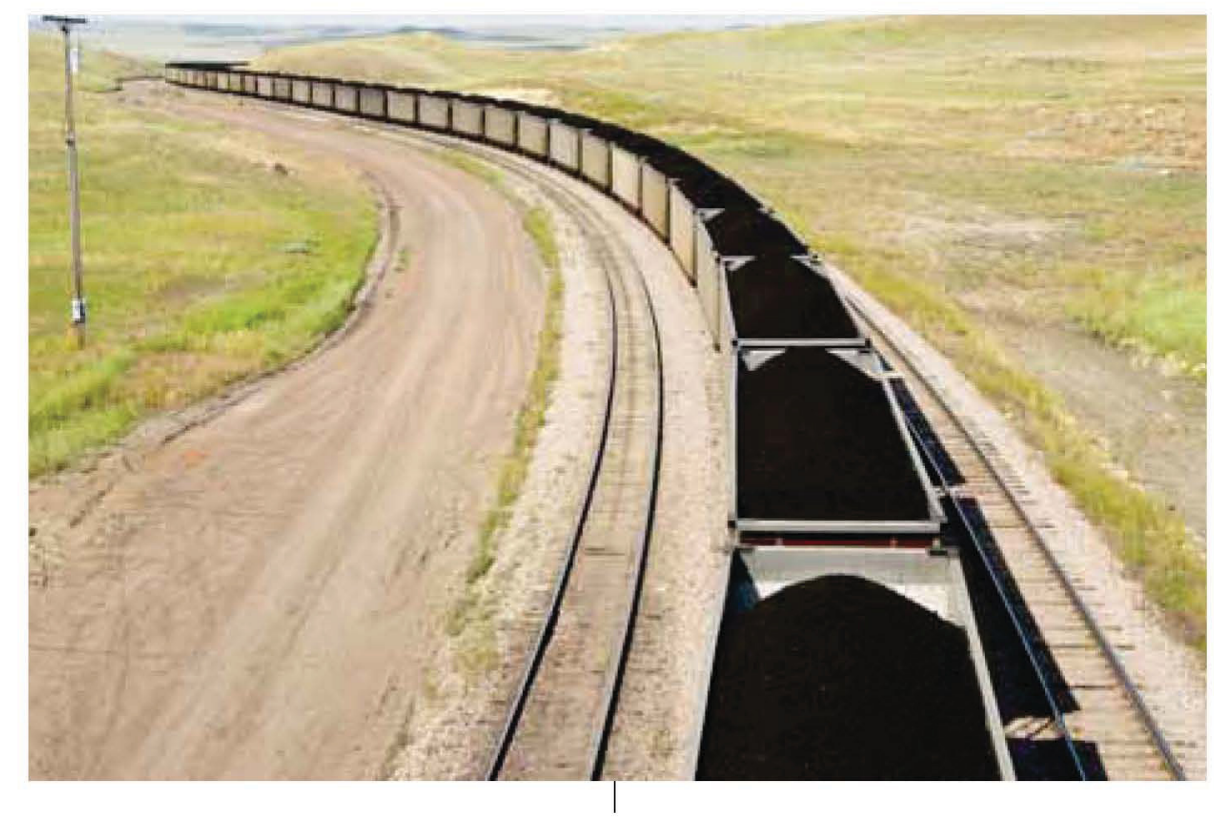

More than 30 states receive coal from Wyoming, and several Midwestern and southern states are highly or entirely dependent on Wyoming's coal supply 


\section{Renewable Energy Resources}

$\mathrm{S}$ ignificant renewable energy resources in the WEC include energy derived from water (including rivers and ocean current/tidal/wave), wind, sun, geothermal, and biomass. Renewable energy sources generate electricity, provide heating, and produce transportation fuels, as well as provide feedstocks for a host of other products from methane to plastics. Renewable energy sources can lessen dependence on imported and non renewable resources, and many can help reduce the environmental impacts of overall energy generation. The Western Renewable Energy Zones (WREZ) initiative, a collaboration between the Western Governors' Association and the U.S. DOE (along with other stakeholders) is designed to facilitate development and delivery of renewable energy within the Western Interconnect and has a wealth of renewable energy information.

\section{Hydropower}

Extensive river systems in the WEC make hydropower a significant resource for electricity generation. These systems consist of several major North American rivers [Figure 12], including the North Saskatchewan, Peace, Athabasca, Slave, Missouri, Columbia, Snake, Mackenzie, and Colorado rivers, whose headwaters are contained within the WEC. In the WEC, over 88,000 GWh of electricity was generated from hydropower in 2009, which represents approximately $24 \%$ of the WEC's total electricity generation that year from all sources. This power was produced by 374 hydropower plants having a total installed capacity of $21 \mathrm{GW}$. In British Columbia, the greatest annual hydropower generation so far, 64,000 GWh occurred in 2007 [24]. Hydropower generation in British Columbia, Idaho, and South

Figure 12. Major waterways in the WEC. [M5]

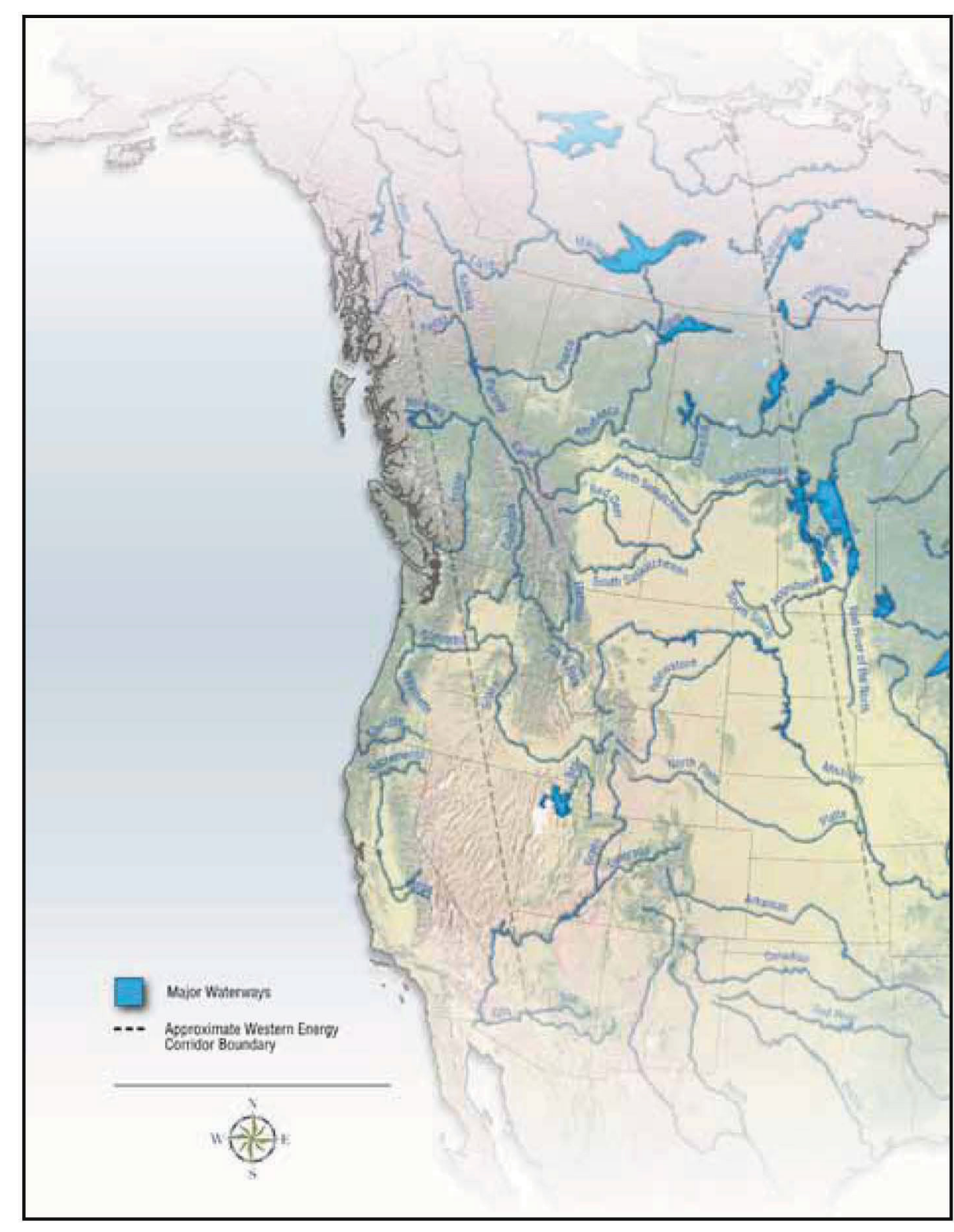




\section{Renewable Einergy Resources}

Dakota produce large percentages of total in-state/province electricity generation [Table 11].

The WEC has approximately 60 GW of untapped hydropower potential capacity, which is three times the current installed capacity and translates to a potential of over $265,000 \mathrm{GWh}$ of additional annual electricity generation. The majority of this potential lies in the north side of the WEC. Although full hydropower potential may never be realized, state/province generation potentials range from $160 \%$ (Montana) to $3800 \%$ (Alberta) above their 2009 generation [Table 11]. A significant portion of the additional hydropower resource would come from small facilities and micro-hydro and would require new transmission to successfully harvest the resource, especially in British Columbia.

Several planned projects - the majority in northern Canada would increase the WEC's hydropower capacity. For example, British Columbia plans to install two 500-MW generating units into existing dam infrastructure at the Mica Generating Station [24]. According to a recent report [25], major hydro projects in Alberta may be developed in the next 30 years and could capture almost $20 \%$ of Alberta's over 53,000 GWh hydropower potential per year. Also, $28 \%$ of proposed pumped storage projects in the U.S. are sited in WEC states [26].

\section{Wind}

Wind energy is abundant throughout the WEC [Figure 13] with a total wind power potential of over 3,700 GW. Within the Corridor, Montana leads in wind energy production potential at $944 \mathrm{GW}$, followed closely by South Dakota and North Dakota [Table 12]. North Dakota, Wyoming, and Colorado lead the WEC in installed wind generation. Although the WEC has very high wind power potential,

Figure 13.

Wind energy potential in the WEC.

[M6]

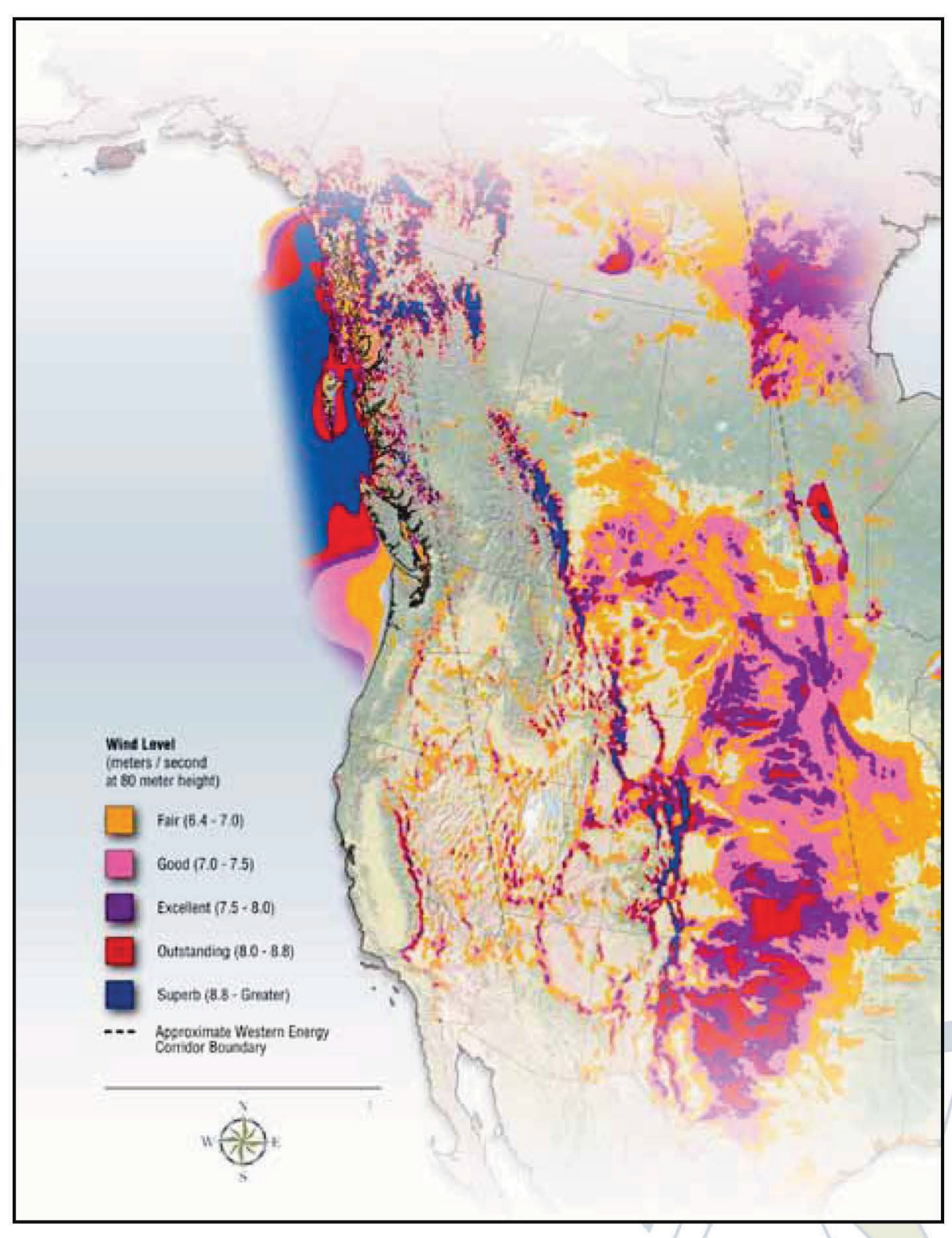


the realized potential is relatively low. For example, despite Montana's high generation potential, installed capacity was only $375 \mathrm{MW}$ as of 2009 [Table 12]; however, tops and the remote northwest of British Columbia. For areas that could be reasonably developed, the major constraint is transmission.

The low capacity factor results in
MW of wind power capacity is from on-shore operations.

\section{Wind, geothermal, solar, and ocean/tidal continue to grow and offer a promising future, even more so when used in combination with other energy forms - hybrid energy systems.}

significant increases in installed capacity in Alberta and Montana will be feasible with completion of the new Montana Alberta Tie Limited transmission line.

The intermittent nature of wind makes integration into the electrical grid challenging if transmission, firming resources, and distribution of wind resources are insufficient or unavailable This challenge becomes more severe as wind capacity increases relative to other power sources. The major reason that realized wind potential is low is that much of the wind resource is located in areas that cannot be developed or are not easily accessible, such as mountain

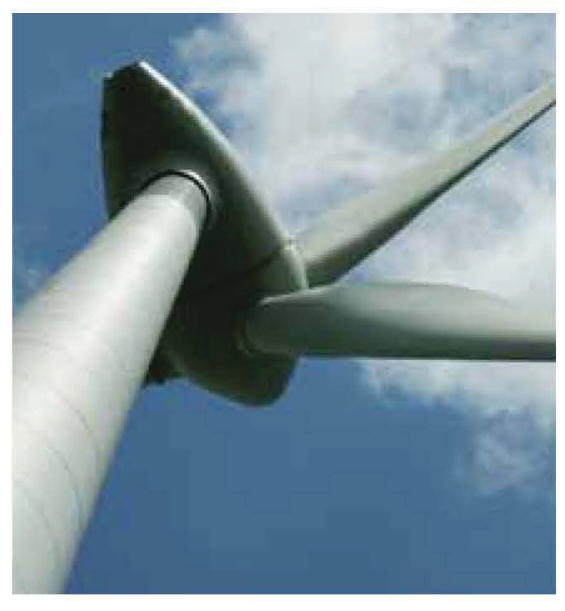

a high capital cost per unit output, although the fuel (wind) is free. The first off-shore project, with a potential wind power capacity of $396 \mathrm{MW}$, just received federal approval in British Columbia [27], but the province's existing 248
Wind power generation is increasing at a rapid rate. Wind plants have a much shorter planning and building schedule than conventional power technologies. Some examples of planned or in-process WEC wind projects include a 300-700 MW in Montana, 500$700 \mathrm{MW}$ in Idaho, and several hundred MW of wind farms planned in Wyoming and other northwestern and western states. In British Columbia, projects totaling over 710 MW of wind capacity are planned, while in Alberta new transmission infrastructure that can accommodate up to 2,700 MW of wind generation in Southern Alberta is under construction [28]. NaiKun Wind Energy Group in British Co- lumbia is working to advance the province's coastal wind energy potential with a project that, if built, will involve up to 110 turbines and a potential capacity of up to 1,750 MW [29].

Recent increases in WEC wind power capacity have been strongly driven by energy pricing and regulations/policies, subsidies, and other incentives. For example, production tax credits and renewable portfolio standards have boosted wind industry development [30]. As the scale of wind power increases, the wind power industry can no longer be confident that current subsidies will continue, which may slow growth of wind power generating capacity. Wind resources tend to be located in remote areas, requiring a confluence of transmission and wind resources coupled to population centers to effectively integrate and serve the markets. A possible answer that deserves study is how to cost-effectively fuel electricity growth in the region using both wind and natural gas, both low 


\section{Renewable Einergy Resources}

carbon sources. Separately, neither is ideal. But together, they offer increased reliability and generation with low price volatility and low overall carbon emissions.

\section{Solar}

The WEC has solar energy potential, especially in its southern extreme [Figure 14]. The amount of solar energy in some parts of Colorado, Utah, and Wyoming are among the highest in the U.S., with levels exceeding $6 \mathrm{kWh} / \mathrm{m}^{2}$ per day.

In 2009, the installed solar electric capacity in WEC was less than 40 MW, most of which comes from residential installations. Colorado is the only jurisdiction with total grid connected photovoltaic (PV) installations exceeding $1 \mathrm{MW}$

[Table 13]. Other efforts within the WEC are underway as well. For example, in Medicine Hat, Alberta, the first solar-powered steam generation system in Canada will use parabolic dishes to focus sunlight to produce heat for a steam turbine [31]. The U.S. Department of En- ergy (DOE) is funding a project in Utah designed to facilitate at least 10 MW (or an additional 10,000 solar PV systems) of new solar PV installations by 2015 [32].

Currently, the capital cost of photovoltaic and solar thermal power plants, relative to annual energy production, is extremely high.

New technologies in solar energy, such as concentrator photovoltaic (CPV) approaches, could reduce the cost and increase the adoption rate [33]. Similarly, decreasing costs could increase the adoption at a household scale. Additional cost reductions could come from improvements in production, manufacturing, and installation techniques.

Figure 14.

Photovoltaic solar resources in the WEC. [M7]

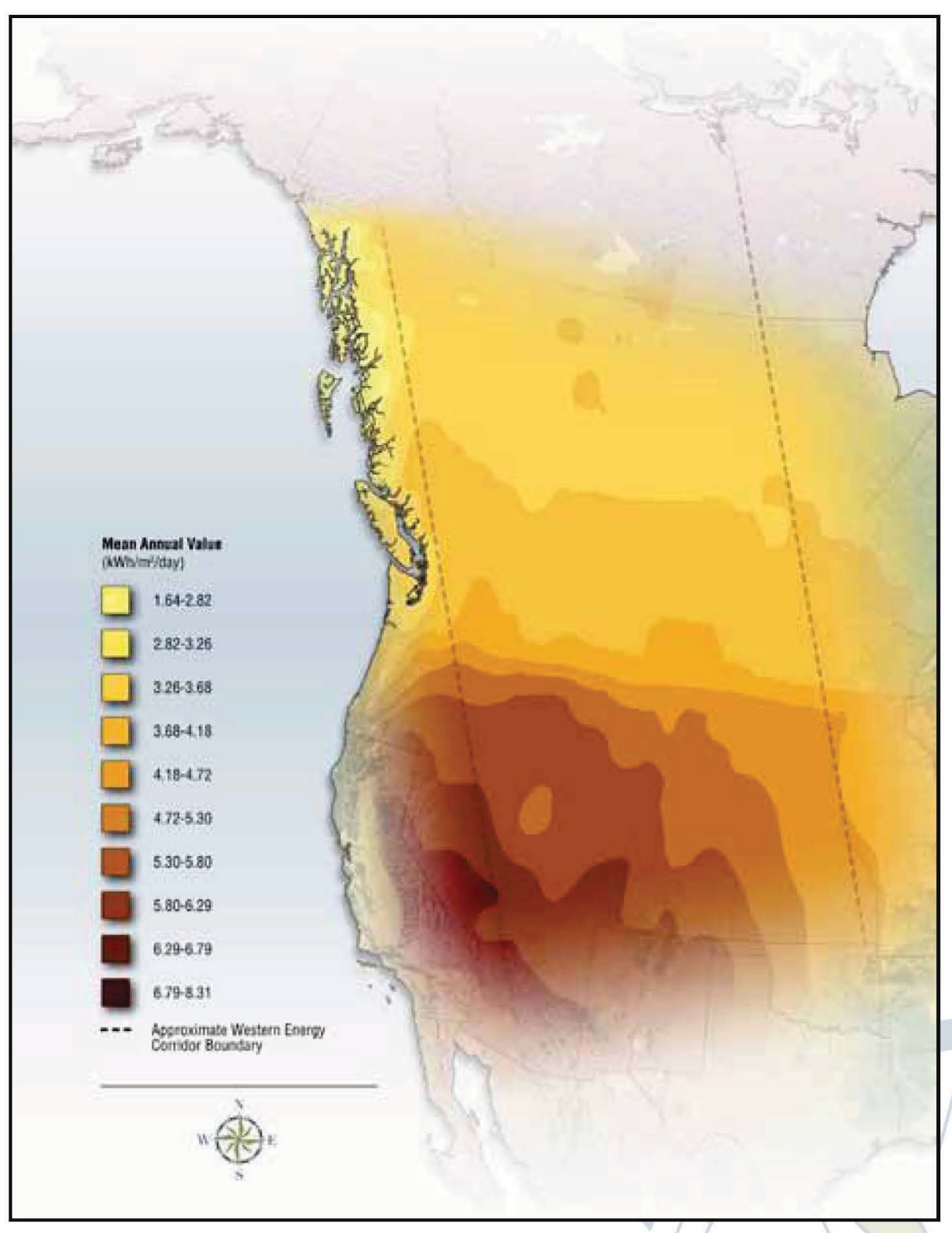




\section{Renewable Einergy Resources}

\section{Biomass}

Within the WEC, ample herbaceous and woody biomass resources exist [Figure 15] that are suitable as feedstock for production of electrical power, transportation fuels, or heat. Biomass can be used in biochemical conversion processes such as fermentation to produce ethanol, or in thermochemical conversion processes such as direct combustion, gasification, or pyrolysis. In addition, transesterification, a chemical process in which oil seeds are used to produce diesel fuel, contributes to transportation fuels. Potential bioenergy resources in the WEC include grain and agricultural residues, forest biomass and woody residues, and mill and urban wood waste, annually generating over 170 million metric tons ( $\sim 187$ short tons) of material [Table 14]. The Canadian provinces in the WEC have much more in total resources available than the U.S., largely due to geographic differences. Furthermore, not all the materials discussed would be readily available for bioenergy production, as there may be compet- ing uses. This is particularly true for grains, which are largely used for food and feed, and for straw, which is in high demand for animal bedding. Potential also exists for growing dedicated energy crops that have no food value such as poplar, miscanthus.

Grain production is a major source of WEC biomass and generates substantial agricultural residues as a by-product. Grain is included as a biomass potential, because technologies are already available for conversion of corn and wheat to ethanol. Lignocellulosic residues from food and feed grain crops can also be used to produce ethanol and other products, but there are, as yet, no full scale commercial production facilities. Saskatchewan, Alberta, South Dakota, and North Dakota are world-class grain producers, and have a relatively higher volume of agricultural residues. A shift to integrated bio-

Figure 15.

WEC biomass feedstock potential. [M8]

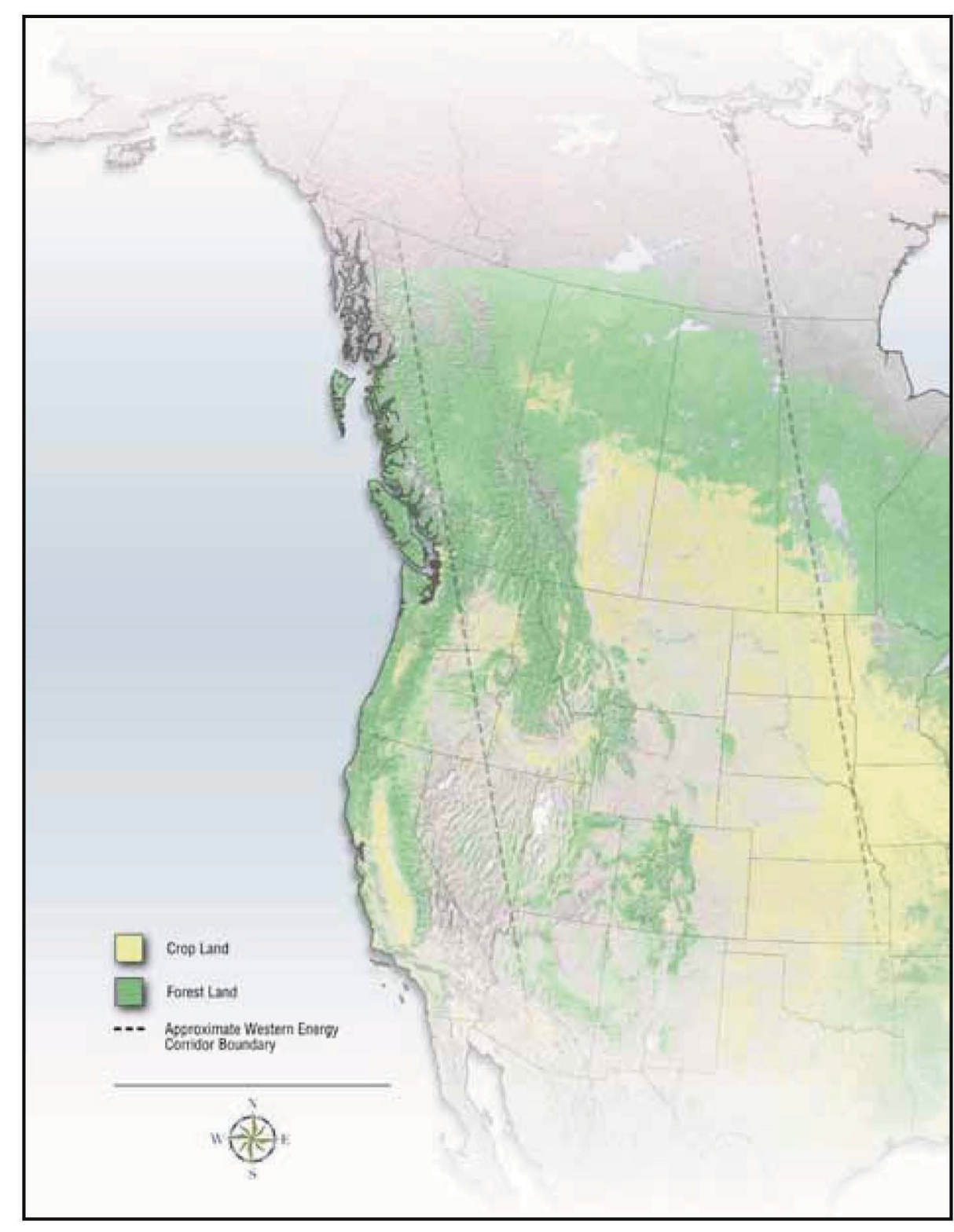


refining, rather than facilities producing a single product, may help optimize the co-production of food, energy, and other bio-based products.

The WEC also has significant forest resources with associated quantities of residue - in particular, large quantities exist in British Columbia and Alberta. In 2010, British Columbia produced one million bone dry metric tons (BDt) of wood pellets, most of which was exported to Europe for power production. A potential source of forest residue is pine beetle damaged timber. Natural Resources Canada (2011) estimates that the current rate of spread will kill $80 \%$ of mature pine trees in British Columbia by 2013 - over 1 billion $\mathrm{m}^{3}$ ( 35 billion $\left.\mathrm{ft}^{3}\right)$ of trees. The current beetle epidemic affects more than 8 million hectares (20 million acres) of forest in British Columbia $[34,35]$ and may continue to affect Alberta's northern boreal forest. The infestation has also hit Colorado, Montana, Idaho, and Wyoming.
The most effective conversion process depends on the nature of the biomass resource. For example, high-ash agricultural residues may damage thermochemical conversion process equipment; however, certain woody biomass species may have components that resist biological conversion processes used for ethanol production. Trends towards energy crops, which take advantage of marginal lands, may shift the distribution of biomass resources in WEC.

The U.S. has historically focused its biomass program on the production of biofuels in an effort to move away from foreign oil dependency. However, recognizing the large potential for biopower electricity or process heat, the U.S. Government is supporting more biopower development [36]. Canada has not had the same incentive to produce biofuels because it has a smaller population and some of the largest petroleum reserves in the world. Canada does, however, support the reduction of $\mathrm{CO}_{2}$ emissions from fossil power generation and favors the displacement of fossil fuels with biofuels. Of note, the Alberta Government as well as the Canadian government have placed a large investment in development of Triticale, a hybrid of wheat and rye, as an energy crop which can grow on marginal lands.

\section{Geothermal}

The WEC has significant geothermal potential. A 2011 report of the U.S. geothermal capacity [37] indicated that the five WEC states included in the study have at least 1,409 MW of near-commercial developments and 4,398 MW of initiated projects [Table 15]. Similar estimates have not been made for other jurisdictions, so there is no definitive estimate for the entire WEC. However, British Columbia alone has an estimated 3,000 MW of geothermal electricity potential; Alberta and Saskatchewan have less potential. The greatest potential for WEC geothermal electricity production is in its western portion, as suggested in the heat flow map shown in Figure 16. All jurisdictions in WEC have opportunities for greater utilization of low-temperature geoexchange for heating and cooling applications.

Essentially, all geothermal power plants within the WEC are located in areas having higher heat flows. These areas, combined with adequate ground water and available transmission, offer an opportunity for producing reliable, available, high-value, low-carbon electricity. But not all potential sources are available - some are difficult to access or within protected areas such as a national park. The presence of cooler water at shallow depths can mask the geothermal potential of some resources (the Cascades, for example) or complicate geothermal characterization (such as the Snake River plain).

Despite this, some geothermal potential has been realized in the WEC. As of March 2011, installed geothermal capacity in the WEC was 58 MW between Idaho, Wyoming, and Utah [Table 15] and geothermal projects are under development in Wyoming, Colo- 


\section{Renewable Einergy Resources}

rado, Utah, and Idaho. Of particular note, the estimated resource under development in Idaho alone is between 703 and $778 \mathrm{MW}$ [37], illustrating the potential across the region. Although no geothermal resources have been developed for power production in Canada, the South Meager project in British Columbia is being evaluated and could support up to $100 \mathrm{MW}$ [38]. Increasing interest in renewable energy for non-electricity applications has led evaluation of several geothermal projects for development in British Columbia and Alberta.

Recent efforts have explored other innovative uses of geothermal resources such as using the hot water co-produced with oil and gas to generate electrical power. Examples include a $250-\mathrm{kW}$ facility recently made operational in Wyoming [39], and a $1 \mathrm{MW}$ project being proposed in Alberta [40]. Another opportunity is the potential for zones beneath the $\mathrm{Ca}$ nadian oil sands to pre-heat water used to make steam for in-situ oil sands mining operations [41]. The Massachusetts Institute of Technology's 2006 estimate indicated that potential power from the co-produced fluids could exceed $450 \mathrm{MW}$ within the WEC [42].

Geothermal energy may be an economically viable resource, but it requires sufficient temperature, water, and permeability at economically retrievable depths. Locating resources with these characteristics is the greatest challenge to developing geothermal energy. Enhanced Geothermal Systems (EGS) technologies - which aim to enable the use of geothermal energy when heat is present but water and/or permeability are not - could significantly expand geothermal power in the WEC [41]. Several technical and economic issues must be resolved before this potential can be realized. The U.S. DOE is developing goals to provide significant amounts of EGS power by 2030 and 2040; however,

Figure 16. WEC geothermal potential. [M9]

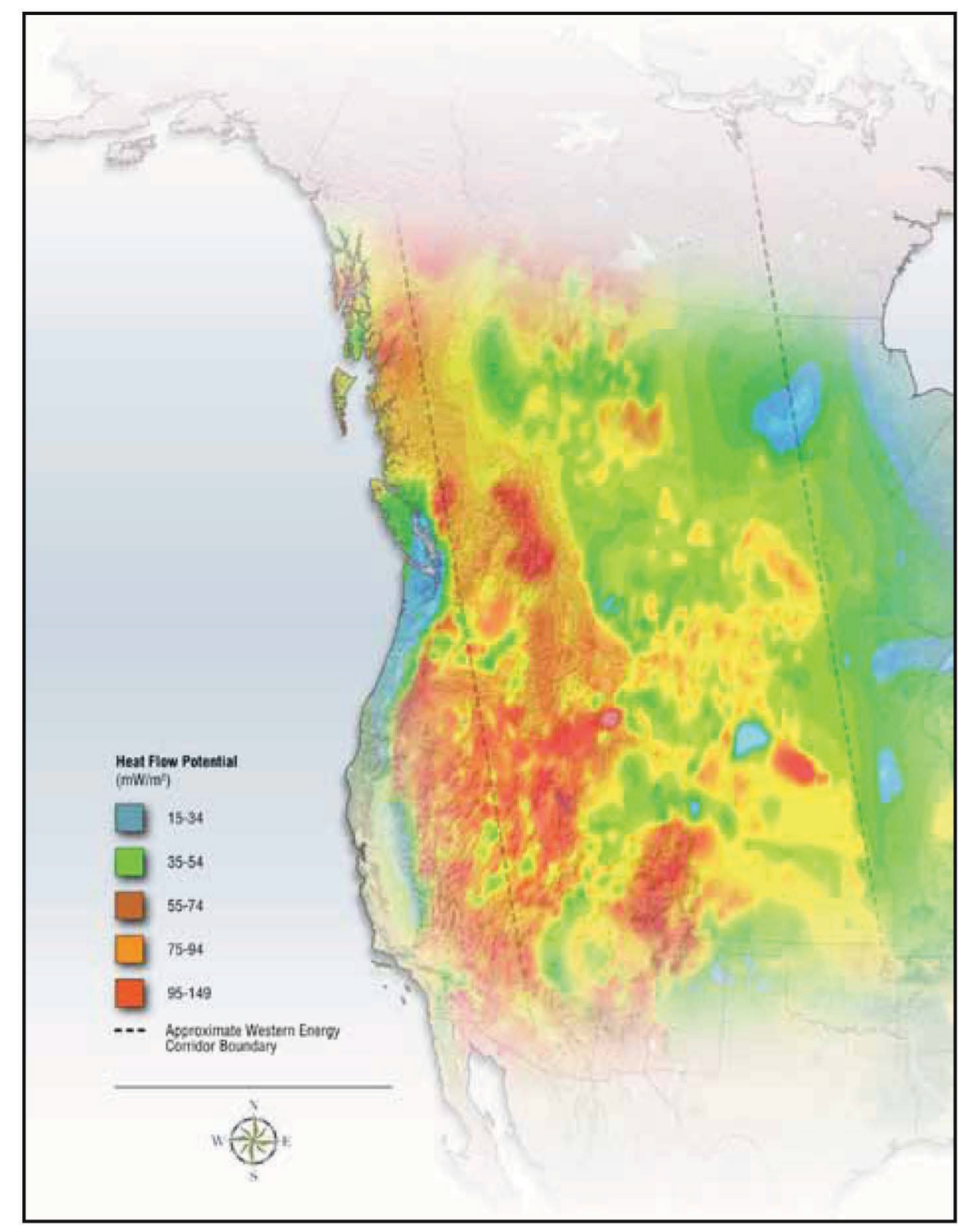




\section{Renewable Energy Resources}

details (including timeline) for the goals have not been finalized.

\section{Tidal/0cean Energy}

British Columbia is the only area in the WEC that has ocean wave and tidal energy resource potential. For the British Columbia coast, the total deep water annual wave power potential is approximately 37,000 MW, and total tidal current power potential is approximately 4,000 MW [43]. The best sites for capturing strong tidal currents are in the Strait of Georgia and Johnstone Strait as shown in Figure 17 , which offer the major benefit of proximity to the point of use. High-potential sites for ocean current may be farther away from land [44]. The number and capacity of potential tidal and ocean current sites could increase as improved technologies are developed.

High cost and limited site availability have traditionally plagued tidal and other ocean-energy projects. Tidal energy requires a confined location with sufficiently high tidal ranges or flow velocities.
The cost of tidal and ocean energy is highly influenced by geography, distance to grid, and water conditions (i.e., speed and volume of the current) [45]. Although wave energy resembles wind generation in its intermittent nature, it is easier to forecast and has a uniform availability. Specifically, ocean waves propagate at a constant speed with little attenuation, so they can be detected several hours before reaching a generator. Tidal and ocean-current energy systems must endure extreme weather conditions and corrosion, and maintenance is expected to be expensive.

Figure 17.

Wave power and tidal current energy potential. [M10]

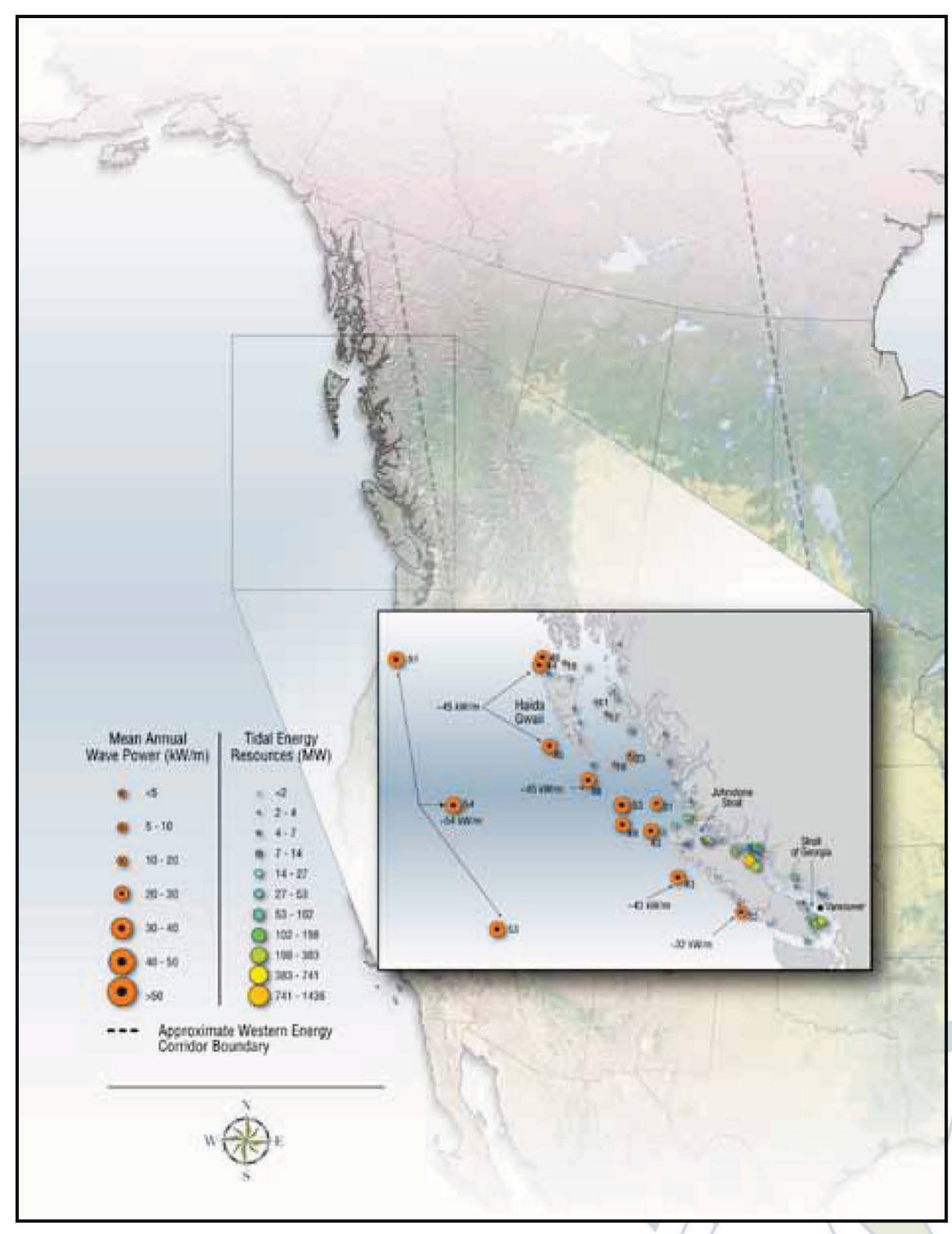




\section{Uranium Resources}

The WEC contains significant quantities of uranium [Figure 18], which is used to generate electricity in nuclear power plants. Canada's sole uranium-producing area is in Saskatchewan and is second in world production only to Kazakhstan. In 2010, Saskatchewan produced 10,784 short tons (9,783 metric tons) of uranium just over $18 \%$ of world production. Saskatchewan's McArthur River Mine, which is the largest producing uranium mine in the world, produced 8,437 short tons (7,654 metric tons) of uranium, or approximately $14 \%$ of the world's uranium output in 2010. Known recoverable uranium resources in Saskatchewan are estimated at 466,000 short tons (423,000 metric tons) of uranium based on a 2007 estimate [46], $8 \%$ of the world's known recoverable resources [47].
In 2010, the U.S., ranked 8th in world uranium production, generating 1,830 short tons $(1,660$ metric tons) of uranium [46], much of which came from mines in Colorado, Utah, New Mexico and Wyoming, with the latter two states dominating[48]. According to a 2009 estimate, the U.S. has known recoverable resources of 228,000 short tons (207,000 metric tons) of uranium [47]. In 2008, Wyoming led the nation in total uranium reserves; together, Wyoming and New Mexico contain about twothirds of the country's estimated reserves [49]. An important note in relation to British Columbia is that in April 2008 a news release indicated that the Province will not support the exploration and development of uranium.

Figure 18.

Distribution of uranium resources in the WEC. [M11]

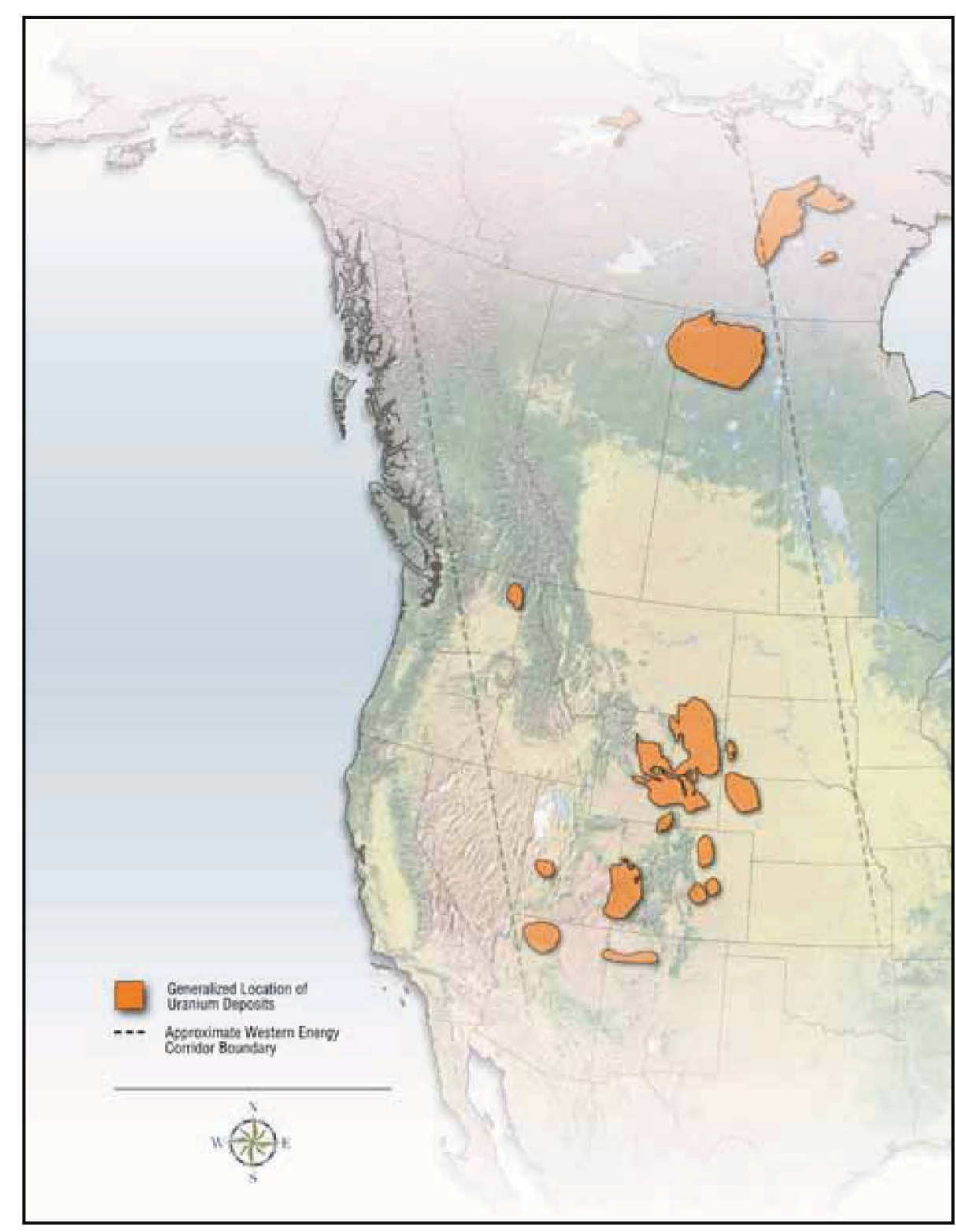




\section{Uranium Resources}

Half of the nuclear fuel currently used in the U.S. is derived from dismantled Russian nuclear warheads. This program will be halted in 2013, which may result in increased demand for uranium resources within the WEC.
The WEC also contains significant quantities of thorium, especially in Idaho. Unlike uranium, thorium has not been used extensively for nuclear energy production, although it has been successfully used to experimentally generate energy in many countries including the U.S., Canada, Europe, Japan, Russia, and India. Thorium has not been a major competitor with uranium for use as a nuclear fuel because the world supply of uranium is sufficiently inexpensive and abundant to meet current needs [50]. Some countries (namely, India) may, however, favor thorium over uranium as a fuel source, depending upon local availability and policy [47].

\section{The McArthur River Mine, located in Saskatchewan, is the largest producing mine in the} world with over 7,600 metric tons of uranium produced in 2009, approximately $14 \%$ of

\section{the world's uranium production.}
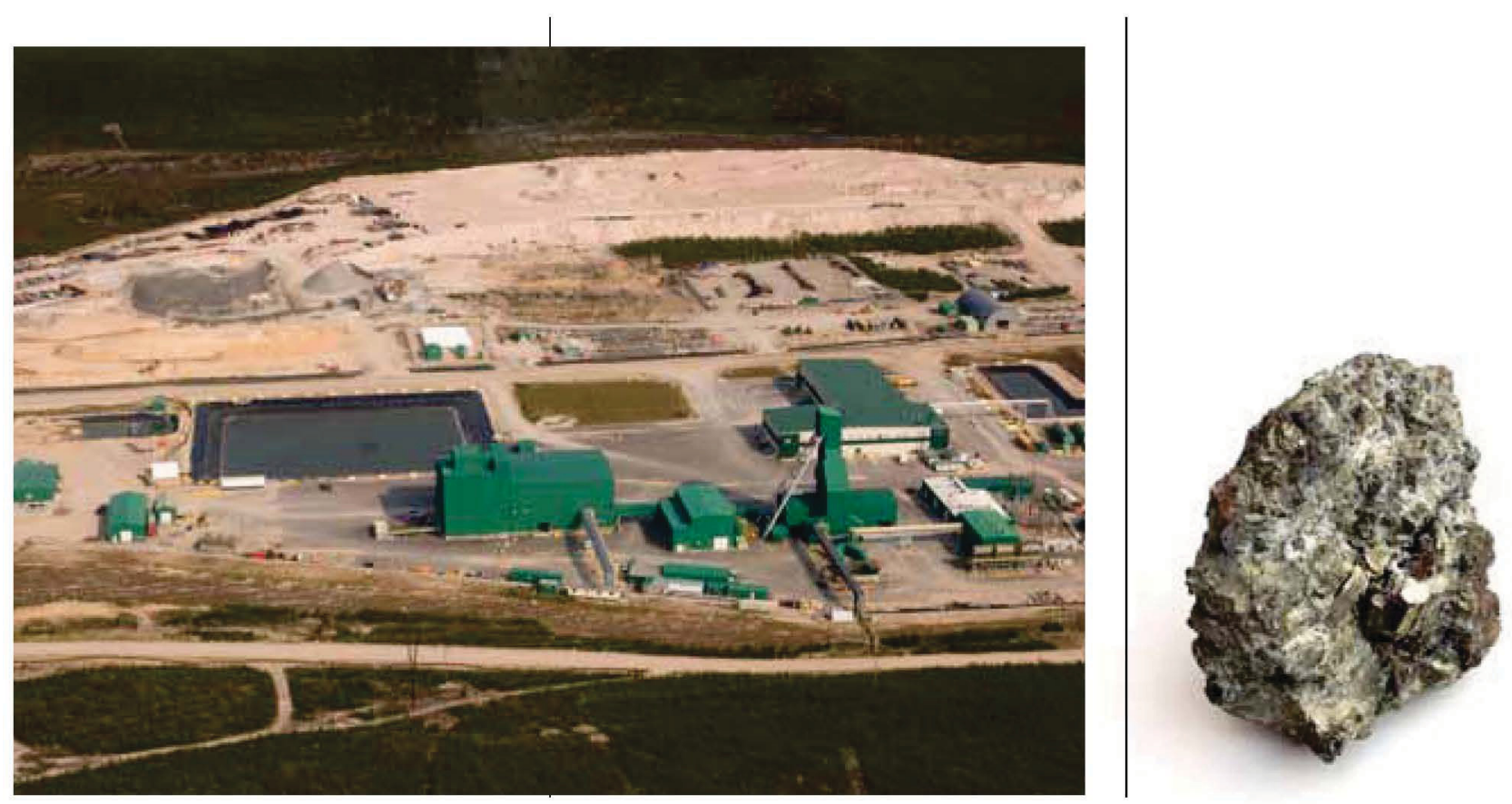


\section{Electricity Power Generation}

n 2009, the WEC's electric power generation capacity _was estimated at over 75,000 MW; Colorado led with 13,045 MW, followed by Alberta at 12,996 MW. Figure 19 and Table 16 show the generating capacity by state/province and source. The WEC generation capacity is dominated by coal-fired infrastructure followed by hydropower and natural gas, as shown in Figure 20 . Over $60 \%$ of WEC generation capacity is supplied by fossil energy. Although renewable energy production capacity is increasing, outside of hydropower, its sources make up less than $10 \%$ of the total capacity and are led by wind power investments [Table 21]. No commercial nuclear power plants (NPPs) exist within the WEC, but there are emerging interests in their inclusion. Total electrical energy generation within the WEC in 2009 was over 370 million MWh. Of this, more than $70 \%$ came from fossil energy plants (primarily from coal and natural gas), 24\% from

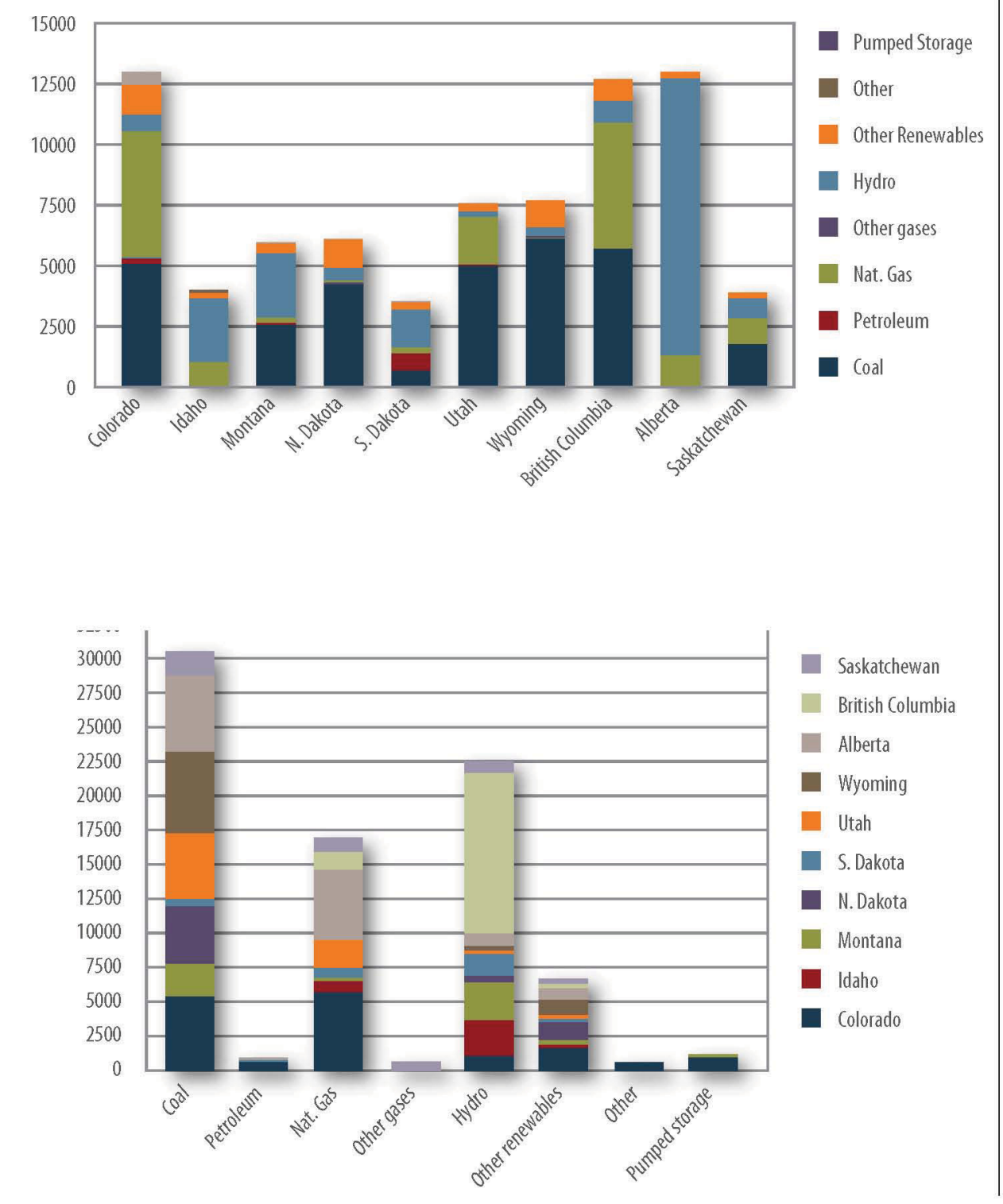

Figure 19. WEC electric power installed capacity by statel province.
Figure 20. WEC electric power installed capacity by source. 
hydropower, and approximately $4 \%$ from other renewable [Table 17]. The low capacity factor of wind power plants results in a far smaller contribution to annual electric generation than to generating capacity.

\section{Coal-Fired Electric Power Generation}

In 2009, coal-fired plants were estimated to make up approximately $40 \%$ of the electricity generation capacity within the region - approximately 30,500 MW. Alberta has the largest capacity $(5,971 \mathrm{MW})$ followed by Wyoming and Colorado [Table 16]. Since 1999, the WEC's overall capacity from coal-fired plants has changed very little with the exception of Montana, which has lost approximately $20 \%$ of its coal-fired electrical generation capacity over the last 10 years. British Columbia generates no electricity from coal. It should be noted that 2010 actually represents the largest build of coal-fired plants since 1985 within the U.S., which included the
Comanche (850 MW) and Wygen II (110 MW) plants, located in Colorado and Wyoming, respectively [51].

Coal is estimated to continue playing a foundational role by providing base load power in the long term within the WEC. New coal plants are continuing to be introduced, especially in Wyoming, North Dakota, and Alberta. An example of a new plant construction is the combined heat and coal-fired power plant (Spiritwood Station) in North Dakota. It uses dried and refined lignite, will produce nearly 100 MW during peak demands, and will provide steam to a nearby malting plant [52]. However,

Environmental Protection Agency (EPA) and state regulations on air emissions, coal ash, and water are expected to drive retirement of

\section{Given the abundant natural gas, coall, and hydropower resources within the WEC, the region is}

\section{able to supply some of the most reliable and lowest priced electricity in North America.}

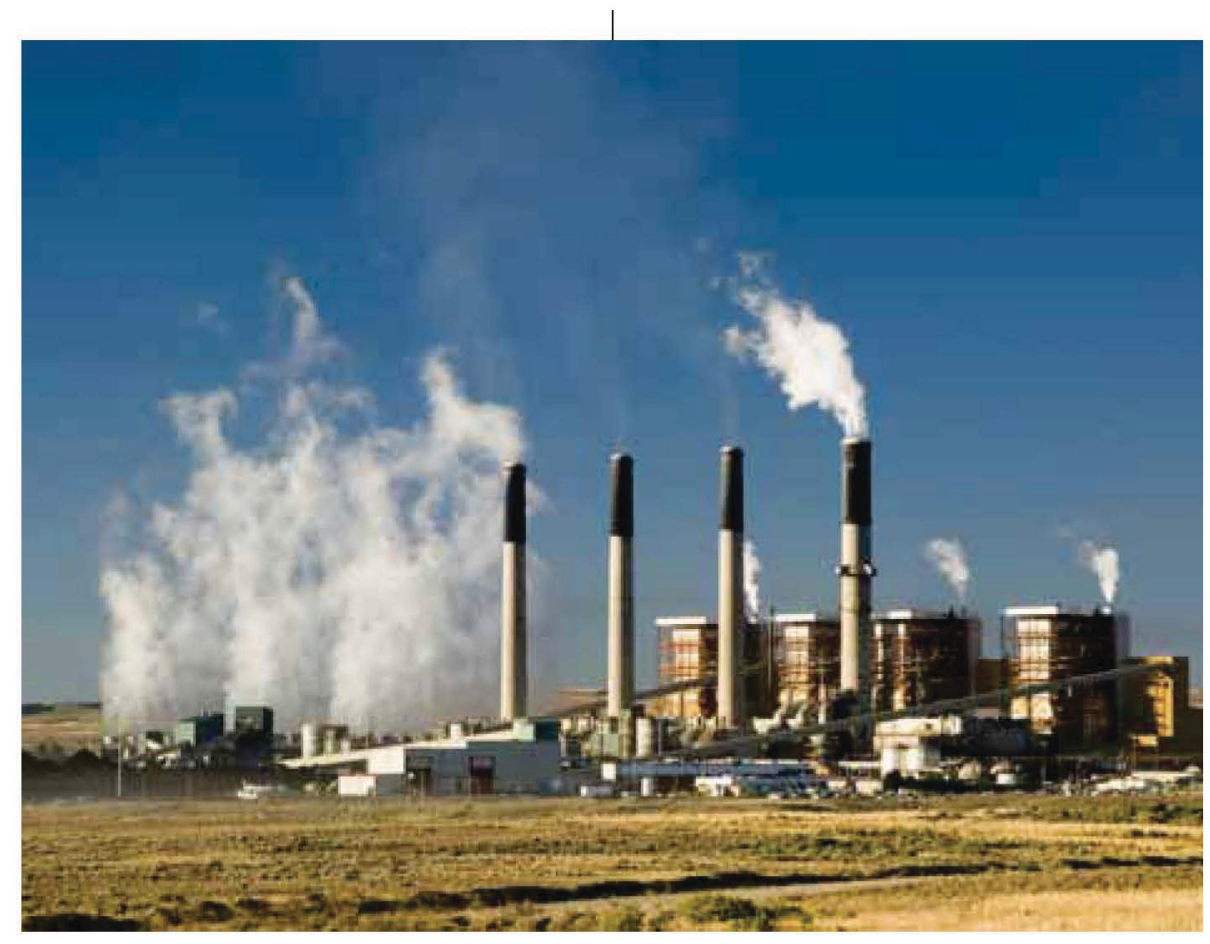

certain existing coal-fired generation plants. For example, Colorado utilities are being directed to retire or retrofit coal capacity and replace it with natural gas or renewable energy resources to comply with new state Clean Air-Clean Jobs Act [53]. Another trend is the pursuit of higher efficiency in power production while reducing environmental impact. Enabling clean coal technologies include $\mathrm{CO}_{2}$ capture and sequestration, underground gasification, integrated gasification combined cycle (IGCC), and oxyfuel combustion (coal gasification). 


\section{Natural Gas}

In 2009, gas-turbine-based plants within the WEC provided just over $22 \%$ of the generation capacity, with Colorado and Alberta leading at 5,357 MW and 5,201 MW, respectively [Table 16]. The last ten years has seen significant investment in gas-fired generation, with notable examples in Colorado, which grew in capacity from 691 MW in 1999 to almost 8 times that amount in 2009 $[54,55]$. During this same period, Alberta doubled its own capacity in natural-gasfired electricity generation.

The attractiveness of natural gas is growing due to low natural gas prices and the fact that it is the cleanestburning fossil fuel and has relatively low capital construction costs. Concerns, however, remain relative to the long-term position of gas given the historic volatility of gas prices.

\section{Renewable Energy}

Hydropower makes up approximately $28 \%$ of WEC electric generating capacity, with British Columbia by far the highest at $11,000 \mathrm{MW}$, just over $50 \%$ of the entire WEC hydropower capacity [Table 16]. Hydropower contributed approximately $24 \%$ of total WEC electric energy generation in 2009, and more than
63\% came from British Columbia [Figure 21]. In 2009, the WEC produced almost 90 million MWh from hydroelectric energy [Table 17].

Electric power capacity from other renewable sources is dominated by wind, which provides approximately $90 \%$ of the WEC's nonhydro renewable capacity [Table 21; Figure 22]. Wind power is also the fastest growing source of new, renewable electric power generation. Within the WEC, wind power generation is led by Colorado, followed by North Dakota and Alberta; together they represent over $77 \%$ of the WEC's wind generation. Total WEC generation from wind in 2009 was just under 10 million MWh [12]. The growth in U.S. wind farm generation is

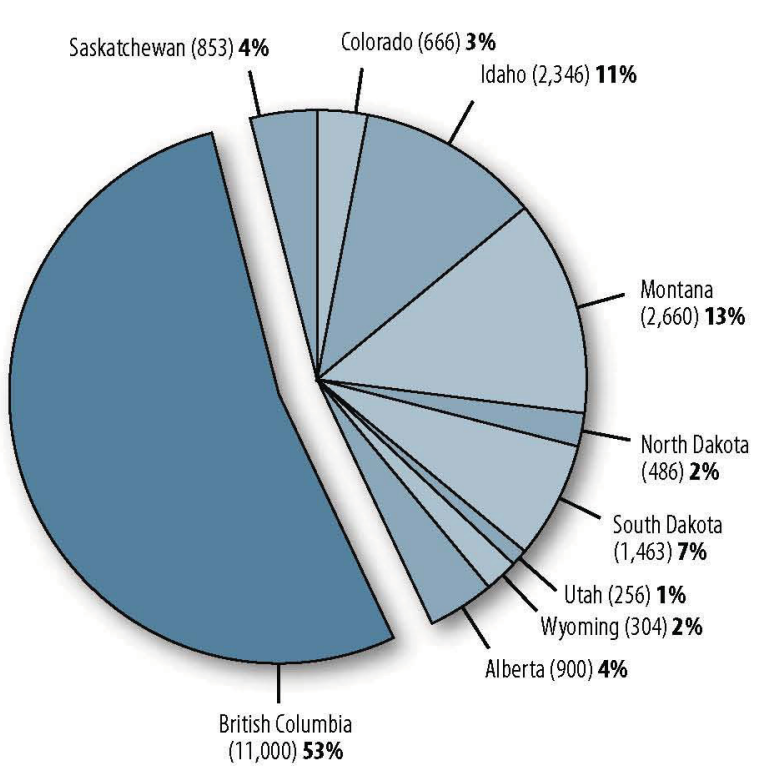

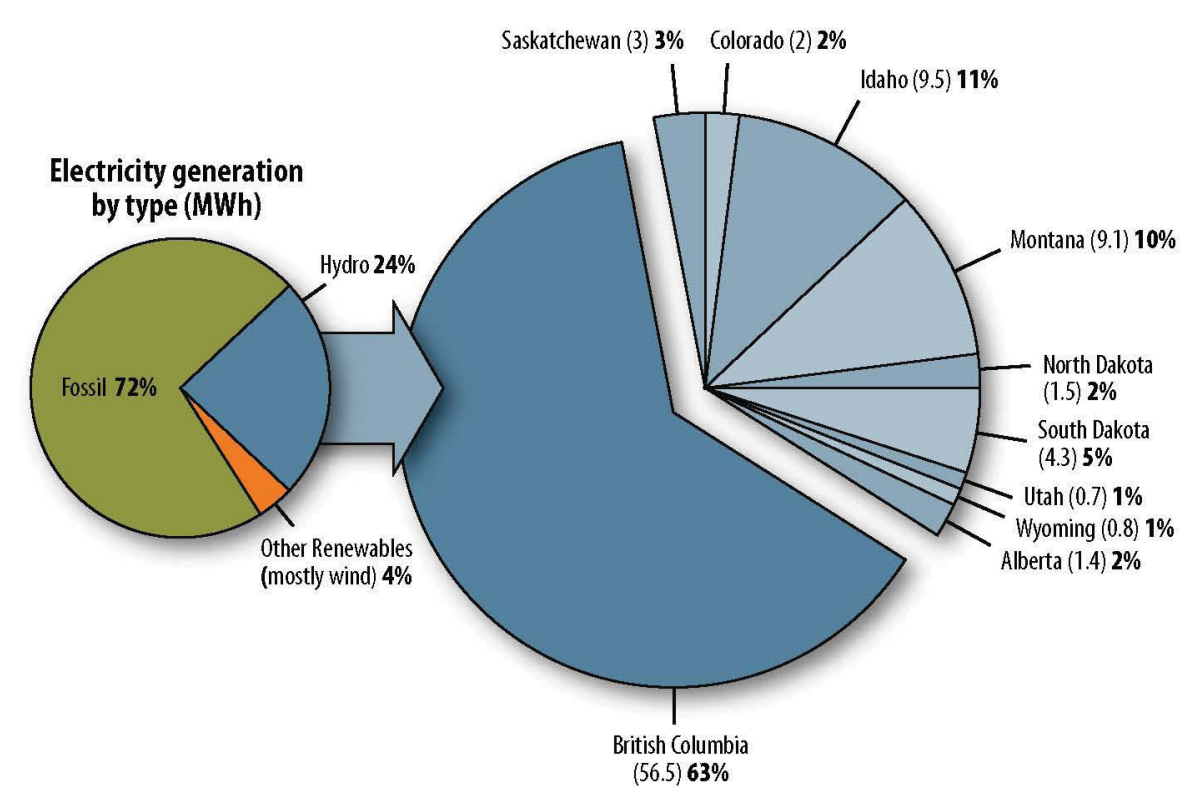

Figure 21.

Hydropower generating capacity (MW)
Figure 22.

Hydropower generation (million $M W h$ ). 


\section{Eilectricity Power Generation}

\section{In 2009, 90 million MWh of electricity was generated from hydropower in the WEC which represents approximately \\ $24 \%$ of the WEC's total electricity generation that year.}

driven primarily by state renewable portfolio standard (RPS) requirements and federal tax credits. The remainder of renewable energy sources includes biomass, geothermal, and solar [Table 20].

\section{Nuclear Energy}

The WEC has no operating commercial nuclear reactors, but there has been recent interest in building them within the region. In 2008, Bruce Power applied for a license to prepare a site for the future construction and operation of a new reactor complex (4,000 MW) on the Peace River in northern Alberta. The company has since withdrawn the application [56]. Alternate Energy Holdings, Inc. is pursuing preliminary local approvals to develop the "Idaho Energy Complex" in Payette County, Idaho, in advance of an application to the U.S. Nuclear Regulatory
Commission (USNRC). In 2012, the USNRC is anticipating license applications for two new nuclear power plants near Green River, Utah. British Columbia has a moratorium in place that prohibits nuclear power [57].

Relative to other nuclear energy infrastructure, AREVA plans to develop a uranium-enrichment plant 20 miles west of Idaho Falls, Idaho. The license approval process is almost complete, and construction is expected to start soon after. The facility's capacity will fuel 25 reactors producing 1,000 MW each, with the possibility of doubling that capacity if market conditions are favorable [58]. Also near Idaho Falls, INL operates a 250-MW (thermal) Advanced Test Reactor (ATR) for materials and nuclear fuel testing. In eastern Washington, a commercial nuclear power plant provides elec-

tricity to some areas of the WEC but is not included in this report.

Saskatchewan is interested in increasing the value of its uraniumbased products and has conducted a feasibility study addressing the nuclear energy cycle beyond its current activities in mining and

milling. The province is moving to drive nuclear-related research and development (R\&D) and is exploring other opportunities associated with power generation, repositories, and enrichment [59]. 


\section{Liquid Fuels Production}

$\mathrm{n}$ addition to conventional petroleum refineries located _within the WEC, several large existing and future investments are being made in infrastructure associated with bitumen and heavy oil upgrading. Interests are also emerging in non-traditional fuels production infrastructure associated with liquefied natural gas (LNG) and coal-to-liquids (CTL) production within the region. In parallel, a liquid biofuels industry is emerging around vast quantities of biomass, including forest residue, corn, wheat, and oil seed.

\section{Petroleum Refineries and Upgraders}

Twenty-seven crude oil refineries are located throughout the WEC with a total of 1.3 million barrels per day operable capacity [Figure 23]. Alberta's three refineries comprising over $30 \%$ of the WEC's capacity. For perspective, in 2010 , the U.S. had 16 million barrels per day of operable capacity [Table $18]$.

Alberta and Saskatchewan contain six upgraders with a 2009 collective operable capacity of 1.2 million barrels per day. Their primary focus is upgrading bitumen from oil sands and heavy oil to produce synthetic crude oil. Three new upgrader projects and three expansions are either approved or under application in Alberta. They could collectively bring additional upgrading capacity of nearly 1.0 million barrels per day of bitumen [60].

\section{Liquid Natural Gas Facilities}

An LNG plant and shipping terminal is being planned for Kitimat, British Columbia, with a capacity of 5 million metric tons (5.5 short tons) per annum and the potential to double processing capacity in a

Figure 23. Fuel processing plants. [M12]

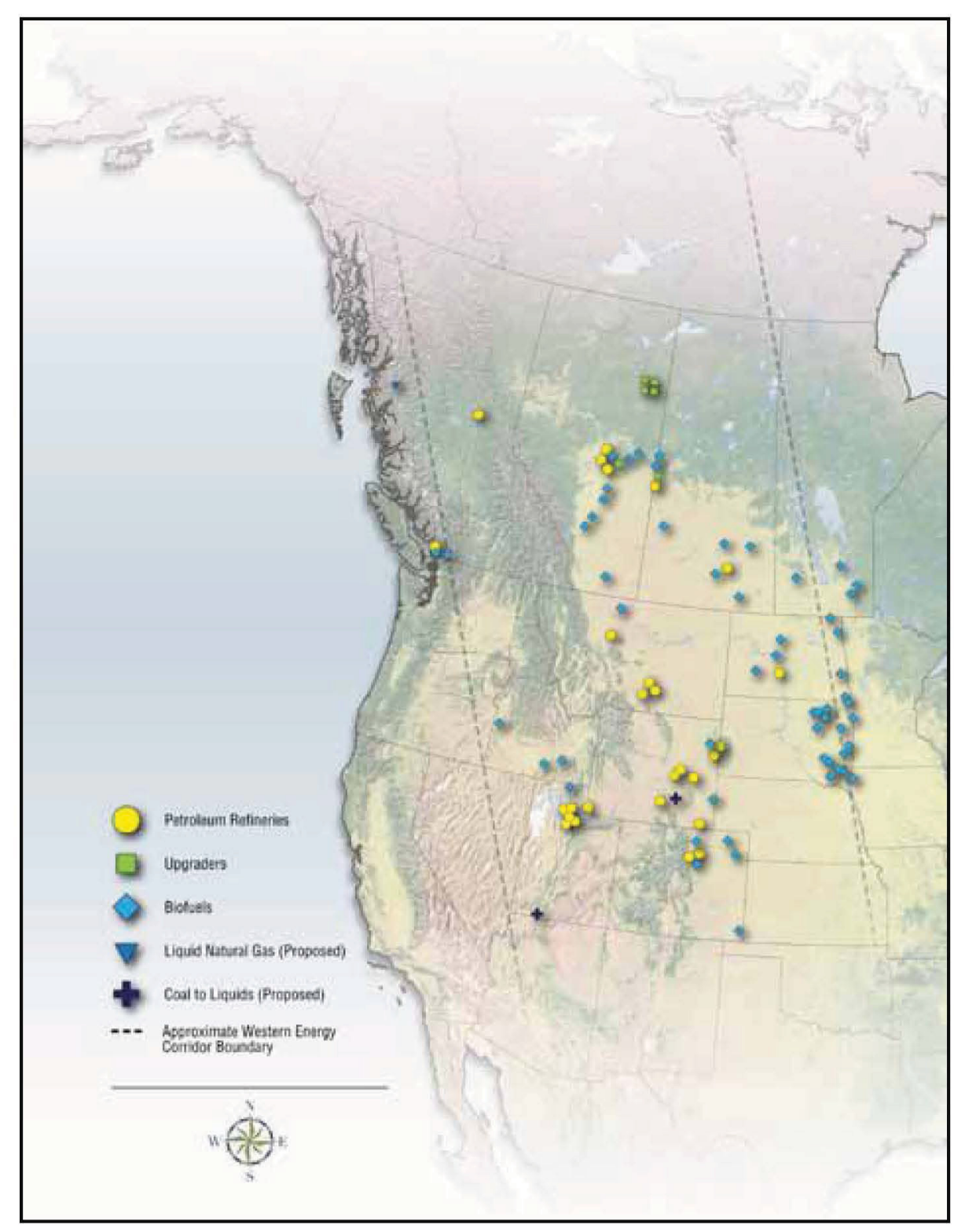




\section{Liquid Fuels Production}

Phase 2 expansion; the target date is 2015 for the first LNG shipment. An application for a second plant and terminal at Kitimat has been submitted to the National Energy Board for a Canadian Federal Export License [61]. The facilities would tap British Columbia and Alberta natural gas resources and target Asian markets to complement the existing U.S. market. At least two additional LNG projects are being studied with one project exploring construction of an export terminal in Prince Rupert [16].

\section{Coal-to-Liquids}

An emerging trend within the WEC over the past few years is assessing the feasibility of coalto-liquids (CTL) facilities, which could help develop the vast coal resources in Alberta, Montana, and Wyoming. One CTL facility development project has emerged in Medicine Bow, Wyoming. The project, which is expected to start in 2014, will use Carbon Basin coal to produce refined hydrocarbon liquid products with an initial commercial operation of up to
22,000 barrels per day [62]. There is also a proposed pilot plant in Kanab, Utah, that would use a hydrogasification process to convert feedstocks such as coal and biomass into synthetic gas suitable for processing to liquid fuel or to substitute natural gas.

\section{Biofuels}

There are currently 39 operating ethanol plants and 13 operating biodiesel plants within the WEC. These facilities have an annual operating capacity of approximately 2,000 million gallons per year $(7,600 \mathrm{million} \mathrm{bbl} / \mathrm{yr})$. South Dakota has the greatest capacity of the WEC, at approximately 1,000 million gallons per year $(3,800$ million $\mathrm{bbl} / \mathrm{yr}$ ), followed by North Dakota and Saskatchewan. All ethanol plants in the WEC use grain such as corn and wheat as a feedstock, with the exception of a 1.5 million gallon per year $(100 \mathrm{bbl} / \mathrm{d})$ pilot plant in Upton, Wyoming, which uses lignocellulosic biomass (wood waste) as a feedstock.
In the U.S., five of the seven states in the WEC have some biodiesel capacity; the highest single producer is in Casselton, North Dakota, producing 153 million gallons per year (581 million bbl/yr) [Table 19]. Although over 380 million gallons ( 9 million bbl/yr) of annual biofuels capacity is under construction in the U.S., none of it is in the WEC [63]. One ethanol plant that will use municipal waste as feedstock and has a planned annual capacity of 36 million gallons ( 0.86 million $\mathrm{bbl} / \mathrm{yr}$ ) is under construction in Edmonton, Alberta.

The WEC has a total of 68 biodiesel fueling stations with all provinces and states represented $[64,65]$. Colorado stands out with 23 biodiesel stations, followed by Wyoming with 15 as of 2009 . There are some incentives for biofuels infrastructure development in the WEC. For example, qualified biofuel fueling infrastructure in Idaho is eligible for up to $6 \%$ tax credit. Biofuels plants in North Dakota receive up to $\$ 1.6$ million/year and $\$ 10$ million over the life of the plant. [64] 


\section{WEC Energy Delivery}

$\mathrm{T}$

The processing, use, and export of WEC energy resources depend heavily on a strong underlying energy infrastructure. This section concerns bulk movements of energy resources or products, focusing on electricity transmission, oil and gas pipeline, and rail. $\mathrm{CO}_{2}$ pipeline has been included, as $\mathrm{CO}_{2}$ delivery is becoming important throughout the region for enhancing oil recovery and sequestration, and it will increasingly become integrated with other energy infrastructure.

\section{Electricity Transmission}

The WEC spans two of four major transmission reliability organizations in North America and lies within the balancing authorities of the Western Electricity Coordinating Council (WECC) and the Midwest Reliability Organization (MRO), both part of North American Electric Reliability Corporation [Figure 24]. From both market and control perspectives, these interconnections are isolated except

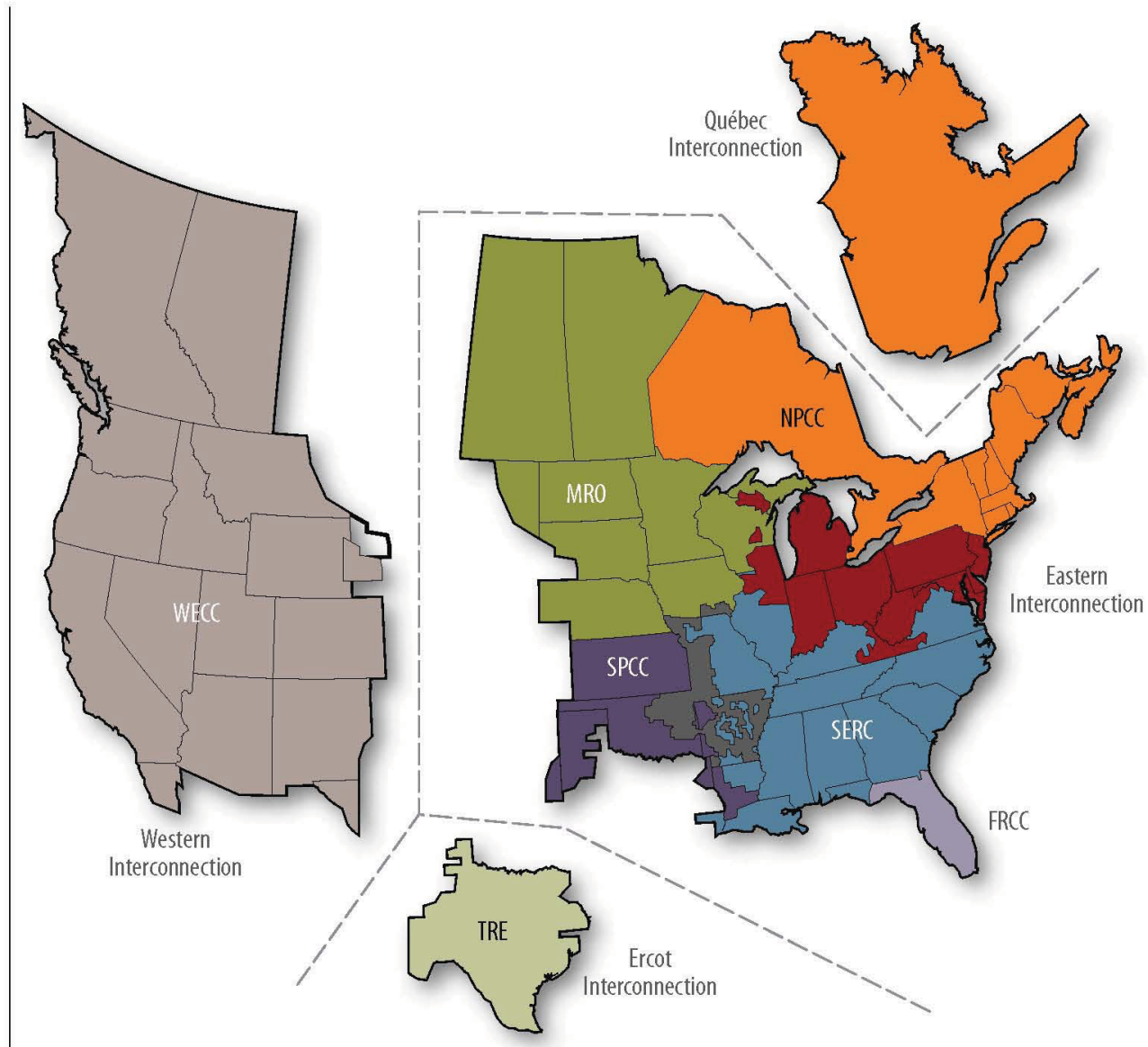

Figure 24.

Transmission interconnection grids. for a few small connection points east of the Rocky Mountains.

These points have limited power transfer capabilities or require that power be converted from $\mathrm{AC}$ to $\mathrm{DC}$ to $\mathrm{AC}$.

In short, the WEC has access to two major electric-power energy markets. They consist of a sophisticated network, involving interconnected power plants and power lines that operate at many different voltages. Figure 25 shows existing major transmission lines within the WEC.

Investment in WEC transmission infrastructure began to increase several years ago in response to various needs, including reliability and generator interconnection. The proposed transmission buildout aims partly to better capture and integrate renewable energy resources, such as wind, to meet state or provincial renewable energy requirements. Increased transmission investment in the U.S. is also due, in part, to several landmark developments in U.S. 


\section{WEC Energy Delivery}

federal and state policies affecting transmission infrastructure (e.g., the Energy Policy Act 2005), state renewable power standards (RPS), federal transmission pricing policy (e.g., Federal Energy Regulatory Commission), and federal initiatives promoting transmission Smart Grid development under the American Recovery and Reinvestment Act (ARRA).

Although the environmental permitting process for transmission line construction was slow from 2001 to 2009 , utilities that are members of the Edison Electric Institute (EEI) invested over $\$ 55$ billion USD in transmission infrastructure improvements to meet these various needs. Another $\$ 61$ billion USD in future transmission system investments is expected from 2010 through 2021 [67]. In Western Canada, the increased demand on natural resources, particularly unconventional crude oil and hydropower potential, will burden existing infrastructure and eventually require added generation and transmission. Of par- ticular relevance is the Regional Transmission Expansion Project. It is funded by the U.S. DOE, being executed by the Western Governors Association and Western Electricity Coordinating Council. The project is designed to analyze transmission requirements under a broad range of alternative energy futures and to develop long-term, interconnection-wide transmission expansion plans [68].

\section{Natural Gas Pipelines}

The North American natural gas market relies heavily on natural gas delivery from the WEC. It is underlain by a substantial natural gas pipeline infrastructure for export to various markets, accompanied by infrastructure components such as storage facilities and compression stations. In addition, there are longer-term plans to convey natural gas from the Alaska North Slope and the Mackenzie Delta

Figure 25.

Transmission lines within the WEC. [M13]

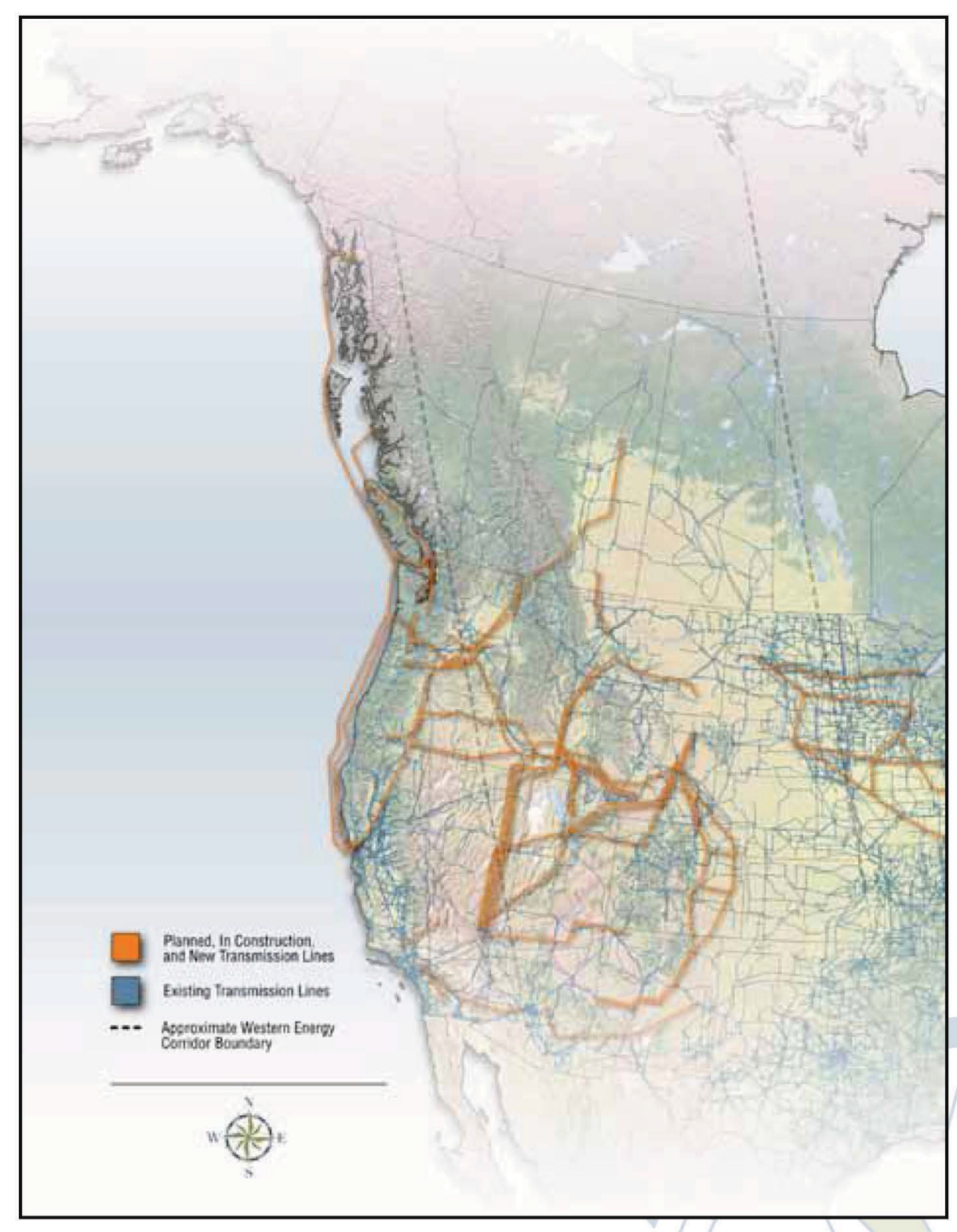




\section{WEC Energy Delivery}

area to markets in North America via the proposed Alaska and McKenzie pipelines, which would pass through the WEC and could add another $15 \%$ load to the existing pipeline network. Figure 26 shows both existing and proposed gas pipeline within the WEC.

Some WEC-produced natural gas is consumed within the region, but most is exported to other parts of North America (Canada is the number one natural gas supplier to the U.S.). Interregional flow patterns for 2008 show large movements of natural gas out of the WEC to major consuming regions in the U.S. Midwest and East

Coast, and to a lesser extent, to the West Coast and Florida. By 2030 , interregional flows are projected to increase to meet demand predominantly by accessing growing unconventional production in the midcontinent and Northern Rockies, natural gas from the Arctic projects such as along the Alaska North Slope and McKenzie Delta [69], and supplying LNG exports that would target Asian markets.
Significant investment in new pipeline and associated infrastructure will be required to support this growth.

Recently, natural gas shipments from the Canadian portion of the WEC to the East Coast have been declining, due to (a) growing shale gas production in the U.S., (b) increased use of natural gas for the extraction and processing of crude bitumen within the Alberta oil sands, and (c) increased competition from newly constructed natural gas pipelines in the U.S [70]. As a result of this decreased demand and lower market prices for Canadian gas [Figure 27], producers are exploring other potential markets including Asia. The price of LNG is much higher than North American gas prices and is especially so in Asia [71].

Figure 26.

Natural gas pipelines within the WEC. [M14]

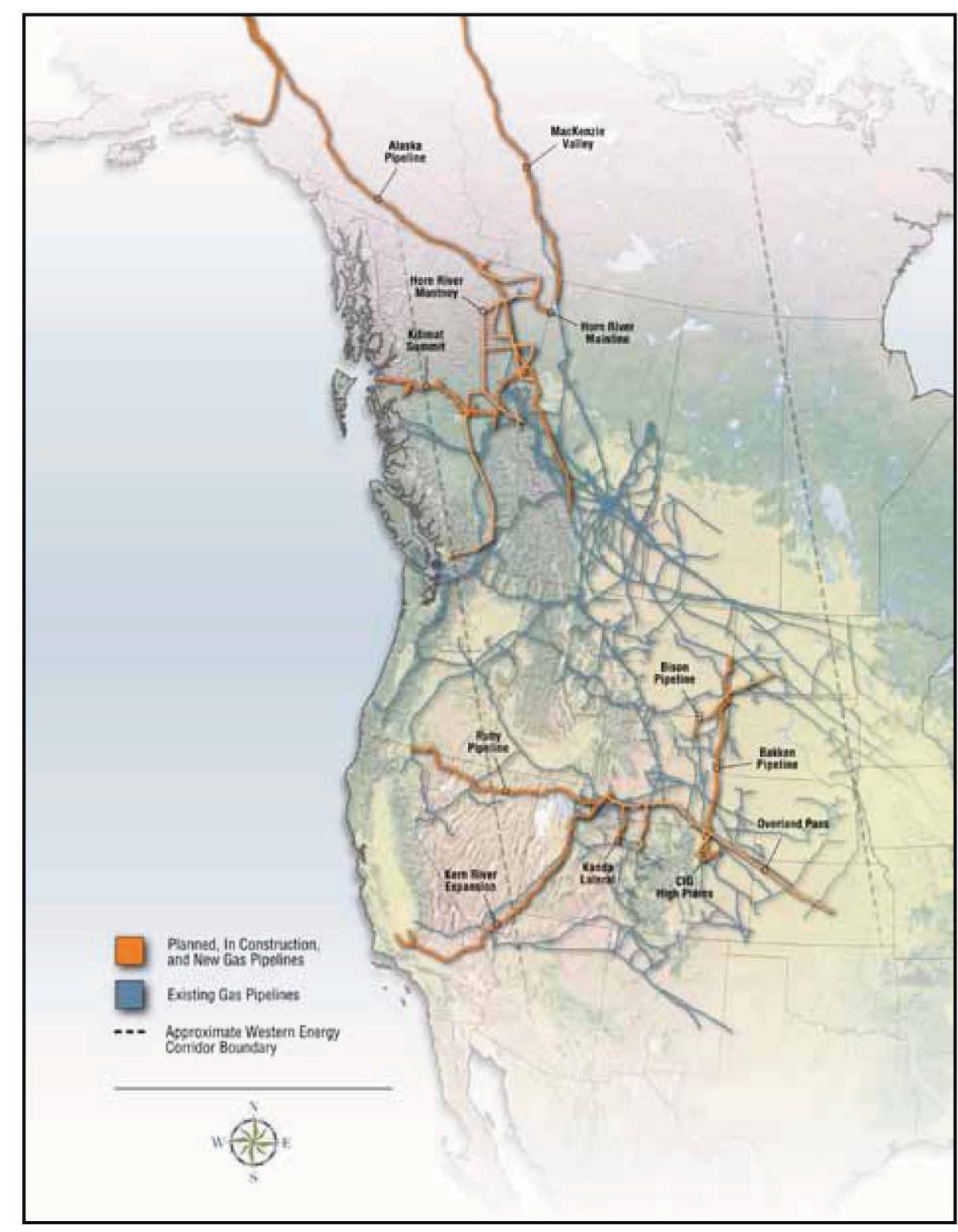




\section{WEC Energy Delivery}

When oil is produced from the Bakken formation, there is also significant natural gas liquids (and gas) produced. Much of that natural gas is flared, resulting in substantial lost revenue. Because infrastructure is needed to gather natural gas, a pipeline (ONEOK Bakken NGL Pipeline) has been

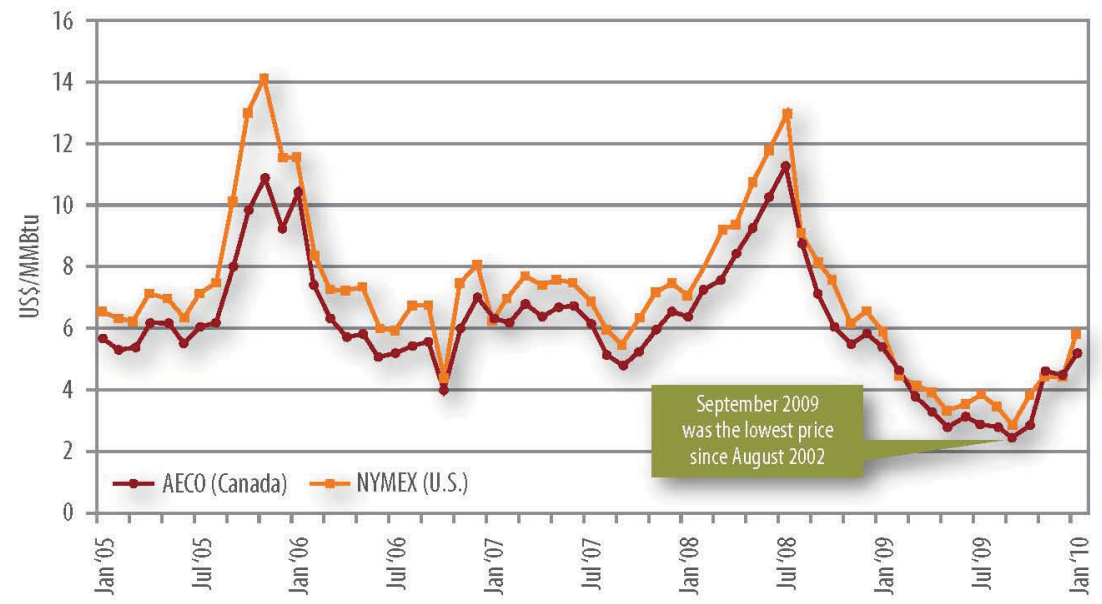

Figure 17.

Canadian and U.S. natural gas prices. [16] proposed to extend south from the Bakken Shale to connect with the Overland Pass Pipeline [72].

\section{Oil Pipelines}

The WEC contains established and growing pipeline infrastructure [Figure 28] that transports crude oil or refined product from oil-producing areas of the WEC to refineries in the WEC and the rest of North America. The U.S. is the primary destination for these resources, as it is the largest oil market in the world with a refining capacity of approximately 16 million barrels per day (bbl/d).

Western Canada is the largest source of petroleum imports to the U.S., providing nearly 2 million $\mathrm{bbl} / \mathrm{d}$ of crude oil ( $\sim 2.5$ million $\mathrm{bbl} / \mathrm{d}$ total petroleum), which accounts for more than $20 \%$ of U.S. imports [73].

In Western Canada production is expected to increase from 2.9 million $\mathrm{bbl} / \mathrm{d}$ in 2009 to about 4.2 million $\mathrm{bbl} / \mathrm{d}$ by 2025 (according to the Canadian Association of Petroleum Producers, 3.5 million $\mathrm{bbl} / \mathrm{d}$ of this will be oil-sands-derived hydrocarbon). This increased production will require new pipe- lines to transport diluted bitumen and synthetic crude to downstream facilities in the Edmonton area for refining outside of Alberta ( $72 \%$ is currently transported). Products from Alberta and Saskatchewan are primarily delivered to the Midwest, British Columbia, Ontario,

California, and Washington; however, there are plans to target other markets as well [73].

TransCanada's Keystone XL Pipeline, combined with an existing pipeline, would bring more than 1.1 million $\mathrm{bbl} / \mathrm{d}$ to the U.S. and could deliver oil as far as Port Arthur and Houston, Texas [66]. In addition, a number of potential projects are proposed to transport oil to the British Columbia coast (Kitimat) with the primary purpose of meeting the growing Asian demand. Two pipelines are proposed for this purpose: the Kinder Morgan TMX Northern Leg and the Northern Gateway pipelines, with initial capacities of $400,000 \mathrm{bbl} / \mathrm{d}$ and $525,000 \mathrm{bbl} / \mathrm{d}$, respectively $[74,75]$. It should be noted that the TMX Northern Leg is in the early 


\section{WEC Energy Delivery}

planning stages and will go ahead only if demand warrants it and after completion of planned expansions to the existing Trans Mountain line's Westridge Terminal in Burnaby, British Columbia. There are also two proposals that would utilize rail to transport Alberta oil to the west coast.

Development of other oil reservoirs has been constrained by a lack of refineries, pipelines, and rail facilities. For example, additional pipeline is planned for the Bakken field, which spans parts of Saskatchewan, Montana, and North Dakota and is one of the fastest growing oil production areas in North America. To address this, TransCanada is planning pipeline $(65,000 \mathrm{bbl} / \mathrm{d})$ to connect these resources to the TransCanada's

Keystone XL Pipeline, while Enbridge will build another pipeline connection $(145,000 \mathrm{bbl} / \mathrm{d})$ to the Enbridge Pipelines Inc. mainline. Both lines are intended to transport crude oil to refinery markets in North America.
In the longer term, if the large quantities of oil shale in the basins of Colorado's Piceance, Utah's Uinta, and Wyoming's Green River and Washakie are developed, they will also require suitable pipeline infrastructure.

\section{$\mathrm{CO}_{2}$ Pipelines}

Currently, seven $\mathrm{CO}_{2}$ pipelines are operating or are nearing completion in the WEC. In addition to these seven major lines, there are at least five spur lines feeding small oil fields close to the main pipeline route [Figure 29]. These pipelines make up approximately $1,350 \mathrm{~km}$ ( $\sim 840$ miles), just over $23 \%$ of the commercial $\mathrm{CO}_{2}$ pipelines currently operating in the U.S. They transport $\mathrm{CO}_{2}$ from a combination of natural and industrial sources to aging western oilfields for enhanced oil recovery [76], which helps tap more than 90 billion barrels of trapped recoverable oil. These pipelines are not part of an

Figure 28.

Oil pipelines within the WEC. [M15]

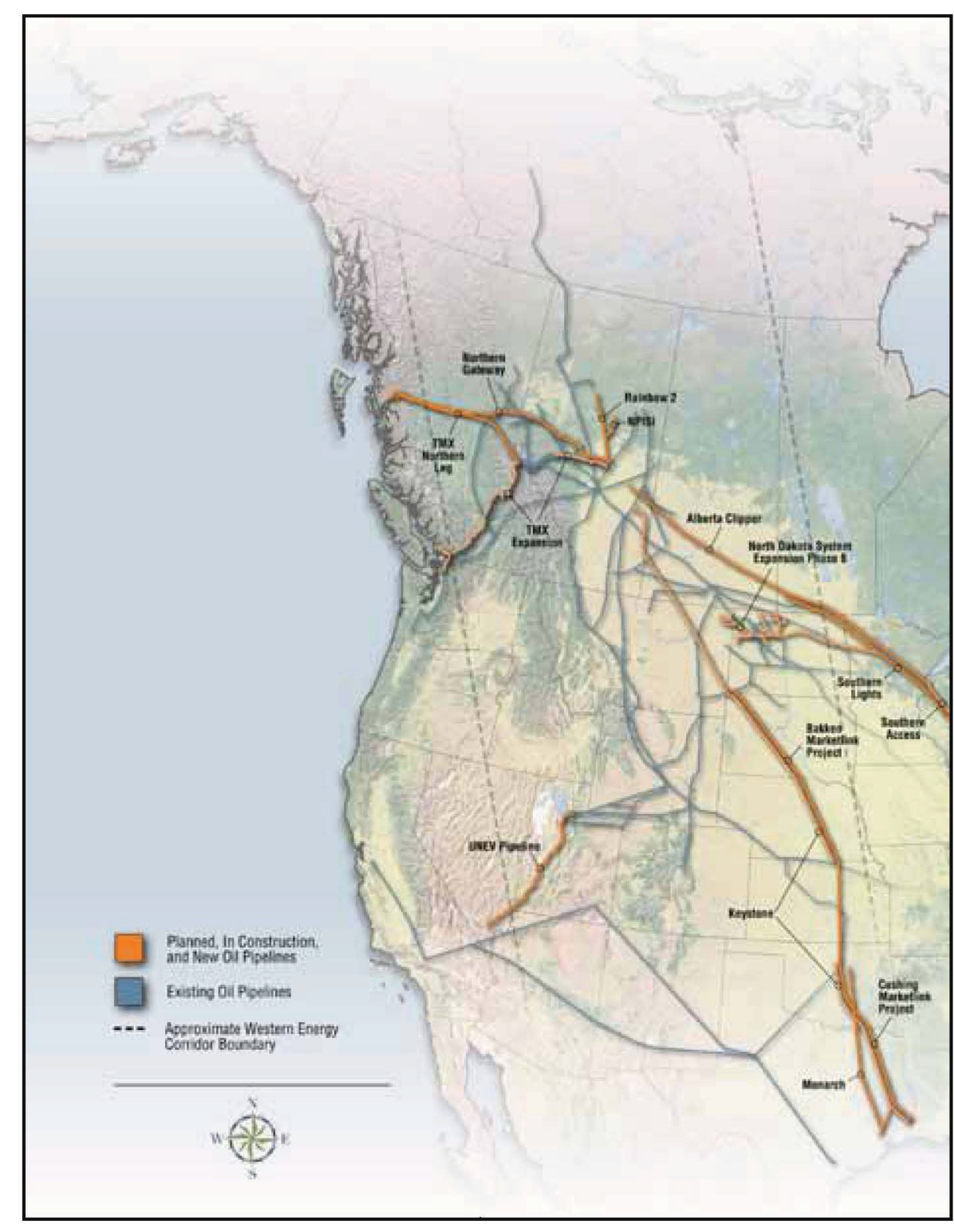




\section{WEC Energy Delivery}

integrated network. In fact, they have arisen in an ad hoc fashion determined by the economics of a given oil play, and the availability of government incentives. The major $\mathrm{CO}_{2}$ pipelines include the McElmo Dome Pipeline, which is over $800 \mathrm{~km}$ (500 miles) long and carries 1.1 billion cubic feet per day (BCFD) of $\mathrm{CO}_{2}$ to the Permian Basin and 60 million cubic feet per day (MMCFD) to McElmo Creek Utah; and the Greencore pipeline, which will go into production in late 2011, moving $720 \mathrm{MMCFD}$ $370 \mathrm{~km}$ ( 230 miles) from Wyoming to Southeast Montana.

New $\mathrm{CO}_{2}$ pipeline development projects are planned or underway in the WEC to increase $\mathrm{CO}_{2}$ use for enhanced oil recovery and to a lesser degree, to reduce $\mathrm{CO}_{2}$ emissions [Figure 29]. These projects are driven by a variety of objectives, including commercial, legislative, research, and regulatory interests. Alberta has initiated a \$2B CAN [76] effort to realize four major $\mathrm{CO}_{2}$ management projects. One project is the proposed north-south, 242-km ( $\sim 150$ miles) Alberta Carbon Trunk Line, which will gather $\mathrm{CO}_{2}$ from various operations and transport it to oil fields to the south to enhance oil recovery. Wyoming will add $\mathrm{CO}_{2}$ pipeline to capture emissions from the Lost Cabin Gas Plant in Fremont County, injecting it into oil wells in Encore's Bell Creek Field and eventually the Cedar Creek Anticline in southeastern Montana with the aim of increasing oil production from those fields.

Pipelines in the U.S. currently transport the $\mathrm{CO}_{2}$ needed to produce 237,000 barrels of oil per day domestically [77], with an additional 18,000-20,000 barrels per day produced by $\mathrm{CO}_{2}$-enhanced oil recovery (EOR) operations in southern Saskatchewan (most of which is sold to U.S. markets) [78]. With oil prices expected to be high for the foreseeable future, and the U.S. EPA regulating

Figure 29.

$\mathrm{CO}_{2}$ pipelines within the WEC. [M16]

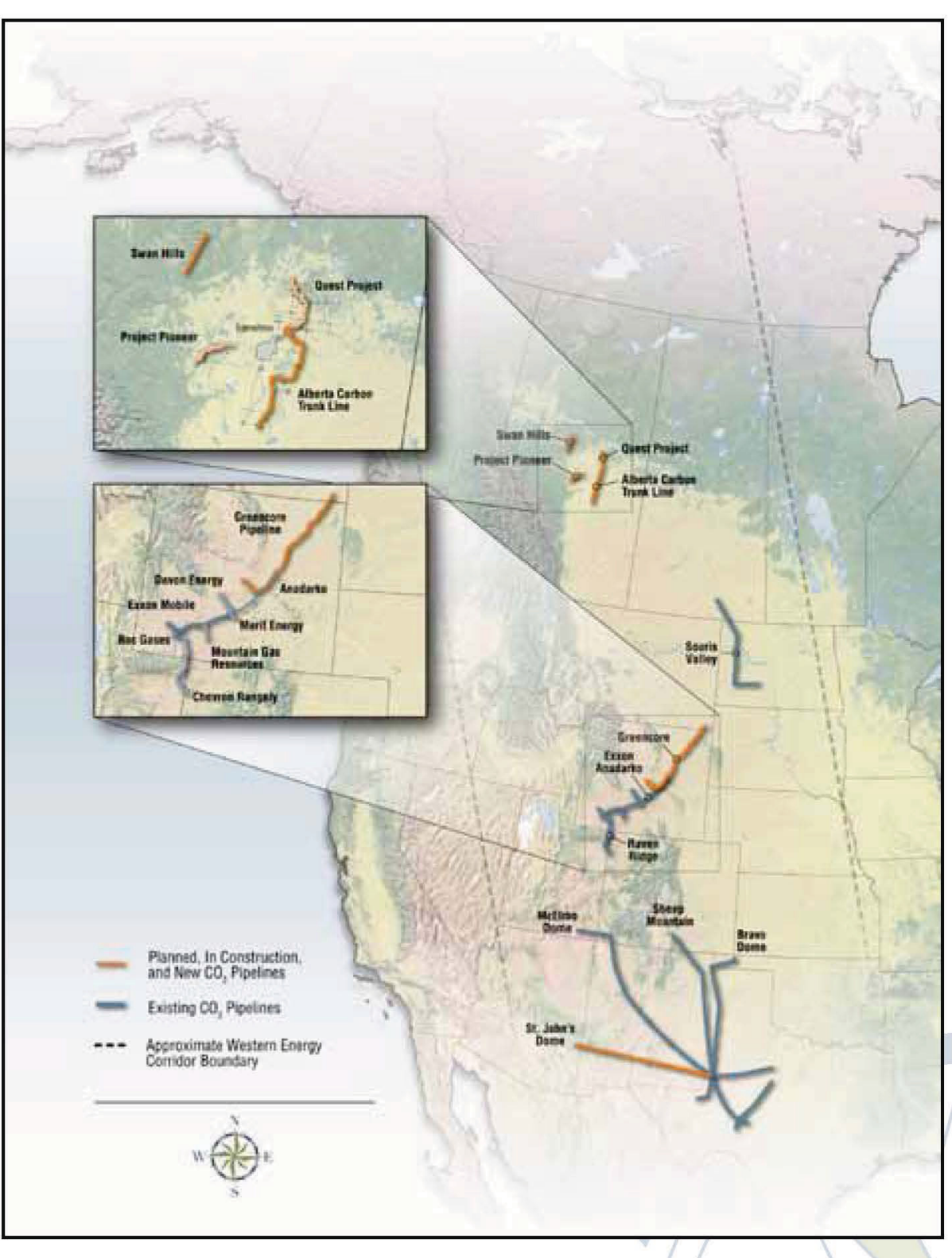




\section{WEC Energy Delivery}

carbon emissions, the need for $\mathrm{CO}_{2}$ pipelines will continue to grow. Although it has taken nearly four decades to bring the first 1,300 $\mathrm{km}$ ( $\sim 810$ miles) of pipelines into existence, economic and regulatory (emissions) drivers are likely to bring the next $1,300 \mathrm{~km}$ online much more quickly.

\section{Rail}

Railway transportation provides bulk movement of commodities such as coal, potash, agriculture products, and petrochemicals throughout WEC. This rail system provides either direct access or interconnecting rail to most of North America, and key connections to ports allow direct access to foreign markets. The WEC is serviced by five major railway companies, with Canadian Pacific Railway Company and Union Pacific Railroad acting as the primary providers. The three other major rail companies are Burlington Northern Santa $\mathrm{Fe}$, Canadian National Railway, and Utah Railway Company.
Coal is the single largest commodity moved by rail, a significant portion of which is moved within the WEC. Crude oil and refined petroleum products such as gasoline, diesel, and jet fuel are transported by rail to markets where pipelines are not available. Asphalt and fertilizer are typically transported by rail. With the expansion of the bioenergy industry, biomass transportation by rail is likely to increase. Distributed collection points for biomass products typically require a combination of trucking and rail and are most attractive for rail applications for long-distance markets.

Coal transport is driving rail expansion within the WEC. The 103-mile ( $165-\mathrm{km})$ Powder River Basin "Joint Line" is a dedicated coal railway, and it is one of the heaviest used rail systems in the world. Expansion is also being discussed to increase the movement of bitumen to markets (refineries

Figure 30. Railway lines. [M17]

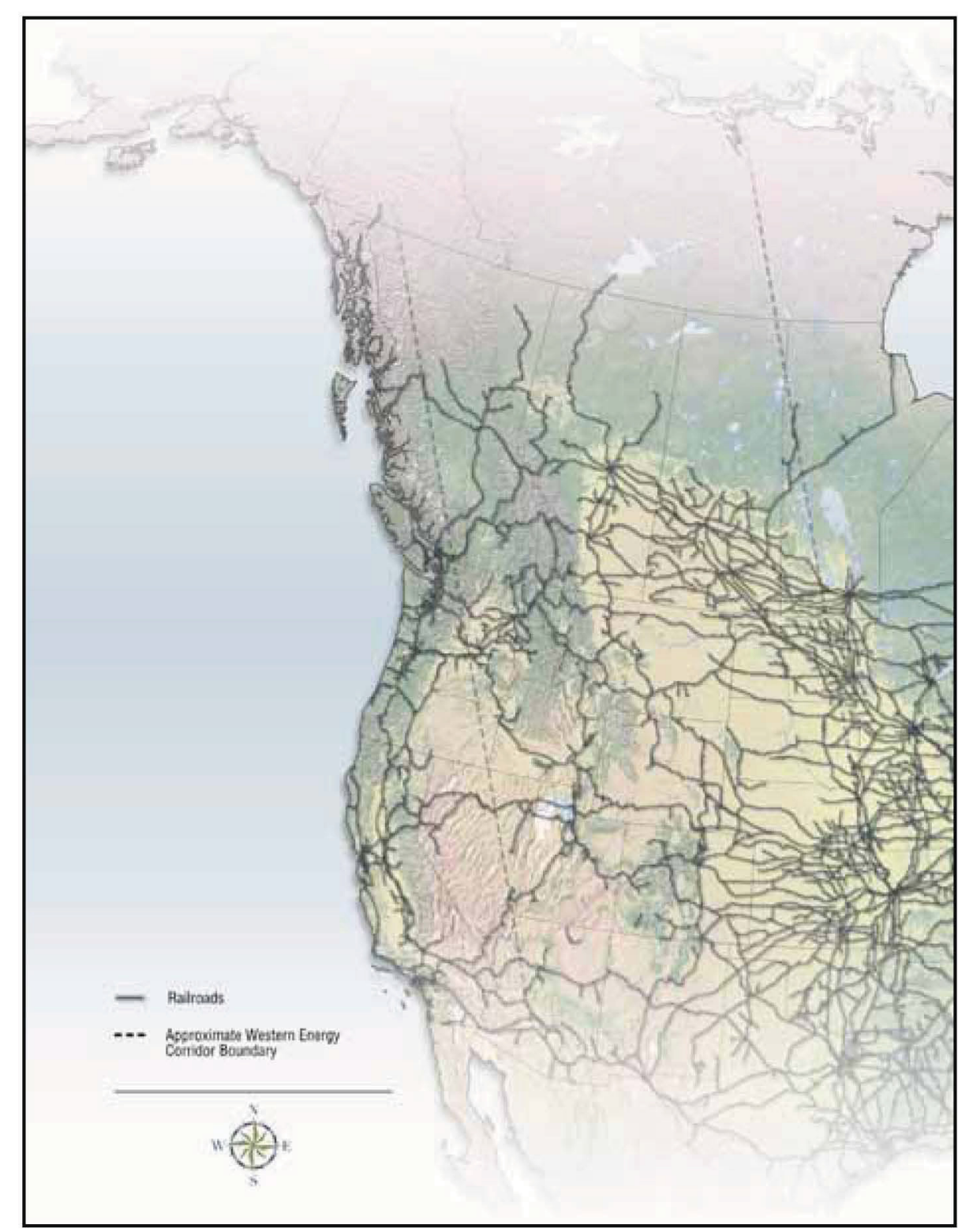


and terminals) where pipelines may not yet be available. Moving bitumen from the oil sands to various markets is an old practice with a new push for the rail industry to analyze whether it can offer a competitive alternative. Rail trans-

\section{Expanding and maintaining a healthy energy infrastructure}

\section{in the WEC is critically important to realize its energy and}

\section{economic potential.}

portation of LNG is being investigated by liquefaction companies as a means of moving energy to areas where pipeline infrastructure is not available. Although liquefying natural gas increases its energy density to the point at which large quantities of gas may be transported by rail, the overall economics of this process will ultimately determine the delivery method's viability. Similarly, development of the Bakken formation is driving evaluation of rail to transport oil to the Gulf of Mexico and the Great Lakes areas. 


\section{Energy and Environment}

$\mathrm{E}$ nergy development and the environment are inextricably linked in the Western Energy Corridor, and like all other human activity, energy development can affect the environment in numerous ways. Those energy-environment interactions need to be managed appropriately to ensure sustainable energy production. The WEC's rich energy resources will be fully unlocked only when environmental impacts are properly addressed [Figure 31]. The following section provides an overview of some of these impacts.

\section{Air}

Air quality concerns associated with energy production often focus on combustion by-products from coal-fired plants, including the emission of greenhouse gases ([GHGs]; carbon dioxide, nitrous oxide), criteria pollutants (nitrous oxides, particulate matter less than $10 \mu \mathrm{m}$, and carbon monoxide), and toxic air pollutants such as sulfur oxides and mercury. Another concern is winter ozone formation in high elevation basins believed to be associated with volatile organic compounds (VOCs) being released from gas fields. Along with GHGs, impaired visibility from engine emissions, suspension of dust from unpaved roads,surface mining operations, and coal cars are among the potential air-related impacts of energy production, especially given that the WEC contains parks and monuments that are protected by stringent visibility standards.

\section{Water}

Water is used extensively in energy development, and energy development can affect water supply and quality [79]. Depending on the energy technologies employed, significant quantities of water may be used in upstream processes (e.g., mining, pumping and processing fuels), the fuel combustion/energy generation process, and downstream processes (e.g., carbon cap-

Figure 31. Ecoregions within the WEC. [M18]

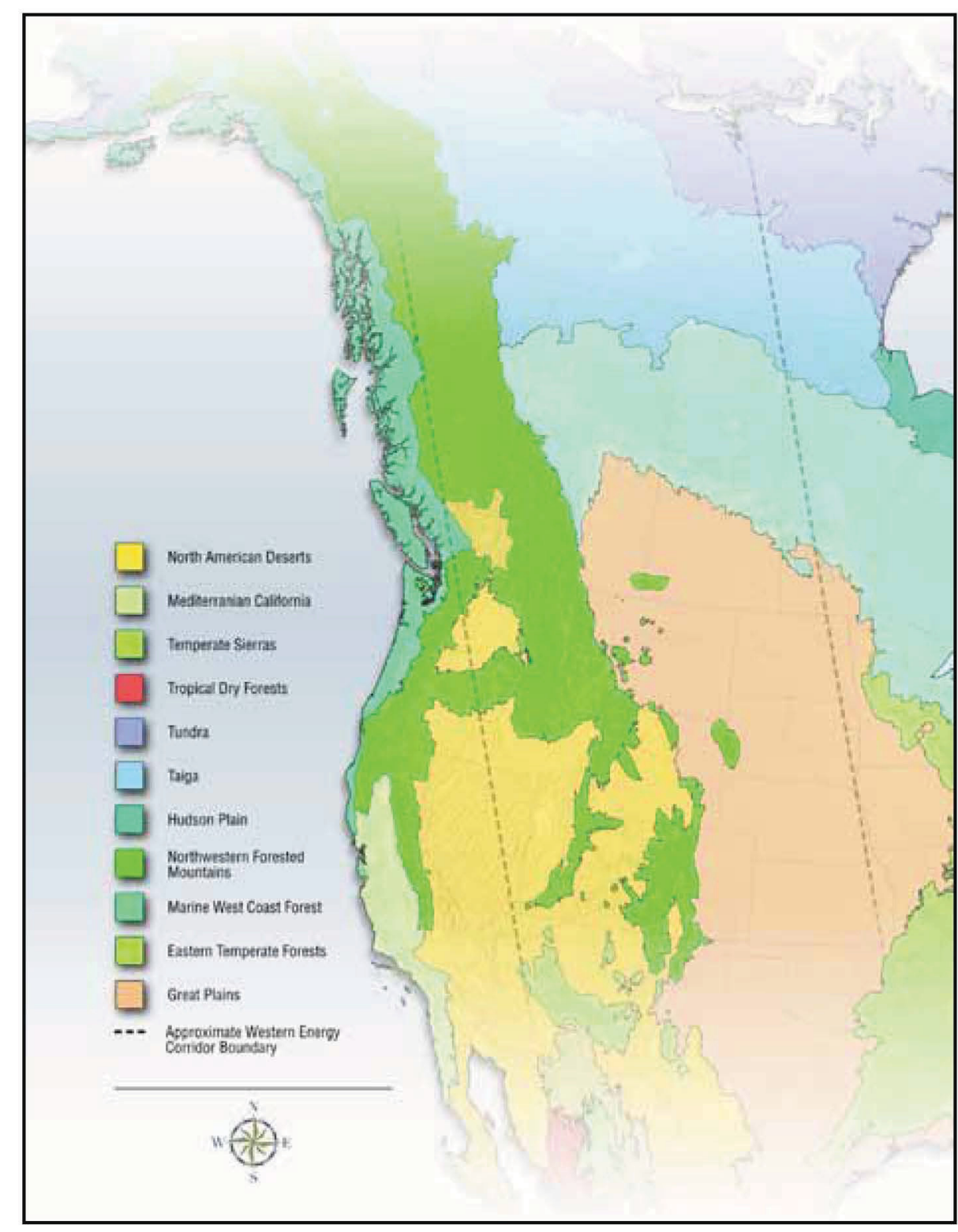


ture and sequestration) [80]. These concerns are especially important in the more arid portions of the WEC where water supplies are already fully or over-subscribed. Water quality concerns include emerging issues such as the potential for contaminating drinking water aquifer systems using hydraulic fracture or in-situ heating of oil sands or oil shale. In addition, there are growing concerns about the potential contamination of land and water resources by large tailings ponds and coal ash piles. Other concerns include potential pipeline releases that could cause oil spills into rivers and streams, pollution of the marine environment by increased oil tanker traffic off the British Columbia coastline that would be associated with the potential export of synthetic crude oil to Asia.

\section{Landscapes and Wildlife}

The WEC has some of the greatest expanses of undeveloped lands, including some of the finest national parks and monuments in North America along with a significant population of wildlife. The WEC encompasses a diverse range of landscapes, from high alpine parks and peaks to lowland playas and canyon lands and from wilderness to large cities [81]. Energy development within the WEC can have significant impacts on this landscape, critical to sustaining ecological zones, and fragmentation of such landscapes can have a negative impact on wildlife habitat and can disturb migration corridors [82]. Cumulative impacts from energy development along with other human activities (e.g., ranching and agriculture) on landscapes need to be planned and managed. It is important to take the long view because these ecological systems can be disturbed easily and take years to rehabilitate. Some examples of energy-landscape interactions in the WEC include energy production facilities, roads, drilling, transmission lines, pipelines, and dams.

\section{Climate Change}

Another environmental concern is the potential impact of energy development on the earth's climate. Fossil fuel combustion is a source of anthropogenic GHG emissions and potential contributor to climate change. Carbon dioxide $\left(\mathrm{CO}_{2}\right)$ is the primary GHG; however, other emissions such as methane and nitrous oxide, though produced in quantitatively smaller volumes, are actually more potent GHGs. The primary sources of GHG emissions in the WEC are the generation of electricity and the combustion of transportation fuels [83].

Relative to energy, coal-fired plants in the WEC are the largest $\mathrm{CO}_{2}$ producers; however, there has been a significant amount of debate relative to the impact of GHG emissions associated with oil sands development, which is estimated to contribute $6 \%$ of Canada's GHG emissions [84]. An example of a potential regional concern is the projected hydropower impact of climate change on snow accumulation and runoff [85]. To address this and related concerns, the federal governments and numerous WEC members have been pursuing the development of relevant climate change mitigation and adaptation policies, addressing energy efficiency, improving energy generation processes, and assessing carbon capture and sequestration alternatives.

Concerns have caused increased consideration of lower GHGemitting energy production options, such as renewable and nuclear energy and lower carbon fossil energy resources like natural gas. Natural gas produces fewer $\mathrm{CO}_{2}$ emissions per equivalent energy unit than oil or coal. However, methane, the main component in natural gas, is a much more powerful GHG than $\mathrm{CO}_{2}$. If natural gas is to become the preferred fuel for electric power generation, transportation, and industrial applications, leakage during production, transport, and consumption will likely need to be addressed. Cogeneration, the coproduction of heat and electricity, can improve the efficiency of natural gas generation, helping to reduce GHG emissions through lower fuel source consumption. Between 2001 and 2010,2,349 MW of installed cogen capacity has been added to Alberta's grid $[86,87]$. 


\section{Energy-Resource Nexus}

$\mathrm{T}$ he WEC is host to significant natural resources, many of which are not used for energy but have economic value to the region, and require energy for their development. The availability of reliable energy at competitive prices becomes a driving factor in investment decisions to develop non-energy natural resources native to the WEC. A few examples of this type of interdependence are offered below.

\section{Agriculture}

The WEC produces many agricultural commodities, with wheat and corn dominating both acreage and revenues $[88,89]$. General trends in all WEC crops are increasing commodity prices and farm income, driven by both rising world population and increasing per

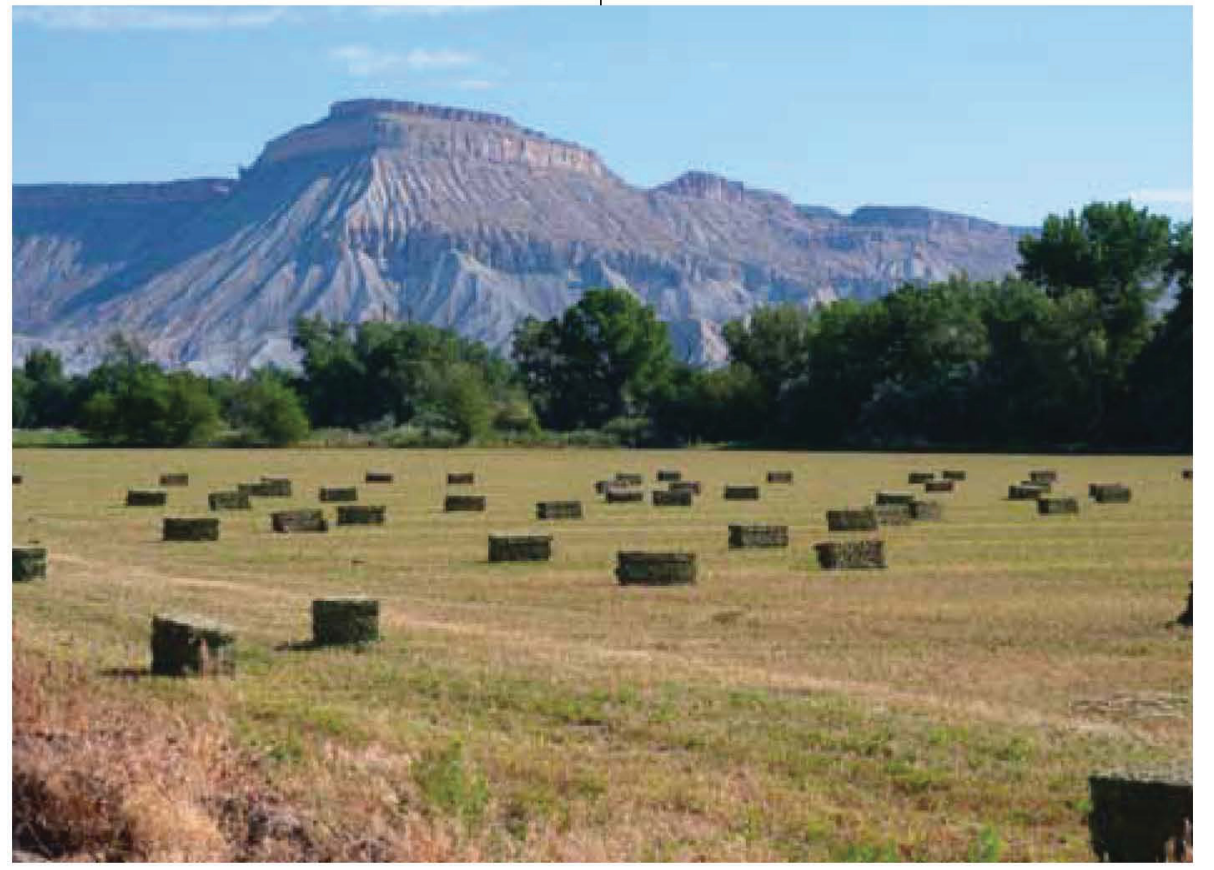

capita caloric intake in emerging markets [90]. A significant factor in the rising costs of producing these commodities is both "direct" and "indirect" energy use [91].

Direct energy consumption includes actual on-farm energy consumption such as running pumps or farm machinery or powering food-processing plants. Indirect energy consumption includes energy consumed to deliver farm products to market as well as energy consumed in off-farm production and delivery of goods consumed on the farm, such as producing fertilizers and pesticides. Increases in both direct and indirect energy uses increase production costs. However, indirect consumption costs may be more volatile and have a greater impact on agricultural production costs, depending on factors such as nutrient needs of the crops being produced and input costs such as fertilizer and pesticide production. A critical evaluation of energy use in agriculture could reveal ways to improve efficiencies that would increase farm incomes and/or offset the effects of future energy price volatility or sustained increase.

Other interdependencies that have emerged between energy and agriculture include the use of agricultural lands for energy production, i.e., for the biofuels market, rather than for food production. Relationships developing between ranchers and wind energy developers can optimize the land use.

\section{Fertilizer Production}

The WEC produces significant quantities of the major plant fertilizer nutrients, e.g., nitrogen, phosphate, and potash [92]. Of these nutrients, nitrogen is used in the greatest quantity and accounted for $56 \%$ of the U.S. usage of chemical fertilizers in 2005 [93]. The value of these nutrients and the companies that produce them has risen dramatically recently in response to rising demand for food, particularly as wheat and corn production have increased [90]. Several forms of energy are consumed by the fertilizer industry, including 


\section{Einergy-Resource Vexus}

natural gas for plant operations (e.g., producing process heat) and the consumption of petroleum for product delivery. However, natural gas is the key ingredient used to produce hydrogen and provide energy for ammonia production, which is in turn the key ingredient in nitrogenous fertilizer production. Natural gas amounts to more than half of the input costs (in some cases 75 to $90 \%$ ) for nitrogenous fertilizer production and delivery. Understanding how the costs of fertilizer production, especially the energy costs, can be reduced would help assure WEC competitiveness in the agricultural industry and could open markets around the world for improved WEC fertilizer technology.

\section{Water Resources}

WEC water resources are critical for energy development, as well as for other regional resource development mentioned in this section. Water is used to fracture tight geologic formations (e.g., shale) to recover oil and gas. It is also commonly used to cool thermal power plants, so it is important to ensure an adequate water supply exists prior to construction of power plants, whether nuclear, fossil, or solar thermal. Air cooling is becoming more common, but it is more expensive and plant efficiency is generally lower.

Another example of water use is in the steam-assisted gravity drainage (SAGD) process, in which steam is injected through horizontal wells to help recover viscous bitumen from the oil sands. Of course, water also plays a direct role in the generation of hydroelectricity, and it is critical in many areas for the irrigation and processing of bioenergy crops [94]. Characterizing the value of water in these applications, and understanding what alternative processes could reduce the use of water, are first steps towards reducing risks associated with long term energy investments.

\section{Fossil Energy Development}

Fossil energy development may require substantial external energy inputs derived from other energy sources. Examples include, in-situ

\section{It takes energy to make energy}

coal gasification where part of the coal is oxidized to provide heat. Large-scale production of oil from oil shale using in-situ electric heating to recover kerogen would require a significant quantity of electricity. Currently, large quantities of natural gas are burned to generate heat for thermal bitumen recovery from oil sands, and upgrading of the produced oil depends on the use of natural gas for heat and hydrogen. As a final example, recent studies have been conducted [95] on the use of nuclear energy to provide not just electricity, but also heat for the production of oil from oil shale, steam for the production of oil from oil sands, and hydrogen to upgrade the oil produced from oil sands and oil shale. Nuclear energy could also produce oxygen for coal gasification and coal combustion. There are significant opportunities for further exploring the application of integrated en- ergy systems, built upon regionally available energy resources that would potentially result in greater efficiencies and better stewardship of WEC resources. 


\section{Influences on WEC Energy Development}

$\mathrm{E}$ nergy development and use in the WEC is influenced by a number of regional, North American, and international driving forces. These are complex, hard to predict with any reliability (especially over the decades-long time scales of energy projects), and difficult to reconcile. Nonetheless, these driving forces will be part of the broad environment in which energy projects must operate. Selected factors are discussed below.

\section{Demand}

Demand for energy resources from the WEC - for reliable power, heat, and transportation - will expand with North America's population and economic growth. As demand grows, consumption efficiency will increase as well as the need for more electricity capacity within North America. For example, the U.S. electricity demand is anticipated to grow by $31 \%$ (an average of $1 \%$ per year), from 3,745 billion kilowatt-hours in
2009 to 4,908 billion in 2035 [96] In addition, continued demand for transportation fuels will require continued U.S. import of millions of barrels of oil, despite efforts to reduce imports by making vehicles lighter and more efficient, substituting biofuels for fossil fuels, and using electric vehicles [97]. Also, energy-intensive industries within the WEC, such as oil sands recovery and processing, will require more natural gas to meet production goals. Demand is growing in Asia as well - China in particular, is projected to be a dominant energy consumer in 2035. This will drive demand for certain WEC resources, such as oil, natural gas, coal and uranium. Figure 32 shows these projections for electricity generation in the U.S.

Figure 32.

U.S. Electricity generation by fuel type, for 2007, 2009, and 2035 (billion kilowatt-hours). [13]

\section{Energy Supply}

The WEC contains rich, diverse, and sustainable supplies of worldclass energy resources strategic to North America's electricity and fuels needs, as well as the growing needs in Asia. Unconventional oil and gas resources in the WEC are large enough to meet many of North America's needs for the foreseeable future as production from conventional oil and gas supplies decline. The WEC's vast coal reserves will continue to supply North American electricity- generation needs for the long-term; however, the use of natural gas for electric power generation is expected to increase relative to coal [97]. The WEC is also well positioned to supply significant amounts of renewable energy (if accompanied by integrating infrastructure), especially from hydro and wind power. Uranium will continue to meet North American and international demand, and additional development within the WEC is anticipated, given the 2013 cessation of the United States using nuclear fuel derived

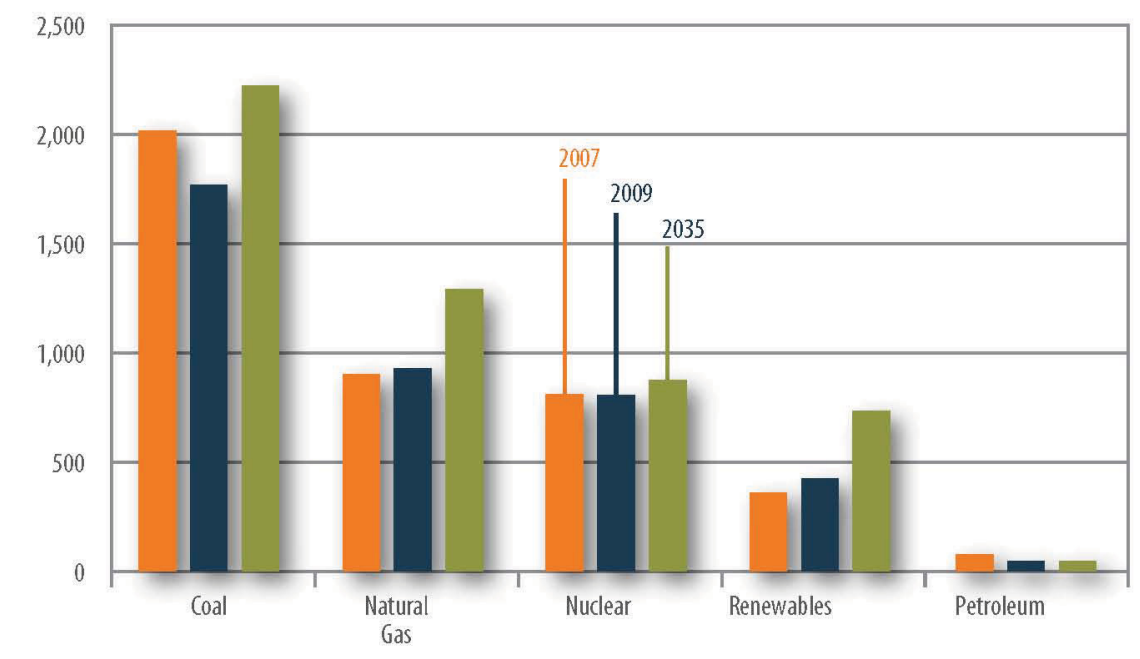


from dismantled Russian nuclear warheads.

\section{Energy \& Environment}

WEC energy resource development and use are increasingly influenced by policy that leads to regulating impacts on the environment. For example, existing or proposed $\mathrm{CO}_{2}$ emissions standards drive investment decisions related to electric power generation, particularly the investment in, or decommissioning of coal-fired power plants.

Relative to Alberta oil sands, the Government of Alberta recognizes the great importance of balancing environmental sustainability and economic development. One last example is concern about 1 ) the impacts of exporting oil or coal to China, which has generated renewed scrutiny of oil tanker traffic off the coast of British Columbia, and 2) the U.S. export of coal to Asia from Washington and Oregon terminals.

\section{Existing and Emerging Export Markets}

The WEC will continue to grow its energy exports to both traditional and nontraditional U.S., Canadian, and Asian markets. As an example, Alberta is fast becoming the largest provider of oil to the U.S., relative to countries outside North America, because of its increasing production from oil sands.

Canadian natural gas exports to the U.S. may be impacted by the need to supply oil sands processing activities, deliver exports to Asia, and respond to the growing shale gas boom in the U.S. [98]. Another emerging export opportunity is to provide electricity from renewable energy sources to markets in the west and southwest U.S., helping meet their renewable energy mandates. Electricity export will also help international north-south trade, especially with the significant hydropower potential in the northern portion of the WEC. Current market conditions and policy settings are driving WEC states and provinces to explore greater export of coal, diluted bitumen, synthetic crude oil, and natural gas to Asia.

\section{Price}

The price of energy has significant impact on energy development investments. High oil prices and low volatility, for example, encourage unconventional and high-risk commercial developments, as well as R\&D investments aimed at improving exploration success and increased recovery. Another example is the impact on natural gas prices of the recent boom in unconventional shale gas, which has resulted in certain WEC provincial partners to seek alternative markets in Asia, and associated investment in building $L N G$ processing facilities and export terminals in British Columbia. The current low price of natural gas, along with the relatively low capital cost of building natural gas power plants, currently enhances the attractiveness of gas for electricity generation.

\section{Investment}

Because of the massive scale of energy production, transportation and use, and the benefits of "economies of scale," energy infrastructure is large and expensive - new project costs tend to be measured in billions or even tens of billions of dollars. Direct foreign investment in WEC fossil energy resources by Asia-Pacific countries has been increasing through cross-border mergers and acquisitions [99]. Governments also have provided incentives for energy investment. For example, Alberta invested part of its income from royalties in energy innovation, which enabled the subsurface extraction of oil from oil sands. Another type of investment includes subsidies. To encourage investment in renewable energy, subsidies have become an increasingly important form of government intervention. 


\section{Infrastructure}

The availability of infrastructure to process and deliver energy and to increase system reliability and efficiency is critical to unlocking WEC energy resources and inter-jurisdictional trade. Lack of infrastructure has driven certain development decisions. For example, because of insufficient refining capacity in Alberta, much of the synthetic crude oil produced there will be sent to U.S Gulf States for refining. Another example is the need for natural gas, diluted bitumen, and synthetic crude oil pipelines to export terminals along the British Columbia coastline to support diversification to Asian markets. One last example is the lack of suitable electrical transmission and storage needed to better integrate and deliver vast, but highly variable, wind power in the area, as well as support crossborder movement of electricity. In this case, substantial advances in storage and transmission technologies are needed before large-scale deployment throughout the WEC would be economically competitive and publicly acceptable.

\section{Technological Innovation}

Technological innovation has been a key driver in developing energy resources within the WEC, such as the application of SAGD to the extraction of oil sands and hydraulic fracturing technology applied to unconventional gas extraction. This constant improvement in technology will be required to further develop energy resources within the WEC, especially as conventional energy resources are depleted. Technological innovation is also critical to mitigate environmental consequences associated with energy development.

Of note is Alberta's considerable investment in energy technology innovation, beginning with oil sands development technology, $\mathrm{CO}_{2}$ management, and water treatment associated with oil sands tailings ponds. Another example is the number of innovative in-situ oil shale retort processes being developed to lessen environmental impact. The deployment of new technology carries risk, and prototype demonstrations are needed to reduce the risk for industry and investors while gaining regulatory and public acceptance. Given the resource wealth and associated technological challenges within the WEC, there is an opportunity for the WEC to lead internationally in technology development, demonstration, and deployment. 
In addition to the 34 academic establishments, the region has ten major non-academic institutions with missions relevant to energy resources: four U.S. government laboratories, one Canadian govern-

typically has government agencies dedicated to researching various energy resources and generation.

These institutions can play a significant role in increasing produc-

\section{Industry relies on an educational system with strong and}

\section{active research and development talent. The WEC has a}

\section{unique set of top research institutions to leverage in its}

\section{energy development endeavors.}

ment laboratory, three independent research organizations, and two provincial organizations in Canada. All ten are oriented towards applied research and the development of commercial applications. This list of research organizations does not include any corporate research facilities dedicated to the problems of one company. Neither does it include the many focused research programs or centers that operate within individual universities or that are partnered with universities and corporate research groups. Each state and province also tivity and improving the economics of further developing the WEC's vast energy resources. Collaborations between these institutions, industry, and the private sector could yield long-term academic programs in highly specialized energy topics.
Figure 33.

Research institutions.

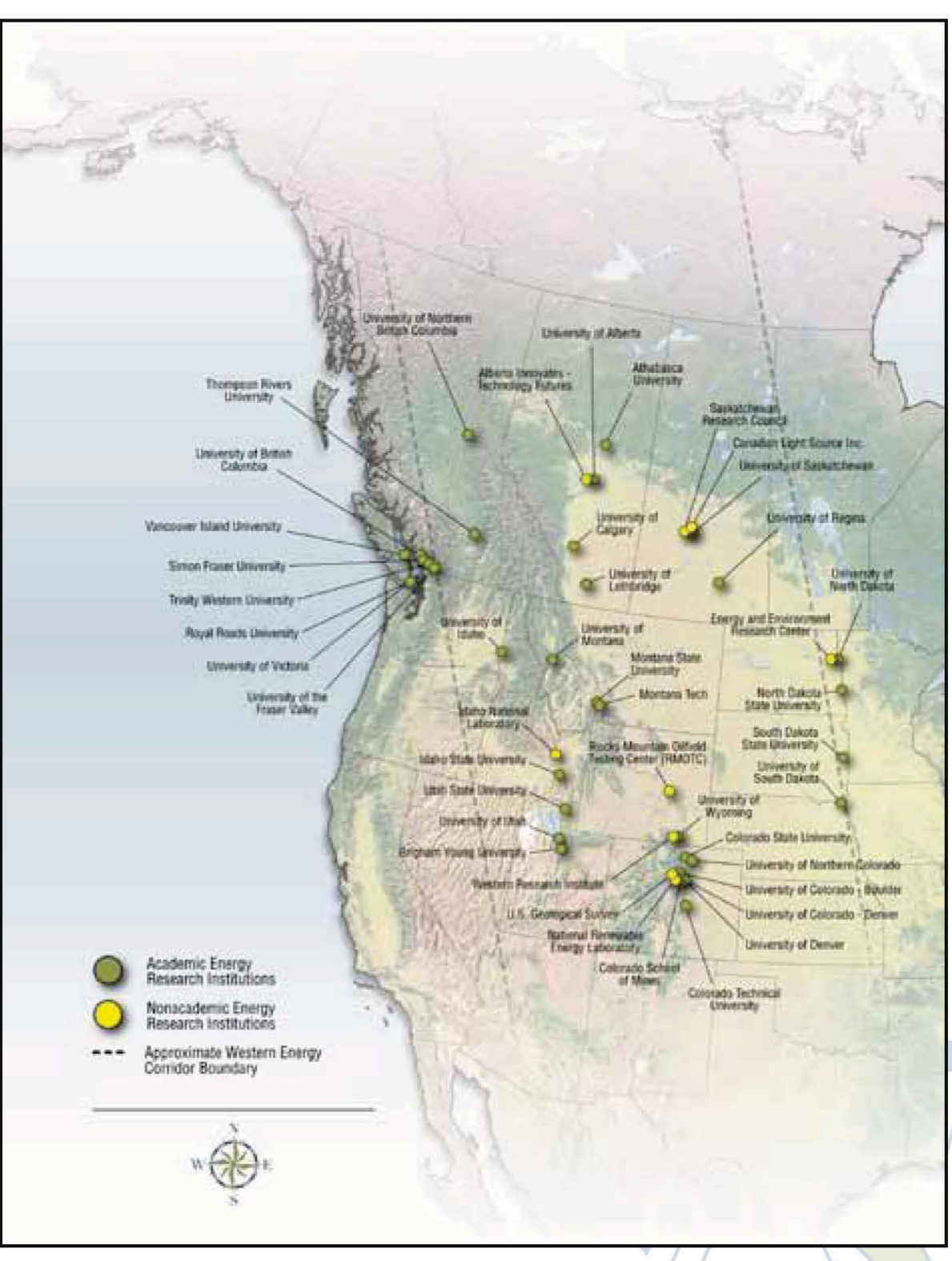




\section{Summary}

$\mathrm{E}$ nergy Resources. The WEC is a source of enormous quantities of fossil, renewable, and nuclear energyrelated resources that will well serve the energy security needs of the region and North America for the foreseeable future. It is not just the vastness of these resources that is important, but also their collective diversity and projected longevity. Increasingly, there will be greater dependency on these resources for electricity and fuels throughout this century. Given this platform of energy resources and other natural resources, there is great potential to create valueadded industrial enterprises. This setting will also be necessarily influenced by emerging overseas energy demand, in particular from Asia.

Crude 0il. WEC oil resources currently play a significant role in meeting both U.S. and Canadian demand, primarily associated with transportation fuels. WEC crude oil proven reserves in 2009 are collectively estimated at approximately 175 billion barrels, placing the WEC third in world ranking. These reserves are dominated by unconventional oil resources, such as the Canadian oil sands in Alberta and Saskatchewan, which are projected to experience significant growth in production and comprise a greater proportion of imports in the U.S. The oil sands production is supplemented by significant production from the emerging Bakken formation development in the Williston Basin. In the longer term, there is tremendous potential associated with vast oil shale resources located in Utah, Colorado and Wyoming. Reliance on WEC crude oil supplies will only increase and they can potentially lessen dependence on oil imports from economically and politically unstable countries.

Natural Gas. Natural gas production in the WEC places it third behind Russia and the U.S. in world ranking. The current North American natural gas production boom is exemplified within portions of the WEC, where shale gas, tight gas and coal bed methane are plentiful. The current abundance and low market price of natural gas and its associated lower $\mathrm{CO}_{2}$ emissions, has led to its current favor as a feedstock for fossil electricity plants. The resulting natural gas market conditions are encouraging British Columbia and Alberta to invest in conveying natural gas to the British

Columbia coastline where it can be converted to LNG and shipped to Asia, where market prices are higher. The gas production boom has also inspired renewed interest in natural gas as a transportation fuel; however, this path has not yet been fully developed.

Coal. The WEC contains excellent coal reserves upon which much of North America is currently heavily dependent for electricity production. WEC coal production in 2009 approximated about $8.2 \%$ of world production and about $54 \%$ of the combined U.S. and Canada production. Demand projections through 2030 suggest coal will continue to play a foundational role within North America, greatly contributing to the generation of relatively low-priced, base-load electricity. For coal seams too deep to mine, in-situ coal gasification is being introduced in Alberta, which converts coal to a syngas used to fuel combined cycle gas turbines to generate electricity. The current combination of available low-priced natural gas and existing or proposed environmental policies is influencing investment decisions relative to building new coal plants; however, in the long term, coal will remain a crucial component of the North American energy mix.

Renewable Energy. The headwaters of some of North America's greatest rivers are located within the WEC, and produce a significant amount of hydropower both within and outside the WEC. In 2009, 90 million MWh of electricity - approximately $24 \%$ of the WEC's total electricity generation that year - was generated from hydropower in the WEC. Much of this resource 
potential has already been tapped within the WEC, in particular south of the U.S.-Canadian border. However, there is significant potential for additional power, such as lowhead hydro and larger scale dam projects, with the latter opportunity more likely to occur in the northern portion of the WEC.

The WEC also hosts some of the highest wind potential regions in the North America, which are increasingly being used for electricity generation. In addition, the WEC includes some of the most productive croplands and forestlands, which are potential feedstock sources for biofuels. Minor enterprises associated with geothermal, solar, and ocean/tidal energy potential also operate in the WEC.

Uranium. The WEC hosts substantial amounts of uranium, much of it of high grade, which is used to fuel North American and international nuclear power plants. Saskatchewan deposits dominate the WEC (and North American reserves), and in 2009 the Saskatchewan produced $18 \%$ of the world's uranium. The McArthur River Mine, located in Saskatchewan, is the largest uranium producing mine in the world with 7,654 metric tons of uranium produced in 2009 , approximately $14 \%$ of the world's uranium production. Demand for uranium within the WEC may increase, given that half of the nuclear fuel currently used in the U.S. is derived from dismantled Russian nuclear warheads, and this program will be halted in 2013 .

Other nuclear energy related assets are emerging in the area, such as a uranium enrichment plant to be located in Idaho.

Electric Generation. Abundant gas, coal, and hydropower resources within the WEC enable the region to supply some of the lowest priced electricity in North America. In 2009, the WEC's electric power generation capacity was estimated at over 76,000 MW, and total electrical power generation within the WEC in 2009 was 370 million MWh. Of this genera- tion, about $70 \%$ came from fossil fuel plants, (primarily from coal and natural gas), $24 \%$ from hydropower, and approximately $4 \%$ from other renewables, with the latter expected to increase. The WEC does not currently host any operating commercial nuclear power plants (NPPs), but there have been emerging interests to add NPPs to energy portfolios of certain states and provinces.

Liquid Fuels Generation. The WEC hosts energy resources that can contribute to development of conventional and unconventional liquid fuels. As of 2009 , nearly 30 crude oil refineries with a 1.3 million barrel per day total operable capacity are located within the WEC. The WEC also has several oil sands and heavy oil upgraders in Alberta and Saskatchewan with a total operable capacity to produce 1.2 million barrel per day of synthetic crude oil. A recent "game changer" is the proposed LNG production to facilitate export of British Columbia and Alberta natural gas to Asia.
The WEC is also part of the emerging biofuels industry, which could help lessen selected imports of oil to the U.S. In 2009, the collective operating capacity was approximately 2,000 million gallons (50 million barrels) per year. Coal-toliquids is another potential transportation fuel source to be introduced in the WEC with a newly planned operation in Wyoming and another proposed in Utah. In the longer term, oil shale can also contribute to the production of unconventional liquid fuels. Finally, there is renewed interest in using natural gas as a transportation fuel, but it is yet uncertain how this opportunity will emerge.

Energy Delivery. Expanding and maintaining a healthy energy infrastructure in the WEC is critically important in realizing its energy and economic potential. A large number of infrastructure projects are currently being pursued, some of which have already been mentioned, but are included below for completeness: 
- Large investments are being made in association with the planned expansion of oil sands production. This will require substantial increases in the amount of oil recovered via both mining and subsurface recovery, increased use of natural gas to produce hydrogen and steam, increased upgrading capacity via new construction and expansion of existing capacity, and new pipeline to export synthetic crude oil to refineries and new markets, including Asia.

- Also associated with the Asian market is the current drive to build a natural gas pipeline to export LNG by tapping Alberta and British Columbia's unconventional natural gas fields and transferring natural gas to the British Columbia coastline.

- Associated with the oil production boom in the Bakken formation, efforts are underway to supply new pipeline to connect the oil resources to major oil pipeline and rail in the vicinity for export to refinery infrastructure.

- Large investments continue to be made within the WEC to convey $\mathrm{CO}_{2}$ to various depleted oil fields, where it can enhance oil recovery processes, and sequester carbon.

- Developing new electrical transmission infrastructure is critical to capturing the enormous potential associated with WEC renewable energy resources located in more remote areas, and to better integrate and balance electrical supply and demand between different areas and from different types of electricity generation.

- Sufficient infrastructure will be paramount for more integrated and efficient resource development and use, at various scales, i.e., at plant, community, and regional scales.
Energy and Environment. Significant concerns on a number of levels relate to the potential impacts of energy development on the environment within the WEC. Areas of concern include impacts on air, water, landscape and wildlife, fisheries, and climate change. Environmental regulations are increasingly imposed on energy development and use, but at the same time, new technology and innovation are enabling energy companies to produce energy more efficiently and with less environmental impact. As a result, environmental concerns are increasingly addressed as part of the energy development life cycle. Striking the right balance between protecting the environment and producing enough energy at a competitive price will be critical for the economic and social development of the WEC. For example, Saskatchewan has led $\mathrm{CO}_{2}$ management research and Alberta recently invested in building the largest carbon capture project in the world.
Energy - Resource Nexus. The

WEC contains a variety of natural resources important to the regional economy and interdependent with regional energy resources. These include agriculture, water, fertilizer, and other minerals. Development and/or use of these resources requires energy input in various forms (electricity, heat, fuels) and intensity levels. Energy resource development is itself energy intensive, especially recovery of fossil fuels from unconventional resources. Energy development may also require use of other natural resources as well, including water, agricultural feedstock, etc. Optimal integration of WEC resources may provide opportunities leading to efficient production of greater economic value.

Influencing Factors. A number of factors influence energy development and use within the WEC, including supply and demand, export schemes, energy pricing, investment, technology innovation, environment, and infrastructure. Understanding these factors and 
their interactions can help WEC stakeholders develop a framework attractive to investors who can finance energy development projects. Of particular note is the growing Asian demand for WEC resources such as oil, natural gas, coal, uranium, and fertilizer. This demand is expected to have a major bearing on WEC export strategy and on direct Asian investment in certain WEC resources and associated infrastructure.

Research Assets. Technological innovation has been a major game changer within the WEC - for example technology innovation, sustained over many years has resulted in competitive technologies for extracting oil from sands and gas from shales and mudstones on very large scales. Technological innovation will continue to be a key factor in developing WEC energy resources. Significant research assets that can contribute to addressing the various energy development challenges in the region are located within the WEC. These assets include expertise and labora- tory facilities found within regional universities, government laboratories, and independent research organizations. And the significant contribution from corporate-sponsored research can be expected to grow rapidly as more hydrocarbon is produced from unconventional sources in the WEC. 


\section{Appendix A - References}

[1] CCEI, 2011, "Energy Facts \& Statistics, Canada - Statistics," Canadian Centre for Energy Information, http://www. centreforenergy.com/FactsStats/ Statistics.asp?Template $=5,0$, accessed May 2011.

[2] CAPP, 2011, "Canada's Oil Sands - The Reality," Presentations and Speeches, Canadian Association of Petroleum Producers, http://www.capp.ca/library/ presentations/Pages/default. aspx\#QrouKpvEESwu,presented May 4, 2011, accessed May 2011.

[3] USGS, 2008, "National Assessment of Oil and Gas Fact Sheet, Assessment of Undiscovered Oil Resources in the Devonian-Mississippian Bakken Formation, Williston Basin Province, Montana \& North Dakota, 2008," U.S. Geological Survey, 2008-3081, http://pubs. usgs.gov/fs/2008/3021/pdf/FS083021_508.pdf, published April 2008, accessed May 2011.

[4] Kohn, J., 2011, "USGS plans new assessment of Bakken oil formation," KTVQ. http://www. ktvq.com/news/usgs-plansnew-assessment-of-bakken-oilformation/, posted May 19, 2011, accessed June 2011
[5] North Dakota Industrial Commission, n.d., "Industrial Commission of North Dakota Oil \& Gas Division 2010 Monthly Statistical Update," https://www.dmr.nd.gov/oilgas/ stats/2010monthlystats.pdf, accessed June 2011.

[6] Energy Resources Conservation Board, June 2011, Alberta's Energy Reserves 2010 and Supply/Demand Outlook 20112010. http://www.ercb.ca/docs/ products/STs/st98_current.pdf.

[7] Energy Resources Conservation Board, June 2010, Alberta's Energy Reserves 2009 and Supply/Demand Outlook 20102019. http://ercb.ca/docs/products/ STs/st98_2010.pdf.

[8] BLM, n.d., "[2008] Oil Shale $\&$ Tar Sands Programmatic EIS Information Center: About Tar Sands," Department of the Interior, Bureau of Land Management, http://ostseis.anl. gov/guide/tarsands, accessed June 2, 2011 .

[9] Johnson, R. C., T. J. Mercier, M. E. Brownfield, and J. G. Self, 2010, "Chapter 1, Assessment of in-place oil shale resources in the Eocene Green River formation, Uinta Basin, Utah and Colorado,"
U.S. Geological Survey Digital Data Series, DDS-69-BB, 162p.

[10] U.S. Department of Energy, Office of Petroleum Reserves, Strategic Unconventional Fuels, 2011, "Fact Sheet: U.S. Oil Shale Resources," http://www.fossil. energy.gov/programs/reserves/ npr/Oil_Shale_Resource_Fact_ Sheet.pdf, accessed May 2011.

[11] Utah Heavy Oil Program (UHOP), 2007, A Technical, Economic, and Legal Assessment of North American Heavy Oil, Oil Sands, and Oil Shale Resources, Report prepared for the U.S. Department of Energy, http:// fossil.energy.gov/programs/ oilgas/publications/oilshale/ HeavyOilLowRes.pdf, published September 2007, accessed May 2011.

[12]EIA, 2011, Annual Energy Outlook 2011 with Projections to 2035, U.S. Energy Information Administration, DOE/EIA0383, http://www.eia.doe.gov/ forecasts/aeo/pdf/0383(2011).pdf, published April 2011, accessed May 2011.

[13]EIA, 2009, "International Energy Statistics, Natural Gas Overview 2009 (Billion Cubic Feet)," U.S. Energy
Information Administration, http://www.eia.gov/cfapps/ ipdbproject/IEDIndex 3 .

cfm?tid=3\&pid=26\&aid $=24$, accessed May 2, 2011.

[14] Kuuskraa, V. A., 2007a, "The Unconventional Gas Resource Base," Oil \& Gas Journal, http://www.adv-res.com/ pdf/ARI $\% 200 G J \% 202 \% 20$ Unconventional $\% 20 \mathrm{Gas} \% 20$ Resource\%20Base\%207_24_07. pdf, published July 24, 2007, accessed May 2011.

[15]CAPP, 2010, "Canada's Shale Gas," Canadian Association of Petroleum Producers, www.capp.ca/GetDoc. aspx?DocID $=165107 \& D T=P D F$, slide presentation published February 5, 2010, accessed May 2011.

[16] EIA, 2001, World Shale Gas Resources: An Initial Assessment of 14 Regions Outside the U.S., U.S. Energy Information Administration, http://www. eia.gov/analysis/studies/ worldshalegas/pdf/fullreport.pdf, published April 2011, accessed May 2011.

[17]EIA, 2011, "Country Analysis Briefs: Canada," U.S. Energy Information Administration, 
http://www.eia.doe.gov/cabs/ canada/pdf.pdf, updated April 2011, accessed May 2011.

[18] Centre for Energy, n.d., "Energy Facts \& Statistics," Canadian Center for Energy Information, http://www.centreforenergy.com/ AboutEnergy/Coal/Environment. asp?page $=10$, accessed May 2011

[19] EIA, 2009, U.S. Coal Production by Coal-Producing Region and State,2008-2009, Production Tables, http://www.eia.gov/ cneaf/coal/page/acr/tables2. html, Energy Information Administration, updated February 3, 2011, accessed May 2011.

[20] Natural Resources Canada, 2009, "The Atlas of Canada - Coal Resources," http://atlas.nrcan. gc.ca/site/english/maps/economic/ energy/Coal, updated September 2, 2009, accessed May 2011.

[21]EIA, 2011, Wyoming Analysis, Energy Information Administration, http://www.eia gov/state/state-energy-profilesanalysis.cfm?sid=WY, updated October 2009, accessed May 2011.

[22] Coal Association Canada, n.d., "Coal Production by Type and Province," http://coal.ca/content/ attachments/article/62/Coal $\% 20$ Production $\% 20$ by $\% 20$ Type $\% 20$
and\%20Province.pdf, accessed June 2, 2011.

[23] Carbon Capture Journal, 2009, "Alberta finances Swan Hills project," http://www. carboncapturejournal.com/ displaynews.php?NewsID $=490$, published December 3, 2009 , accessed May 2011.

[24] Statistics Canada, 2011, Report on Energy Supply and Demand in Canada: 2007, Minister of Industry, Catalogue no. 57-003-X http://www.statcan.gc.ca/pub/57003-x/57-003-x2007001-eng. pdf, January 2010, accessed June 2011.

[25] Hatch, 2010, Final Report for Alberta Utilities Commission, Calgary, Alberta: Update on Alberta's Hydroelectric Energy Resources, H334053 Rev. 1, http://www.energy. alberta.ca/Electricity/pdfs/ AUCHydroelectricStudy.pdf, published February 26, 2010, accessed May 2011.

[26] FERC, 2011, "Issued Preliminary Permits," Federal Energy Regulatory Commission, http:// www.ferc.gov/industries/ hydropower/gen-info/licensing/ pre-permits.asp, updated May 5, 2011, accessed May 2011.
[27] NaiKun Wind Energy Group, Inc., 2011, "Federal Environmental Approval for NaiKun Wind Positions North B.C. to Become Canada's First Offshore Wind Producing Region," News Release, http://www.naikun.ca/ news_media/news.php?id=124, published March 17, 2011, accessed May 2011.

[28] AltaLink, L.P., 2011, “Alberta Electricity Future, Southern Alberta Transmisstion Reinforcement." http:// albertaelectricityfuture.com/ alberta/?page_id=19, accessed June 2011

[29] NaiKun Wind Energy Group, Inc., 2011, "The Project, Engineering," NaiKun Wind Development Inc., http://www.naikun.ca/the_project/ engineering.php, accessed May $02,2011$.

[30] AWEA, 2011, "Production Tax Credit (PTC)," American Wind Energy Association, http://www. awea.org/issues/federal_policy/ upload/PTC_April-2011.pdf, published April 2011, accessed June 2, 2011.

[31] Gilbert, R., 2010, "Alberta solar project a Canadian first," Daily Commercial News and Construction Record, http://www. dcnonl.com/article/id42003, published December 9, 2010 accessed May 2011.

[32] Utah Clean Energy, n.d., "Solar Salt Lake Project," http:// utahcleanenergy.org/our_work/ solar_salt_lake_project, accessed May 2011.

[33] Kurtz, S., 2009, Opportunities and Challenges for Development of a Mature Concentrating PhotovoltaicPower Industry, National Renewable Energy Laboratory, NREL/TP-52043208, http://www.nrel.gov/ pv/pdfs/43208.pdf, updated November 2009, accessed May 2011.

[34] Government of British Columbia, n.d., "British Columbia's

Mountain Pine Beetle Action Plan 2006-2011," http://www.for.gov. bc.ca/hfp/mountain_pine_beetle/ actionplan/2006/Beetle_Action_ Plan.pdf, accessed March 2011.

[35] Biocap Canada, 2008, An Information Guide on Pursuing Biomass Energy Opportunities and Technologies in British Columbia for First Nations, Small Communities, Municipalities and Industry, Produced for BC Ministry of Energy, Mines and Petroleum Resources, BC Ministry of Forests and Range, http://www.energyplan. 
gov.bc.ca/bioenergy/PDF/

BioenergyInfoGuide.pdf, accessed March 2011.

[36] U.S. DOE, 2010, "Biomass Mulit-Year Program Plan," U.S. Department of Energy, Office of the Biomass Program Energy Efficiency and Renewable Energy http://www 1 .eere.energy.gov/ biomass/pdfs/mypp.pdf, published March 2011, accessed June 2, 2011.

[37] Jennejohn, D., 2011, Annual U.S. Geothermal Power Production and Development Report, Geothermal Energy Association, http://geo-energy.org/pdf/ reports/April2011AnnualUS Geothermal PowerProductionand DevelopmentReport.pdf, published April 2011, accessed May 2011.

[38] Holm, A., L. Blodgett, D. Jennejohn, and K. Gawell, 2010, "Geothermal Energy: International Market Update," http://www.geo-energy.org/pdf/ reports/GEA_International_ Market_Report_Final_May_2010. pdf, published May 2010, accessed May 2011.

[39] U.S. DOE, n.d., Rocky Mountain Oilfield Testing Center (RMOTC), Geothermal Testing, http://www. rmotc.doe.gov/geothermal.html, accessed May 3, 2011.

[40] Borealis GeoPower, 2011, "Swan Hills Heat Recovery Project Proceeding, News, Borealis GeoPower," http://www. borealisgeopower.com/news/ details/swan-hills-heat-recoveryproject-proceeding, published April 6, 2011.

[41]GEA, 2010, "Canadian Geothermal Energy Association - Member Project Data Base," Geothermal Energy Association, http://www.cangea.ca/images/ uploads/Member $\% 20$ Projects $\% 20$ Database \%20-\%20October\%20 2010.pdf, published October 2010, accessed May 2011.

[42]MIT, 2006, The Future of Geothermal Energy: Impact of Enhanced Geothermal Systems (EGS) on the United States in the 21st Century, Massachusetts Institute of Technology, http:// geothermal.inel.gov/publications/ future_of_geothermal_energy.pdf, published 2006, accessed May 2011.

[43] BC Hydro 2010, "Ocean Energy Sector in British Columbia," British Columbia Canada's Pacific Gateway, http://www.empr.gov. bc.ca/EAED/InvestmentInfo/ Documents/Ocean27May2010. pdf, published May 2010, accessed May 2011.

[44] BC Hydro, 2002, Green Energy Study For British Columbia Phase 2: Mainland, British Columbia Hydro, Report No. E44, http:// www.bchydro.com/etc/medialib/ internet/documents/environment/ pdf/green_energy_study.Par.0001. File.greenenergystudy-summary. pdf, published October 2002, accessed May 2011.

[45] Martin, B., 2005, "What is sustainable energy?", BC Sustainable Energy Association, http://www.bcsea.org/learn/ get-the-facts/renewable-energytechnologies/tidal-power, published 2005, accessed May 2011.

[46] World Nuclear Association, 2011 , "World Uranium Mining," http:// www.world-nuclear.org/info/ inf23.html, updated April 2011, accessed May 2011.

[47] World Nuclear Association, 2010, "Supply of Uranium," http://www. world-nuclear.org/info/inf $75 \mathrm{html}$, updated December 2010, accessed May 2011.

[48] World Nuclear Association, 2011, "US Nuclear Fuel Cycle," http:// www.world-nuclear.org/info/ inf41_US_nuclear_fuel_cycle. html, updated April 2011, accessed May 2011.

[49]EIA, 2010, "U.S. Uranium Reserves - U.S. Forward-Cost Uranium Reserves by State, YearEnd 2008," Energy Information Administration, http://www.eia. gov/cneaf/nuclear/page/reserves/ ures.html, published July 2010 , accessed May 2011.

[50] Van Gosen, B. S., V. S. Gillerman, and T. J. Armbrustmacher, 2009, "Thorium Deposits of the U.S. - Energy Resources for the Future?" U.S. Geological Survey Circular 1336, http://pubs.usgs. gov/circ/1336/pdf/C1336.pdf, published 2009, accessed May 2011.

[51] National Energy Technology Laboratory, Presentation "Tracking New Coal-Fired Power Plants," January 14, 2011.

[52] Great River Energy, n.d., "Spiritwood Station," http:// www.greatriverenergy.com/ makingelectricity/newprojects/ spiritwoodstation.html, accessed June $2011 \mathrm{ml}$

[53] Nuclear Regulatory Commission, 2011, "Expected New Nuclear Power Plant Applications," http:// nrc.gov/reactors/new-reactors/ new-licensing-files/expected-new- 
rx-applications.pdf updated April 13, 2011, accessed May 2011.

[54] Centre for Energy, n.d., "Canada - Statistics", Canadian Centre for Energy Information, http://www.centreforenergy. $\mathrm{com} /$ FactsStats/Statistics. asp?Template $=5,0[2]$, accessed May 2011.

[55]EIA, 2011, State Electricity Profiles, Energy Information Administration, DOE/EIA0348(01)/2, http://pbadupws.nrc. gov/docs/ML1113/ML111361080. pdf, released April 15, 2011,, accessed May 2011

[56] Canadian Nuclear Safety Commission, 2010, "Bruce Power Alberta - Withdrawn Application," http://www. nuclearsafety.gc.ca/eng/ readingroom/newbuilds/ withdrawnapplications/index.cfm, modified May 20, 2010, accessed May 2011.

[57] Nuclear Regulatory Commission, 2011, "Expected New Nuclear Power Plant Applications," http:// nrc.gov/reactors/new-reactors/ new-licensing-files/expected-newrx-applications.pdf updated April 13, 2011, accessed May 2011.
[58] AREVA, n.d., "Eagle Rock Enrichment Facility," http:// us.areva.com/EN/home-203/ eagle-rock-enrichment-facility. html, accessed May 2011.

[59] Uranium Development Partnership, 2009, Capturing the full potential of the uranium value chain in Saskatchewan, http://www.gov. sk.ca/adx/aspx/adxGetMedia. aspx ?mediaId=767\&PN=Shared, published March 31, 2009, accessed May 2011.

[60] Government of Alberta, 2010, Fact Sheet: "Talk about upgrading and refining," http:// www.energy.alberta.ca/Oil/ pdfs/FSRefiningUpgrading.pdf, published October 2010, accessed May 2011.

[61] Navingo BV, 2011, "Canada: JV Proposes Second Kitimat LNG Terminal," http://www. lngworldnews.com/canada-jvproposes-second-kitimat-lngterminal/, posted March 29, 2011, accessed May 2011.

[62] DKRW Advanced Fuels, 2011, "Medicine Bow Fuel \& Power LLC," http://www. dkrwadvancedfuels.com/fw/ main/Medicine_Bow-111.html, published 2011, accessed May 2011.
[63] Ethanol Producer Magazine, 2011, "Canada Plants," BBI International, http://www. ethanolproducer.com/plants/ listplants/Canada/, modified June 1, 2011, accessed May 2011.

[64] WGA, 2009, "2009 Progress Report to Western Governors", Western Governors' Assocation, June 2009, accessed June 2011.

[65] Canadian Renewable Fuels Association, 2011, http:// www.greenfuels.org/uploads/ documents/crfabiodiese plantsandmap 13-05-11.pdf, published May 13, 2011, accessed June 2011.

[66] North American Electric Reliability Corporation, NERC Interconnections Map. http://www.nerc.com/page. php?cid=1191119, accessed May 2011.

[67]Edison Electric Institute, 2011, Transmission Projects: At a Glance, http://www.eei.org/ ourissues/ElectricityTransmission/ Documents/Trans_Project_lowres. pdf, published March 2011, accessed May 25, 2011.

[68] WGA, n.d., "Regional Transmission Expansion Project," Western Governor's Association, http://www.westgov.org/indes. php?option=com_content\&view $=$ article\&id $=311$ Itemid, accessed June 2011.

[69] ICF International, 2009, Natural Gas Pipeline and Storage Infrastructure Projections Through 2030, prepared for the INGAA Foundation Inc., http://www. ingaa.org/File.aspx? $\mathrm{id}=10509$, published October 20, 2009, accessed May 2011.

[70] National Energy Board, 2011, "Fact Sheet: Challenges for Future Natural Gas Deliverability in Canada," http://www.neb-one. gc.ca/clf-nsi/rnrgynfmtn/nrgyrprt/ ntrlgs/ntrlgsdlvrblty20112013/ fctsht1114-eng.pdf, published May 2011, accessed May 2011.

[71] Dogwood Initiative, 2009, Citizens Guide to Liquid Natural Gas in British Columbia, http://dogwoodinitiative.org/ publications/reports/lngguide, published May 2009, accessed May 2011.

[72] ONEOK Partners, 2011, "Bakken Shale Overview and Field Trip", http://phx.corporate-ir.net/ External.File?item=UGFyZW50S UQ9NDEzMjg0N3xDaGlsZEIEP TQyOTc1M3xUeXBIPTI=\&t=1, June 6-7, 2011, accessed June 2011 
[73] EIA, 2011, "Country Analysis Briefs: Canada," Energy Information Administration, http://www.eia.doe.gov/emeu/ cabs/Canada/pdf.pdf, published April 2011, accessed May 2011.

[74] Kinder Morgan, 2008, “Trans Mountain Expansion (TMX) Proposal," http://www. kindermorgan.com/business/ canada/tmx_documentation/ brochure_single_page.pdf, published Summer 2008, accessed May 2011.

[75] Enbridge Northern Gateway Pipeline, 2011, "Northern Gateway at a Glance," http:// northerngateway.ca/project-info/ northern-gateway-at-a-glance, accessed May 2011.

[76] Government of Alberta, 2011, "CCS Major Initiatives," www. energy.alberta.ca/Initiatives/1897. asp, updated June 1, 2011, accessed June 2011.

[77] Office of Petroleum Reserves, n.d., Department of Energy, www. fossil.energy.gov/programs/ reserves/npr/CO2_EOR_Fact_ Sheet.pdf, accessed May 2011.

[78] Cenovus Energy, n.d., "Operations: Weyburn," http:// www.cenovus.com/operations/ oil/weyburn.html, accessed May 2011.

[79] DOE, 2006, Energy Demands on Water Resources: Report to Congress on the Interdependency of Energy and Water, U.S.

Department of Energy, http:// www.sandia.gov/energy-water/ docs/121-RptToCongressEWwEIAcomments-FINAL. pdf, published December 2006, accessed May 2011.

[80] NETL, 2009, Existing Plants Program: Energy - Water $R \& D$, Technology Roadmap \& Program Plan, U.S. Department of Energy, Office of Fossil Energy, National Energy Technology Laboratory, http://www.netl.doe. gov/technologies/coalpower/ ewr/water/pdfs/Technology\%20 Roadmap\%20and $\% 20$ Program\%20Plan.pdf, published November 2009, accessed May 2011 .

[81]Forman, R. T. T., 2001, Landscape mosaics: The ecology of landscapes and regions, Cambridge University Press, Cambridge, United Kingdom, http://books.google.com/books?hl $=e n \& l r=\& \mathrm{id}=$ sSRNU_5P5nwC\& oi $=$ fnd\&pg $=$ PR13\&dq $=$ Forman,+ R.+T.+T.,+2001,+Landscape+Mo saics:+The+ecology+of+Landsca
pes+and+Regions\&ots=kE0lMNA YZC\&sig=1_SNc2Za1QNpVni6D islebo $\mathrm{Y} 408 \# \mathrm{v}=$ onepage $\& \mathrm{q} \& \mathrm{f}=\mathrm{fal}$ se, accessed May 2011.

[82] WGA, 2010, "Initiative on Wildlife Corridors and Crucial Habitat," Western Governors' Association, http://www.westgov. org/wildlife, accessed May 2011.

[83]EPA, 2011, 2011 U.S. Greenhouse Gas Emissions And Sinks: 1990-2009, U.S. Environmental Protection Agency, USEPA \#430-R-11-005, http://epa. gov/climatechange/emissions/ usinventoryreport.html, published February 2011, accessed May 2011.

[84]CAPP, 2010, Environmental Challenges and Progress in Canada's Oil Sands, Canadian Association of Petroleum Producers, http://www.capp.ca/ GetDoc.aspx?DocID=135721, accessed May 2011.

[85] IPCC, 2008, "Chapter 5: Analysing regional aspects of climate change and water resources," Climate Change and Water, Bates, B.C., Z.W. Kundzewicz, S. Wu, and J.P. Palutikof, Eds., Intergovernmental Panel on Climate Change, http:// www.ipcc.ch/pdf/technicalpapers/ccw/chapter5.pdf, published June 2008, accessed May 2011

[86] IEA, 2010, "Combined Heat and Power," Energy Technology Systems Analysis Program (ETSAP), http://www.etsap. org/E-techDS/PDF/E04-CHP-GSgct_ADfinal.pdf , accessed June 2011.

[87] AESO, 2010, "2010 Annual Market Statistics Data File," http://www.aeso.ca/ downloads/2010_Annual_ Market_Stats_Data_File.xls, accessed June 2011.

[88] USDA, 2011, Crop Production 2010 Summary, U.S. Department of Agriculture, National Agricultural Statistics Service, ISSN: 1057-7823, http:// usda.mannlib.cornell.edu/ usda/current/CropProdSu/ CropProdSu-01-12-2011_new_ format.pdf, published January 2011, accessed May 2011.

[89] AAFC, 2010, "Wheat Sector Profile, Part One: Overview," Market Outlook Report, 2, Agriculture and Agri-Food Canada. http://www.agr.gc.ca/ pol/mad-dam/index_e.php?s $1=$ pubs\&s $2=$ rmar\&s $3=$ php\&page =rmar_02_06_2010-11-26\#alt, published November 26, 2010 , accessed May 2011. 
[90] Huang, W-Y, 2009, Factors Contributing to the Recent Increase in U.S. Fertilizer Prices, 2002-08, U. S. Department of Agriculture, AR-33, http:// www.ers.usda.gov/Publications/ AR33/AR33.pdf, February 2009, accessed May 2011.

[91] Schnepf, R., 2004, Energy Use in Agriculture: Background and Issues, Congressional Research Service (CRS) Report for Congress, http://www. nationalaglawcenter.org/assets/ crs/RL32677.pdf, published November 19, 2004, accessed May 2011.

[92] CFI, 2010, "Statistics Canada - Service Bulletin: Fertilizer Shipments Survey 2010," Canada Foundation for Innovation, Catalogue no. 21-022-X, http:// www.cfi.ca/_documents/21-022x2010004-eng.pdf, published February 2011, accessed May 2011.

[93] Frigon, M., 2007, Fertilizers, Ethanol, and the Peaking of Natural Gas Production in Alberta, Parliamentary Information and Research Service, PRB 07-49E, http:// www.parl.gc.ca/Content/LOP/ ResearchPublications/prb0749-e. pdf, October 10, 2007, accessed May 2011.

[94] Scown, C. D., A. Horvath, T. E. McKone, 2011, "Water Footprint of U.S. Transportation Fuels," Environmental Science \& Technology, Vol. 45, pp. 25412553, http://www.library.nhs.uk/ booksandjournals/details.aspx?t $=$ water+footprint\&stfo=True\&s c=bnj.ovi.amed,bnj.ovi.bnia,bnj. ebs.cinahl,bnj.ovi.emez,bnj. ebs.heh,bnj.ovi.hmic,bnj.pub. MED,bnj.ovi.psyh\&p=1\&sf=srt . publicationdate\&sfld=fld. title\&sr=bnj.ovi\&did=ovid com:/bib/embase/ $2011179082 \& p c=5 \& i d=3$, published April 1, 2011, accessed May 2011.

[95] Nelson, L., A. Gribik, V. Maio, M. McKellar, M. Patterson, and $\mathrm{R}$. Wood, 2010, Integration of High Temperature Gas-Cooled Reactors into Industrial Process Applications, Idaho National Laboratory, Idaho Falls, ID. INL/ EXT09 16942 Revision 2.

[96] EIA, 2010, International Energy Outlook 2010, U.S. Energy Information Administration Report \#:DOE/EIA-0484.
[97]EIA, 2011, Annual Energy Outlook 2011, U.S. Energy Information Administration, DOE/ EIA-0383.

[98] National Energy Board, 2009, Canada's Energy Future: Infrastructure Changes and Challenges to 2020 - An Energy Market Assessment October 2009, http://www.neb-one.gc.ca/clf-nsi/ rnrgynfmtn/nrgyrprt/nrgyftr/2009/ nfrstrctrchngchllng2010/ nfrstrctrchngchllng2010-eng.pdf.

[99] Holden, M., 2011, Looking Overseas: Market Potential and Policy Considerations for West Coast Pipeline Development, Presented for the CanadaWest Foundation, April 2011.

\section{WEC Map References}

\section{Use for all maps:}

[ALL] ArcMap, Version 10.0, Olympia, WA: Environmental Systems Research Institute, Inc., http://www.esri.com/, published 2010, accessed May 2011.

\section{[M2] Figure 2: Crude Oil}

[1] Meyer, R., E. D. Attanasi, and P. A. Freeman, 2007, "Heavy Oil and Natural Bitumen Resources in Geological Basins of the World," United States Geological Survey, http://pubs.usgs.gov/ of/2007/1084/, updated March 29, 2007, accessed May 2011.

[2] NETL, n.d., "Technologies: Nation Carbon Sequestration Database and Geographic Information System (NATCARB)," National Energy Technology Laboratory, Department of Energy, http:// www.netl.doe.gov/technologies/ carbon_seq/natcarb/index.html, accessed May 2011.

\section{[M3] Figure 4: Natural Gas}

[1] EIA, 2009, "Coalbed Methane Fields, Lower 48 States," Energy Information Administration, http://www.eia.gov/oil_gas/rpd/ coalbed_gas.jpg, updated April 8, 2009, accessed May 2011.

[2] EIA, 2011, "North American Shale Plays," Energy Information Administration, http://www.eia. gov/oil_gas/rpd/northamer_gas. jpg, updated May 9, 2011, accessed May 2011.

[3] NETL, n.d., "Technologies: Nation Carbon Sequestration Database and Geographic Information System (NATCARB)," National Energy Technology Laboratory, Department of Energy, http://www.netl.doe.gov/ technologies/carbon_seq/natcarb/ index.html, accessed May 2011. 


\section{[M4] Figure 5: Coal}

[1] U.S. DOI, 2011, "Raw Data Download," nationalatlas.gov, U.S. Department of the Interior, http://www.nationalatlas.gov/ atlasftp.html?openChapters=chpg eol\#chpgeol, updated January 27, 2011, accessed May 2011.

\section{[M5] Figure 6: Waterways}

[1] ArcMap, Version 10.0, Olympia, WA: Environmental Systems Research Institute, Inc., http:// www.esri.com/, published 2010, accessed May 2011.

\section{[M6] Figure 7: Wind}

[1] Wind US Wind Data: 3Tier, Renewable Energy Risk Analysis, http://www.3tier.com/en/, accessed May 2011.

[2] Canada: Environment Canada, 2008, "Canadian Wind Energy Atlas," http://www.windatlas.ca/ en/maps.php, updated August 21, 2008, accessed May 2011.

\section{[M7] Figure 8: Solar}

No reference for this. We took various background info and then made our own.

\section{[M8] Figure 9: Biomass}

[1] Gap Analysis Program, 2010, "National Land Cover Gas Analysis Project," U.S.
Geological Survey, http:// 1c.gapanalysisprogram.com/ landcoverviewer/Downloads. aspx, published February 2010, accessed May 2011.

\section{[M9] Figure 10: Geothermal}

[1] SMU, n.d., "Geothermal Map of North America, 2004," Southern Methodist University, http://smu. edu/geothermal/2004NAMap/ 2004NAmap.htm, accessed May 2011.

\section{[M10] Figure 11: Tidal/Coastal}

[1] Cornett, A., 2006, "Figure 11: Annual mean wave power for sites in the NE Pacific," in Inventory of Canada's Marine Renewable Energy Resources, Canadian Hydraulics Centre, Natural Resources Canada, http:// canmetenergy-canmetenergie. nrcan-rncan.gc.ca/fichier.php/ codectec/En/2009-053_marine/ CHC-TR-041.pdf, published April 2006, accessed May 2011.

[2] Cornett, A., 2006, "Figure 10: Potential Tidal Current Resource Sites - Pacific Coast," in Inventory of Canada's Marine Renewable Energy Resources, Canadian Hydraulics Centre, Natural Resources Canada, http:// canmetenergy-canmetenergie. nrcan-rncan.gc.ca/fichier.php/
codectec/En/2009-053_marine/ CHC-TR-041.pdf, published April 2006, accessed May 2011.

\section{[M11] Figure 12: Uranium}

[1] Natural Resources Canada, 2009, "Uranium Resources," The Atlas of Canada, http://atlas.nrcan. gc.ca/site/english/maps/economic/ energy/uranium, updated September 2, 2009, accessed May 2011.

\section{[M12] Figure 15: Liquid Fuels}

[1] Ethanol Producer Magazine, n.d., "U.S. \& Canada Fuel Ethanol Plant Map," Mansfield Fuels, BBI International, http://www. ethanolproducer.com/plants/map/, accessed May 2011.

[2] Ethanol Producer Magazine, 2011, "Canada Plants," BBI International, http://www. ethanolproducer.com/plants/ listplants/Canada/, updated June 2, 2011, accessed May 2011.

[3] Kitimat LNG, "Project Description," http://www. kitimatlngfacility.com/Project/ project_description.aspx, accessed May 2011.

[4] DKRW Advanced Fuels, n.d., "Medicine Bow Fuel \& Power LLC," http://www. dkrwadvancedfuels.com/fw/
main/Medicine_Bow-111.html, accessed May 2011.

[5] Biodiesel, n.d., "NBB Member Plants: Biodiesel Locator,' National Biodiesel Board, http://www.biodiesel.org/ buyingbiodiesel/plants/biomaps/ biomaps.shtm\#app=d088\&4810selectedIndex $=2 \& \mathrm{fd} 8 \mathrm{~d}-$ selectedIndex $=3 \& 65 \mathrm{ce}-$ selectedIndex $=0$, accessed May 2011.

[6] Biodiesel, n.d., "NBB Member Plants," http://www.biodiesel.org/ buyingbiodiesel/plants/biomaps/ biomaps.shtm\#app=d088\&4810selectedIndex $=2 \& \mathrm{fd} 8 \mathrm{~d}$ selectedIndex $=3 \& 65 \mathrm{ce}-$ selectedIndex $=0$, accessed June 2011.

\section{[M13] Figure 17: Transmission Lines}

[1] SaskPower, n.d., "Available Generation," http://www. saskpower.com/about_us/ generation_transmission_ distribution/assets/system_map. pdf, accessed May 2011.

\section{[M14] Figure 18: Gas Pipelines}

[1] The World Factbook, 2008, "North America Pipelines map - Crude Oil (petroleum) pipelines - Natural Gas pipelines - Products pipelines," Information Technology Associates, http:// 
www.theodora.com/pipelines/ north_america_oil_gas_and_ products_pipelines.html, updated May 6, 2008, accessed May 2011.

[2] Centre for Energy, n.d., "Energy Facts \& Statistics, Maps: North America," Canadian Centre for Energy Information, http://www. centreforenergy.com/FactsStats/ MapsNorthAmerica/, accessed May 2011.

[3] Alaska Pipeline Project, n.d., "Proposed Pipeline Route," http:// www.thealaskapipelineproject. com/docs/alaska_pipeline_ project_map.pdf, accessed May 2011.

[4] MacKenzie Gas Project, n.d., "Main Map," http://www. mackenziegasproject.com/ theProject/overview/mainMap. html, accessed May 2011.

[5] TransCanada, n.d., "Horn River Map," http://www.transcanada. com/docs/Media_Centre/Horn River_Map.pdf, accessed May 2011.

[6] Pacific Northern Gas Ltd, n.d., "Systems Map," http://www.png. ca/company_map.cfm, accessed May 2011.

[7] Spectra Energy Corp., 2011, "New Projects: We're Meeting the Needs for Natural Gas Use," http://www.spectraenergy.com/ Operations/New-Projects/, accessed May 2011.

[8] Ruby Pipeline LLC, 2010, "Ruby Location Map," http:// www.rubypipeline.com/docs/ RubyOverviewMap.pdf, published June 18, 2010, accessed May 2011

[9] Ruby Pipeline LLC, n.d., "Ruby Map," http://www.rubypipeline. com/docs/Ruby_Map.pdf, accessed May 2011.

[10] TransCanada, 2010, "Bison Pipeline," Bison Pipeline LLC, http://bisonpipelinellc.com/, published November 2010 , accessed May 2011.

[11] Kern River Gas Transmission Company, 2011, "Expansion Projects: Apex Expansion," http://www.kernrivergas.com/ InternetPortal/Desktop.aspx, accessed May 2011.

[12] Colorado Interstate Gas, 2009 "High Plains Expansion Project," E1 Paso, http://www.elpaso.com/ highplains/default.shtm, accessed May 2011.

[13] Wyoming Interstate, 2006, "Kanda Lateral and Mainline Expansion," El Paso, http://www. elpaso.com/kanda/default.shtm, accessed May 2011.

\section{[M15] Figure 20: Oil Pipelines}

[1] EIA, n.d., "About U.S. Natural Gas Pipelines - Transporting Natural Gas," http://www.eia. gov/pub/oil_gas/natural_gas/ analysis_publications/ngpipeline/ ngpipeline_maps.html, accessed May 2011.

[2] Centre for Energy, n.d., "Energy Facts \& Statistics, Maps: North America," Canadian Centre for Energy Information, http://www. centreforenergy.com/FactsStats/ MapsNorthAmerica/, accessed May 2011.

[3] TransCanada, 2011, "Keystone Pipeline Project," TransCanada PipeLines Limited, http://www. transcanada.com/keystone.html, updated May 31, 2011, accessed June 2011.

[4] TransCanada, 2011, "Bakken Marketlink Project," TransCanada PipeLines Limited, http://www. transcanada.com/keystone.html, updated March 2, 2011, accessed May 2011.

[5] Ziola, A., and D. Harrison, 2011, Bakken Shale Overview and Field Trip, Oneok Partners, June 6-7, 2011.

[6] TranCanada, 2011, "Cushing Marketlink Project," TransCanada PipeLines Limited, http://www. transcanada.com/cushing.html, updated March 2, 2011, accessed May 2011.

[7] Enbridge, 2011, "Enbridge Expansion: Southern Access," http://www.transcanada.com/ cushing.html, accessed May 2011.

[8] Plains Midstream Canada, n.d., "Rainbow Pipeline II Project," http://plainsmidstream.com/assets/ files/Rainbow\%20PipelineII_ ProjectMap.pdf, accessed May 2011.

[9] CEPA, 2007, "Maps," Canadian Energy Pipeline Association, http://plainsmidstream.com/assets/ files/Rainbow\%20PipelineII ProjectMap.pdf, accessed May 2011.

[10] Pembina, 2007, "Growth Projects: Branching Out," http:// plainsmidstream.com/assets/ files/Rainbow\%20PipelineII ProjectMap.pdf, accessed May 2011

[11] Enbridge, 2011, "Southern Lights," http://www.enbridgeexpansion.com/expansion/main. aspx $? \mathrm{id}=1216 \& \mathrm{tmi}=491 \& \mathrm{tmt}=4$, accessed May 2011.

[12] Enbridge, 2011, "Alberta Clipper," http://www.enbridgeexpansion.com/expansion/main 
aspx?id=1218\&tmi $=292 \& \mathrm{tmt}=4$ accessed May 2011.

[13] Enbridge, 2011, "North Dakota System Expansion Phase 6," http://www.enbridgeexpansion.com/expansion/main. aspx? $\mathrm{id}=6576 \& \mathrm{tmi}=408 \& \mathrm{tmt}=4$, accessed May 2011.

[14] Enbridge, 2011, "Project Info," Enbridge Northern Gateway Pipelines, http://www. northerngateway.ca/project-info/ route-map, accessed May 2011.

[15] Kinder Morgan, 2011, "Kinder Morgan - Canada: Projects," http://www.kindermorgan.com/ business/canada/projects.cfm, accessed May 2011.

[16] Kinder Morgan, 2008, "Trans Mountain Expansion Proposal," http://www.kindermorgan. com/business/canada/TMX_ Documentation/brochure_single_ page.pdf, published Summer 2008, accessed May 2011.

[17] UNEV, 2007, "UNEV Pipeline, LLC (home page)," http://www. unevpipeline.com/default.htm, accessed May 2011.

\section{[M16] Figure 21: $\mathrm{CO}_{2}$ Pipelines}

[1] Dakota Gasification Company, n.d., "CO2 Pipeline," Basin Electric Power Cooperative,
http://www.dakotagas.com/Gas_ Pipeline/CO2_Pipeline/index. html, accessed May 2011.

[2] EMFI, n.d., "ChevronTexaco's Rangley Oil Field Operations," Energy and Minerals Field Institute, http://emfi.mines.edu/ emfi2005/ChevronTexaco.pdf, accessed May 2011.

[3] Kinder Morgan, 2011, "Sheep Mountain Pipeline," http://www. kindermorgan.com/business/CO2/ transport_sheepmtn.cfm, accessed May 2011.

[4] Kinder Morgan, 2011, "Kinder Morgan CO2 - McElmo Dome," http://www.kindermorgan.com/ business/co2/supply_mcelmo.cfm, accessed May 2011.

[5] Denbury Resources Inc., 2010, "Branching Out," WY Pipeline Authority, http://www. wyopipeline.com/information/ presentations/2010/October/ Denbury_CO2update.pdf, published October 26, 2010, accessed May 2011.

[6] Enhanced Oil Resources, 2007, "Company Goals and Objectives," http://www.enhancedoilres.com/ goals.htm, accessed May 2011.
[7] Enhance Energy Inc., "Alberta Carbon Trunk Line," http://www. enhanceenergy.com/co2_pipeline/ index.html, accessed May 2011.

[8] Shell, n.d., "About Quest - Quest Carbon Capture and Storage," http://www.shell.ca/home/content/ can-en/aboutshell/our_business/ business_in_canada/upstream/ oil_sands/quest/, accessed May 2011.

[9] Shell, 2010, "Quest CCS Project," http://www.shell.ca/home/content/ can-en/aboutshell/our_business/ business_in_canada/upstream/oil_ sands/quest/, published January 2010, accessed May 2011.

[10] Swan Hills Synfuels, 2009, "Projects - Swan Hills ISCG/ Sagitawah Power Project," http:// www.shell.ca/home/content/ can-en/aboutshell/our_business/ business_in_canada/upstream/ oil_sands/quest/, accessed May 2011.

[11] Project Pioneer, n.d., "Project Pioneer Proposed Pipeline Route," http://projectpioneer.ca/ sites/default/files/Project-PioneerProposed-Pipeline-Route.jpeg, accessed May 2011.

\section{[M17] Figure 22: Railways}

[1] NRCAN, 2008, "The Atlas of Canada," Natural Resources Canada, http://atlas.nrcan.gc.ca/ site/english/maps/economic/ transportation/pm_r, updated February 19, 2008, accessed May 2011.

[2] U.S. DOI, "May Layer Info: Railroads of the United States," U.S. Department of the Interior, http://www.nationalatlas.gov/mld/ railrdl.html, updated January 27 , 2011, accessed May 2011.

\section{[M18] Figure 23: Eco-regions}

[1] EPA, 2011, "Ecoregions of North America," U.S. Environmental Protection Agency, Western Ecology Division, http://www. epa.gov/wed/pages/ecoregions na_eco.htm, updated April 20, 2011, accessed May 2011. 


\section{Appendix B Tables}

\begin{tabular}{|c|c|c|}
\hline State/Province & $\begin{array}{l}\text { Total Production } \\
\text { Thousands of Barrels/Day }\end{array}$ & $\begin{array}{l}\text { Total Production } \\
\text { of Oil Sands }\end{array}$ \\
\hline Colorado & 78 & 0 \\
\hline Montana & 76 & 0 \\
\hline North Dakota & $218^{*}$ & 0 \\
\hline South Dakota & 5 & 0 \\
\hline Utah & 63 & 0 \\
\hline Wyoming & 141 & 0 \\
\hline Alberta & 1,650 & 1,490 \\
\hline British Columbia & 45 & 0 \\
\hline Saskatchewan & 57 & 0 \\
\hline WEC Total & 2,333 & 1,490 \\
\hline U.S. Total & 5,361 & \\
\hline Canada Total & 2,722 & 1,490 \\
\hline \multicolumn{3}{|c|}{$\begin{array}{l}\text { * The production of oil in North Dakota is rapidly increasing. In } 2010 \text { North Dakota produced an } \\
\text { average of nearly } 310,000 \text { barrels per day. hitps://www:dmr.nd.gov/oilgas/statss } 2010 \text { monthlystats pdf }\end{array}$} \\
\hline \multicolumn{3}{|c|}{$\begin{array}{l}\text { EIA, 2010, "Petroleum and Other Liquids - Crude Oil Production," U.S.Energy Information } \\
\text { Administration, http://www.eia.doe.gov/dnav/pet/pet_crd_crpdn_adc_mbblpd_a.htm, published July } \\
29,2010 \text {, accessed May 2010. }\end{array}$} \\
\hline \multicolumn{3}{|c|}{$\begin{array}{l}\text { EIA, n.d. "International Energy Statistics - Petroleum - Production," U.S. Energy Information } \\
\text { Administration, http://www.eia.doe.gov/cfapps/ipdbprojectliedindex3..ffm?tid=5\&pid=57\&aid=I\&cid } \\
=\text { regions\&syid=2006\&eyid=2010\&unit=TBPD, accessed May } 2011 .\end{array}$} \\
\hline \multicolumn{3}{|c|}{$\begin{array}{l}\text { Energy Resources Conservation Board, June 2010, Alberta's Energy Reserves } 2009 \text { and Supply/ } \\
\text { Demand Outlook 2010-2019, ST98-2010, http://www.ercb.ca/docs/products/STs/st98_2010.pdf }\end{array}$} \\
\hline
\end{tabular}

\begin{tabular}{|c|c|c|}
\hline \multicolumn{3}{|c|}{ Remaining Established Reserves } \\
\hline State/Province & Millions Barrels & Year of Estimate \\
\hline Colorado & 279 & 2009 \\
\hline Montana & 343 & 2009 \\
\hline North Dakota & 1,046 & 2009 \\
\hline Utah & 398 & 2009 \\
\hline Wyoming & 583 & 2009 \\
\hline Alberta & 1,437 & 2008 \\
\hline British Columbia & 104 & 2008 \\
\hline Saskatchewan & 1,229 & 2008 \\
\hline WECTotal & 5,419 & \\
\hline U.S. Total & 20,682 & 2009 \\
\hline Canada Total & 5,380 & 2008 \\
\hline \multicolumn{3}{|c|}{$\begin{array}{l}\text { EIA, 2010, "Petroleum and Other Liquids-Crude Oil Reserves, Reserves Changes, and Production," } \\
\text { Energy Information Administration, http:///www.eia.gov/dnav/pet/pet_crd_pres_a_EPCO_RO1_ } \\
\text { mmbbl_a.htm, published December 30,2010, accessed May 2011. }\end{array}$} \\
\hline \multicolumn{3}{|c|}{$\begin{array}{l}\text { UGS, n.d., "Proved Reserves of Crude Oil and Natural Gas Liquids in Utah, 1945-2009," Utah } \\
\text { Geological Survey, http://geology.utah.gov/emplenergydata/statistics/petroleum3.0/pdffT3.2\%20\&\%20 } \\
\text { F3.1\%20\&\%20F3.2.pdf, accessed May 2011. }\end{array}$} \\
\hline \multicolumn{3}{|c|}{$\begin{array}{l}\text { Energy Resources Conservation Board, June 2010, Allberta's Energy Reserves } 2009 \text { and Supply/ } \\
\text { Demand Outlook 2010-2019, ST98-2010, http://wwwercb.ca/docs/products/STs/st98_2010.pdf }\end{array}$} \\
\hline
\end{tabular}




\begin{tabular}{|c|c|c|}
\hline State/Province & Millions Cubic Feet & Year of Production \\
\hline Colorado & $1,511,654$ & 2009 \\
\hline Montana & 105,251 & 2009 \\
\hline North Dakota & 92,489 & 2009 \\
\hline South Dakota & 12,927 & 2009 \\
\hline Utah & 449,511 & 2009 \\
\hline Wyoming & $2,536,336$ & 2009 \\
\hline Alberta & $4,400,000$ & 2009 \\
\hline British Columbia & $1,100,000$ & 2008 \\
\hline Saskatchewan & 269,553 & 2009 \\
\hline WEC Total & $10,477,721$ & \\
\hline U.S. Total & $26,013,115$ & 2009 \\
\hline Canada Total & $5,633,000$ & 2009 \\
\hline World Total & $134,307,000$ & 2009 \\
\hline \multicolumn{3}{|c|}{$\begin{array}{l}\text { EIA, 2010, "International Energy Statistics - Natural Gas - Production," Energy Information } \\
\text { Administration, http://www.eia.gov/cfapps/ipdbproject/IEDIndex3.cfn?ttid=3\&pid=26\&aid=I, } \\
\text { accessed May 2011. }\end{array}$} \\
\hline \multicolumn{3}{|c|}{$\begin{array}{l}\text { Government of Alberta, 2011, "Energy - Natural Gas Statistics," http://www.energy.alberta.cal } \\
\text { NaturalGas/727.asp, updated June 1,2011, accessed June 2011. }\end{array}$} \\
\hline \multicolumn{3}{|c|}{$\begin{array}{l}\text { Saskatchewan Ministry of Energy and Resources, } 2008 \text {, "Natural Gas in Saskatchewan Fact Sheet," } \\
\text { http://www.er.gov.sk.caladx/aspx/adxGetMedia.aspx?DocID=6552,3384,5460,2936,Documents\&Med } \\
\text { ialD=20543\&Filename }=\text { Fact+Sheet+-+Gas+in+Sask+(Sept+8+2008).pdf,published September } 8 \\
2008, \text { accessed May } 2011 \text {. }\end{array}$} \\
\hline \multicolumn{3}{|c|}{$\begin{array}{l}\text { British Columbia - Canada's Pacific Gateway, 2010, British Columbia Natural Gas and Petroleum: } \\
\text { Yours to Explore 2010, http://www.emproov.bc.ca/OG/oilandgas/royalties/inflevcredit/Documents/ } \\
\text { YourstoExplore18Mar2010web.pdf, published March 18,2010, accessed May } 2011 \text {. }\end{array}$} \\
\hline
\end{tabular}

\begin{tabular}{|c|c|c|}
\hline State/Province & Billions Cubic Feet & Year of Estimate \\
\hline Colorado & 7,348 & 2009 \\
\hline Montana & 37 & 2009 \\
\hline Utah & 725 & 2009 \\
\hline Wyoming & 2,328 & 2009 \\
\hline Alberta & 2,260 & 2009 \\
\hline British Columbia & 90,000 & 2007 \\
\hline Saskatchewan & 1,600 & Not available \\
\hline WEC Total & 104,298 & 2009 \\
\hline U.S. Total & 21,875 & \\
\hline Canada Total & 143,860 & \\
\hline
\end{tabular}

EIA, 2010, "Coalbed Methane," Energy Information Administration, http://www.eia.gov/dnav/ng/ ng_enr_coalbed_a_EPGO_R51_BCf_a.htm, published December 30, 2010, accessed May 2011.

EPA, 2010, Coal Mine Methane Country Profiles, U.S. Environmental Protection Agency, http://www. globalmethane.org/documents/toolsres_coal_overview_ch6.pdf, published December 2010, accessed May 2011

Government of Saskatchewan, 2010, "Our Oil \& Gas Resources, Natural Gas in Coal," http://www. ir.gov.sk.ca/Default.aspx?DN=5108,3384,2936,Documents\#sectld, accessed June 2011 .

Cohen, D. M., n.d., "Coalbed methane activity cools off," World Oil Online, http://www.worldoil.com/ Article aspx? id $=38424$, accessed June 2011. 
Table 8. Shale gas estimated remaining established reserves.

\begin{tabular}{|c|c|c|}
\hline State/Province & Billions Cubic Feet & Year of Estimate \\
\hline Colorado & 4 & 2009 \\
\hline Montana & 137 & 2009 \\
\hline North Dakota & 368 & Not available \\
\hline Alberta & 40,000 & 2009 \\
\hline British Columbia & 23,000 & 2009 \\
\hline Saskatchewan & 10,600 & 2008 \\
\hline WEC Total & 74,109 & \\
\hline \multicolumn{3}{|c|}{ 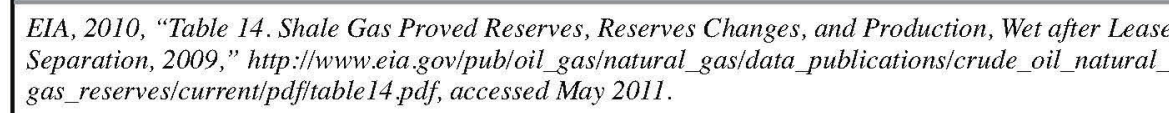 } \\
\hline \multicolumn{3}{|c|}{$\begin{array}{l}\text { Government of Alberta, 2011, "Shale Gas," htp://www.energy.alberta.ca/NaturalGas/944.asp, } \\
\text { updated June 1, } 2011 \text {. }\end{array}$} \\
\hline \multicolumn{3}{|c|}{ 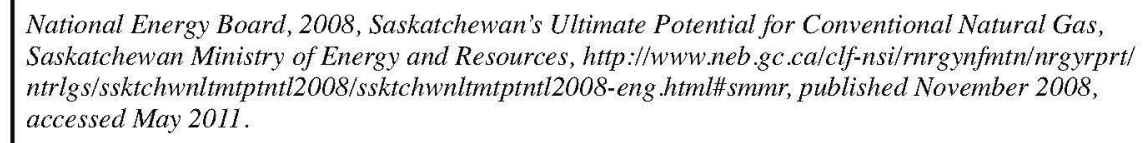 } \\
\hline
\end{tabular}




\begin{tabular}{|c|c|c|}
\hline State/Province & $\begin{array}{l}\text { Produced Coal } \\
\text { Million Short Tons/Year }\end{array}$ & Year of Estimate \\
\hline Colorado & 28.3 & 2009 \\
\hline Montana & 39.5 & 2009 \\
\hline North Dakota & 29.9 & 2009 \\
\hline Utah & 21.7 & 2009 \\
\hline Wyoming & 431.1 & 2009 \\
\hline Alberta & 34.3 & 2009 \\
\hline British Columbia & 23.2 & 2009 \\
\hline Saskatchewan & 11.6 & 2009 \\
\hline WEC Total & 619.6 & 2009 \\
\hline U.S. Total & $1,074.9$ & 2009 \\
\hline Canada Total & 69.3 & 2009 \\
\hline World Total & 7514.7 & 2009 \\
\hline \multicolumn{3}{|c|}{$\begin{array}{l}\text { EIA, 2010, Annual Coal Report, Energy Information Administration, http://www.eia.doe gov/cneafl } \\
\text { coal/page/acr/acr_sum.html, updated February } 3,2011 \text {, accessed May } 2011 \text {. }\end{array}$} \\
\hline \multicolumn{3}{|c|}{$\begin{array}{l}\text { Natural Resources Canada, n.d., "Coal Production by Type and Province," http://coal.ca/content/ } \\
\text { attachments/article/62/Coal\%20Production } \% 20 \text { by } \% 20 \text { Type\%20and\%20Province.pdf, accessed May } \\
2011 \text {. }\end{array}$} \\
\hline
\end{tabular}




\begin{tabular}{|c|c|c|c|c|c|c|c|c|}
\hline \multicolumn{6}{|c|}{ Current Installed Hydropower Capacity Generation } & \multicolumn{3}{|c|}{ Hydropower Potential } \\
\hline State/Province & $\begin{array}{l}\text { Number of } \\
\text { Plants }\end{array}$ & $\begin{array}{l}\text { Installed } \\
\text { Capacity } \\
\text { (MW) }\end{array}$ & $\begin{array}{l}2009 \text { Annual } \\
\text { Hydropower } \\
\text { Generation } \\
\text { (GWh) }\end{array}$ & $\begin{array}{l}2009 \text { Total } \\
\text { Annual } \\
\text { Generation* } \\
\text { (GWh) }\end{array}$ & $\begin{array}{l}\text { Hydropower \% } \\
\text { of Total Annual } \\
\text { Generation }\end{array}$ & $\begin{array}{l}\text { Feasible } \\
\text { Additional } \\
\text { Capacity } \\
\text { (MW) }\end{array}$ & $\begin{array}{l}\text { Feasible } \\
\text { Additional } \\
\text { Annual } \\
\text { Generation } \\
\text { (GWh) }\end{array}$ & $\begin{array}{c}\text { Hydropower } \\
\text { Potential Generation } \\
\text { Compared to } 2009 \\
\text { Generation }\end{array}$ \\
\hline Colorado & 57 & 666 & 2,058 & 50,738 & $4 \%$ & 1,782 & 7,805 & $379 \%$ \\
\hline Idaho & 127 & 2,346 & 9,057 & 12,172 & $78 \%$ & 4,244 & 18,589 & $196 \%$ \\
\hline Montana & 38 & 2,660 & 9,142 & 26,348 & $35 \%$ & 3,338 & 14,620 & $160 \%$ \\
\hline North Dakota & 1 & 486 & 1,475 & 34,196 & $4 \%$ & 80 & 350 & $24 \%$ \\
\hline South Dakota & 6 & 1,463 & 4,319 & 8,083 & $53 \%$ & 238 & 1,042 & $24 \%$ \\
\hline Utah & 67 & 256 & 697 & 43,404 & $2 \%$ & 802 & 3,513 & $504 \%$ \\
\hline Wyoming & 20 & 304 & 853 & 45,916 & $2 \%$ & 1,014 & 4,441 & $521 \%$ \\
\hline Alberta & 21 & 900 & 1,385 & 69,262 & $2 \%$ & 11,775 & 53,000 & $3827 \%$ \\
\hline British Columbia & 30 & 11,000 & 56,447 & 63,210 & $89 \%$ & 33,137 & 145,140 & $257 \%$ \\
\hline Saskatchewan & 7 & 853 & 3,000 & 17,900 & $17 \%$ & 3,955 & 17,323 & $577 \%$ \\
\hline WEC Total & 374 & 20,934 & 88,883 & 371,229 & $24 \%$ & 60,365 & 265,823 & $299 \%$ \\
\hline \multicolumn{9}{|c|}{$\begin{array}{l}\text { * From all electricity sources. } \\
\text { Canadian Hydropower Association, 2008, Hydropower in Canada: Past Present and Future, http://www.canhydropower.org/hydro_elpdfihydropower_past_present_future_en.pdf, accessed June 2011. } \\
\text { BChydro Regeneration. 2010. Our Facilities. http://www.bchydro.com/about/our_system/generation/our_facilities.html. accessed June } 2011 \text {. }\end{array}$} \\
\hline \multirow{2}{*}{\multicolumn{9}{|c|}{$\begin{array}{l}\text { Statistics Canada, 2011, Report on Energy Supply and Demand in Canada: } 2009 \text { Preliminary, Minister of Industry, Catalogue no. 57-003-X, http://www.statcan.gc.ca/pub/57-003-x/57-003-x2009000-eng,pdf, published } \\
\text { May 2011, accessed June 2011. } \\
\text { EIA, 2011, "Table 1.13.B. Net Generation from Hydroelectric (Conventional) Power by State by Sector, Year-to-Date through December } 2010 \text { and 2009," Energy Information Administration, http://www.eia.gov/cneafl } \\
\text { electricity/epm/table1_13_b.html, published April 14,2011, accessed May 2011. }\end{array}$}} \\
\hline & & & & & & & & \\
\hline \multicolumn{9}{|c|}{ 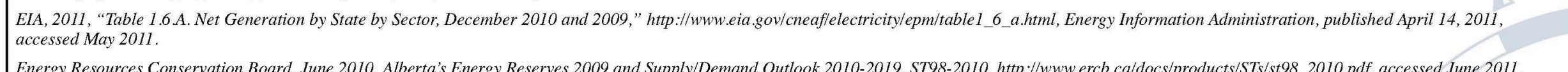 } \\
\hline
\end{tabular}




\section{Appendix B Tables}

Table 12. Wind power capacity.

\begin{tabular}{|c|c|c|}
\hline State/Province & $\begin{array}{c}\text { Potential Capacity } \\
\text { (MW) }\end{array}$ & $\begin{array}{c}\text { Installed Capacity } \\
\text { (MW) }\end{array}$ \\
\hline Colorado & 387,219 & 1,244 \\
\hline Idaho & 18,075 & 146 \\
\hline Montana & 944,004 & 375 \\
\hline North Dakota & 770,195 & 1,203 \\
\hline South Dakota & 882,412 & 313 \\
\hline Utah & 13,104 & 223 \\
\hline Wyoming & 552,773 & 1,099 \\
\hline Alberta & 64,000 & 591 \\
\hline British Columbia & 72,000 & 198 \\
\hline Saskatchewan & 42,500 & 171 \\
\hline WEC Total & $3,746,282$ & 5,563 \\
\hline
\end{tabular}

AWEA, 2011, "Installed Wind Capacity by State," American Wind Energy Association, http://www. windpoweringamerica.gov/docs/installed_wind_capacity_by_statexls, Accessed April 29, 2011.

Green River Opportunities, n.d., "Wind Power Part 3," http://www.greentech-opportunities.com/ Sector\%20Overview/WindPart3, accessed June 2011

Pembina, n.d., "Greening the Grid: Powering Alberta's Future with Renewable Energy," The Pembina Institute, http://pubs.pembina.org/reports/greeningthegrid-fs.pdf, accessed June 2011.

Energy Resources Conservation Board, June 2010, Alberta's Energy Reserves 2009 and Supply/ Demand Outlook 2010-2019, ST98-2010, http://www.ercb.caldocs/products/STs/st98_2010.pdf

\begin{tabular}{|l|}
\hline \multicolumn{2}{|l|}{$\begin{array}{l}\text { Table 13. Grid-connected solar power capacity. } \\
\text { Installed Solar Capacity } \\
\text { State/Province }\end{array}$} \\
(MW)
\end{tabular}




\begin{tabular}{|c|c|c|c|c|}
\hline State/Providence & $\begin{array}{c}\text { Forest Residues } \\
\text { (BDt/yr) }\end{array}$ & $\begin{array}{l}\text { Mill and Urban Wood Waste } \\
\text { (BDt/yr) }\end{array}$ & $\begin{array}{c}\text { Agricultural Residues } \\
\text { (BDt/yr) }\end{array}$ & $\begin{array}{l}\text { Grain Production } \\
\text { Green metric tonnes per year (t/yr) }\end{array}$ \\
\hline Colorado & 45,300 & 605,700 & $1,997,400$ & $5,518,600$ \\
\hline Idaho & 743,500 & $2,373,200$ & $2,139,000$ & $4,123,200$ \\
\hline Montana & 717,200 & $1,655,800$ & $2,130,200$ & $5,448,300$ \\
\hline North Dakota & 29,200 & 74,400 & $7,338,300$ & $21,238,600$ \\
\hline South Dakota & 133,900 & 271,400 & $7,213,100$ & $24,145,800$ \\
\hline Utah & 19,000 & 287,400 & 88,100 & 302,700 \\
\hline Wyoming & 62,900 & 282,180 & 112,300 & 452,600 \\
\hline Alberta & $4,600,000$ & 724,000 & $14,500,000$ & $30,098,900$ \\
\hline British Columbia & $11,940,000$ & $1,815,000$ & 143,900 & $2,167,100$ \\
\hline Saskatchewan & 579,500 & $2,174,600$ & $17,453,000$ & $46,164,000$ \\
\hline WEC Total & $18,870,500$ & $10,263,700$ & $53,115,300$ & $139,659,800$ \\
\hline \multicolumn{5}{|c|}{$\begin{array}{l}\text { Government of Alberta, 2010, "Alberta } 2009 \text { Crop Season in Review," Government of Alberta, Agriculture and Rural Development, http://wwwl.agric.gov.ab.ca/\$department/deptdocs.nsflall/sdd13100?opendocument } \\
\text { published April 27, 2010, accessed March } 2011 .\end{array}$} \\
\hline \multicolumn{5}{|c|}{ Knowledge Development Framework, https://bioenergykdf.netl, accessed March 2011.} \\
\hline \multicolumn{5}{|c|}{$\begin{array}{l}\text { Welling, H. H., and T.J. Shaw, } 2007 \text {, Energy From Wood Biomass Combustion In Rural Alberta Applications, The Agricultural Policy Framework (APF), A Federal-Provincial-Territorial Initiative, sponsored by the } \\
\text { Government of Canada and the Government of Alberta, http://www1.agric.gov.ab.ca/\$department/deptdocs.nsffall/apal1648/Sfile/alberta_wood_biomass_report.pdf? OpenElement, accessed March } 2011 \text {. }\end{array}$} \\
\hline \multicolumn{5}{|c|}{$\begin{array}{l}\text { Biocap Canada, 2008, An Information Guide on Pursuing Biomass Energy Opportunities and Technologies in British Columbia for First Nations, Smail Communities, Municipalities and Industry, Produced for BC } \\
\text { Ministry of Energy, Mines and Petroleum Resources, BC Ministry of Forests and Range, http://wwwenergyplan.gov.bc.calbioenergy/PDF/BioenergyInfoGuide.pdf, accessed March } 2011 \text {. }\end{array}$} \\
\hline \multicolumn{5}{|c|}{$\begin{array}{l}\text { Government of Saskatchewan, } 2007, \text { Report on Saskatchewan's Provincial Forests, http://www.er.gov.sk.ca/adx/aspx/adxGetMedia.aspx?DocID=10408,5460,2936,Documents\&MediaID=26483 \&Filename=Report+o } \\
n+\text { Saskatchewan's+Forests+March }+2007 \text { pdf, accessed March 2011. }\end{array}$} \\
\hline \multicolumn{5}{|c|}{$\begin{array}{l}\text { Government of Saskatchewan Department of Agriculture, "Agricultural Statistics Crops-Grains and Oilseeds," http://www.agriculture.gov.sk.ca/agriculture_statistics/HBV5_CropI.asp, accessed March 2011. } \\
\text { Natural Resources Canada, "About Uranium," http://www.nrcan.gc.caleneene/sources/uranuc/uranium/aboapr-eng.php, updated July 6, 2009,accessed March } 2011 .\end{array}$} \\
\hline
\end{tabular}




\section{Appendix B Tables}

\begin{tabular}{|c|c|c|c|}
\hline & U.S. & Canada & WEC \\
\hline \multicolumn{4}{|c|}{ Current } \\
\hline $\begin{array}{l}\text { Existing } \\
\text { Capacity (MW) }\end{array}$ & 3,087 & 0 & 58 \\
\hline $\begin{array}{l}2010 \text { Annual } \\
\text { Generation } \\
\text { (MW-hr) }\end{array}$ & $14,254 \times 10^{3}$ & 0 & $337 \times 10^{3}$ \\
\hline \multicolumn{4}{|c|}{ Projects Under Development } \\
\hline $\begin{array}{l}\text { Near } \\
\text { Commercial } \\
\text { Developments } \\
\text { (MW) }\end{array}$ & 1,409 & 0 & 198 \\
\hline $\begin{array}{l}\text { Initiated } \\
\text { Projects (MW) }\end{array}$ & 4,398 & 3 & 1,097 \\
\hline \multicolumn{4}{|c|}{ 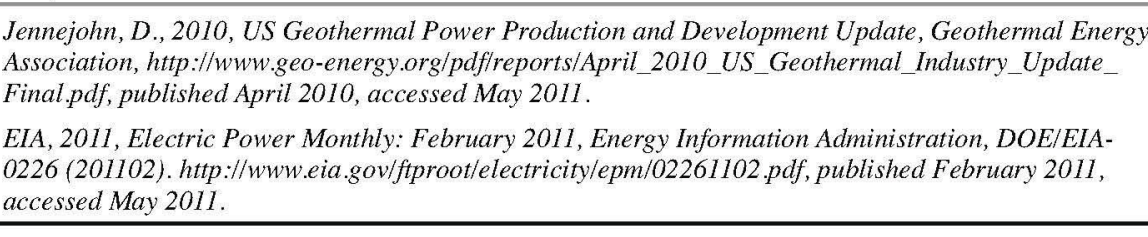 } \\
\hline
\end{tabular}




\begin{tabular}{|c|c|c|c|c|c|c|c|c|c|}
\hline State/Province & Coal & Petroleum & Natural Gas & Other Gas ${ }^{a}$ & Hydro & $\begin{array}{c}\text { Other } \\
\text { Renewables }^{b}\end{array}$ & Otherc & $\begin{array}{l}\text { Pumped } \\
\text { Storage }\end{array}$ & Total \\
\hline Colorado & 5,010 & 178 & 5,357 & 0 & 666 & $1,271.0$ & 0 & 563 & $13,045.0$ \\
\hline Idaho & 17 & 5 & 812 & 0 & 2,346 & 219.0 & 15 & 0 & $3,414.0$ \\
\hline Montana & 2,442 & 57 & 200 & 2 & 2,660 & 386.0 & 0 & 0 & $5,747.0$ \\
\hline North Dakota & 4,148 & 71 & 15 & 8 & 486 & $1,212.0$ & 0 & 0 & $5,940.0$ \\
\hline South Dakota & 497 & 230 & 722 & 0 & 1,463 & 320.0 & 0 & 0 & $3,232.0$ \\
\hline Utah & 4,871 & 25 & 2,002 & 0 & 256 & 265.0 & 0 & 0 & $7,419.0$ \\
\hline Wyoming & 5,929 & 7 & 120 & 92 & 304 & $1,104.0$ & 12 & 0 & $7,568.0$ \\
\hline Alberta & 5,971 & 10 & 5,201 & 0 & 900 & 914.0 & 0 & 0 & $12,996.0$ \\
\hline British Columbia & 0 & 0 & 1,163 & 0 & 11,000 & 290.0 & 0 & 0 & $12,453.0$ \\
\hline Saskatchewan & 1,664 & 0 & 1,029 & 0 & 8,53 & 171.2 & 0 & 0 & $3,717.2$ \\
\hline WEC Total & 30,549 & 583 & 16,621 & 102 & 20,934 & $6,152.2$ & 27 & 563 & $75,531.2$ \\
\hline \multicolumn{10}{|c|}{ a. For U.S. other gas includes blast furnace gas, propane gas, and } \\
\hline \multicolumn{10}{|c|}{$\begin{array}{l}\text { b. For U.S. other Renewables includes wood, black liqour, other wood waste, municipal solid waste, Landfill gas, sludge waste, agriculture byproducts, other biomass, geothermal, solar thermal, photovo } \\
\text { and wind. } \\
\text { c. For U.S. other includes batteries, chemicals, hydrogen, pitch, purchased steam, sulfur, tire-derived fuels and miscellaneous technologies.EIA, 2011, State Electricity Profiles, U.S. Energy Information } \\
\text { Administration, DOE/EIA-0348(01)/2, http://pbadupws.nrc.gov/docs/ML1113/ML111361080 pdf, released April 15, 2011, accessed May 2011. }\end{array}$} \\
\hline \multirow{2}{*}{\multicolumn{10}{|c|}{$\begin{array}{l}\text { Statistics Canada, 2011, Report on Energy Supply and Demand in Canada: } 2009 \text { Preliminary, Minister of Industry, Catalogue no. 57-003-X, http://www.statcan.gc.ca/pub/57-003-x/57-003-x2009000-eng.pdf, published } \\
\text { May 2011, accessed June 2011. } \\
\text { Energy Resources Conservation Board, June 2010, Alberta's Energy Reserves } 2009 \text { and Supply/Demand Outlook 2010-2019, ST98-2010, http://www.ercb.ca/docs/products/STs/st98_2010.pdf }\end{array}$}} \\
\hline & & & & & & & & & \\
\hline \multicolumn{10}{|c|}{$\begin{array}{l}\text { BChydro Regeneration. 2010. Our Facilties. http://www.bchydro.com/about/our_system/generation/our_facilities. html. accessed June } 2011 . \\
\text { MOVE: the a/b/c footnotes above the reference list. }\end{array}$} \\
\hline
\end{tabular}




\section{Appendix B Tables}

\begin{tabular}{|c|c|c|c|c|c|c|c|c|c|c|}
\hline State/Province & Coal & Petroleum & Natural Gas & Other Gas ${ }^{\mathrm{a}}$ & $\begin{array}{l}\text { Total Fossil } \\
\text { Fuel* }\end{array}$ & Hydropower & $\begin{array}{c}\text { Other } \\
\text { Renewables }^{b}\end{array}$ & $\begin{array}{l}\text { Pumped } \\
\text { Storage }\end{array}$ & Other & Total** \\
\hline Colorado & $31,636,023$ & 13,453 & $13,840,025$ & 0 & $45,489,501$ & $2,058,215$ & $3,245,973$ & $-108,658$ & 53,411 & $50,738,442$ \\
\hline Idaho & 82,565 & 41 & $1,643,595$ & 0 & $1,726,201$ & $9,506,510$ & 867,316 & 0 & 72,371 & $12,172,398$ \\
\hline Montana & $15,611,279$ & 490,433 & 77,762 & 1,447 & $16,180,921$ & $9,141,899$ & 915,566 & & 110,308 & $26,348,694$ \\
\hline North Dakota & $29,606,966$ & 45,016 & 16,606 & 43,526 & $29,712,114$ & $1,475,251$ & $3,009,102$ & 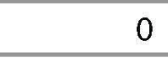 & 0 & $34,196,467$ \\
\hline South Dakota & $3,217,353$ & 8,320 & 80,334 & 0 & $3,306,007$ & $4,319,205$ & 426,756 & 0 & 31,318 & $8,083,286$ \\
\hline Utah & $35,526,126$ & 36,057 & $6,444,042$ & 27,933 & $42,034,158$ & 696,991 & 486,536 & 0 & 186,994 & $43,404,679$ \\
\hline Wyoming & $41,954,266$ & 50,181 & 488,014 & 284,361 & $42,776,822$ & 853,609 & $2,226,205$ & 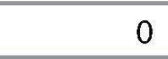 & 59,613 & $45,916,249$ \\
\hline Alberta & $41,557,210$ & Not available & Not available & Not available & $64,147,500$ & $1,385,000$ & $3,463,100$ & 0 & 266,400 & $69,262,000$ \\
\hline British Columbia & Not available & Not available & Not available & Not available & $6,764,000$ & $56,446,600$ & 0 & 0 & 0 & $63,210,600$ \\
\hline Saskatchewan & Not available & Not available & Not available & Not available & $14,900,000$ & $3,000,000$ & 0 & 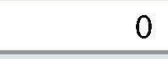 & 0 & $17,900,000$ \\
\hline WEC Total & & & & & $267,037,224$ & $88,883,280$ & $14,640,554$ & $(108,658)$ & 780,415 & $371,232,815$ \\
\hline \multicolumn{11}{|c|}{ 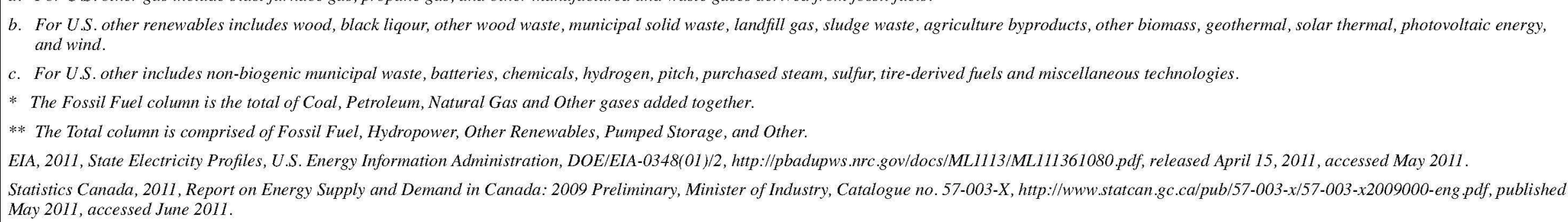 } \\
\hline
\end{tabular}




\begin{tabular}{|c|c|c|}
\hline State/Province & Number of Sites & $\begin{array}{l}\text { Barrels per } \\
\text { Calendar Day }\end{array}$ \\
\hline Colorado & 2 & 102,000 \\
\hline Montana & 4 & 187,600 \\
\hline North Dakota* & 1 & 58,000 \\
\hline Utah & 5 & 167,700 \\
\hline Wyoming & 8 & 204,600 \\
\hline Alberta & 3 & 432,200 \\
\hline British Columbia & 2 & 64,000 \\
\hline Saskatchewan & 2 & 128,000 \\
\hline \multicolumn{3}{|l|}{ Upgraders } \\
\hline Alberta & 5 & $1,209,000$ \\
\hline Saskatchewan & 1 & 75,000 \\
\hline WEC Refining Total & & $1,344,100$ \\
\hline WEC Upgrading Total & & $1,284,000$ \\
\hline \multicolumn{3}{|c|}{ * This facility will expand to 58,000 barrels per day capacity in 2012.} \\
\hline \multicolumn{3}{|c|}{$\begin{array}{l}\text { EIA, 2010, "Ranking of U.S. Refineries: U.S. Refineries Operable Capacity," Energy Information } \\
\text { Administration, http://www.eia.gov/neic/rankingsirefineries.htm, updated September 2010, accessed } \\
\text { May 2011. }\end{array}$} \\
\hline \multicolumn{3}{|c|}{$\begin{array}{l}\text { Government of Alberta, 2010, "Talk About Upgrading and Refining," Oil Sands Publications, Videos } \\
\& \text { Maps, "Talk About" Fact Sheets, http://wwwenergy.alberta.ca/Oillpdfs/F SRefiningUpgrading pdf, } \\
\text { published October 2010, accessed May } 2011 \text {. }\end{array}$} \\
\hline \multicolumn{3}{|c|}{$\begin{array}{l}\text { CPPI, 2011, "About the Industry - Refinery Operations," Canadian Petroleum Products Institute, } \\
\text { http://www.cppi.ca/index_e.php?p=65, accessed May 2011. }\end{array}$} \\
\hline
\end{tabular}

\begin{tabular}{|c|c|}
\hline \multicolumn{2}{|c|}{ Table 19. Biofuels production capacity. } \\
\hline State/Province & $\begin{array}{l}\text { Biofuels } \\
\text { (U.S. million gal. per year) }\end{array}$ \\
\hline Colorado & 148 \\
\hline Idaho & 67 \\
\hline Montana & 0 \\
\hline North Dakota & 497 \\
\hline South Dakota & 1,003 \\
\hline Wyoming & 13 \\
\hline Alberta & 225 \\
\hline British Columbia & 6 \\
\hline Saskatchewan & 90 \\
\hline WEC Total & 2,049 \\
\hline \multicolumn{2}{|c|}{ Knowledge Development Framework, htps://bioenergykdfnet/, accessed March 2011.} \\
\hline \multicolumn{2}{|c|}{$\begin{array}{l}\text { DOE-EERE, n.d., "Biomass Energy Data Book," Department of Energy, Energy Efficiency and } \\
\text { Renewable Energy, http://cta.ornl.gov/bedb/biopowershtml, updated 2010, accessed May } 2011 .\end{array}$} \\
\hline \multicolumn{2}{|c|}{$\begin{array}{l}\text { Ethanol Producer, 2011, "Canada Plants," Ethanol Producer Magazine, BBI International, http:/ } \\
\text { www.ethanolproducercom/plants/listplants/Canada, updated June 9, 2011, accessed June } 2011 .\end{array}$} \\
\hline
\end{tabular}




\section{Appendix B Tables}

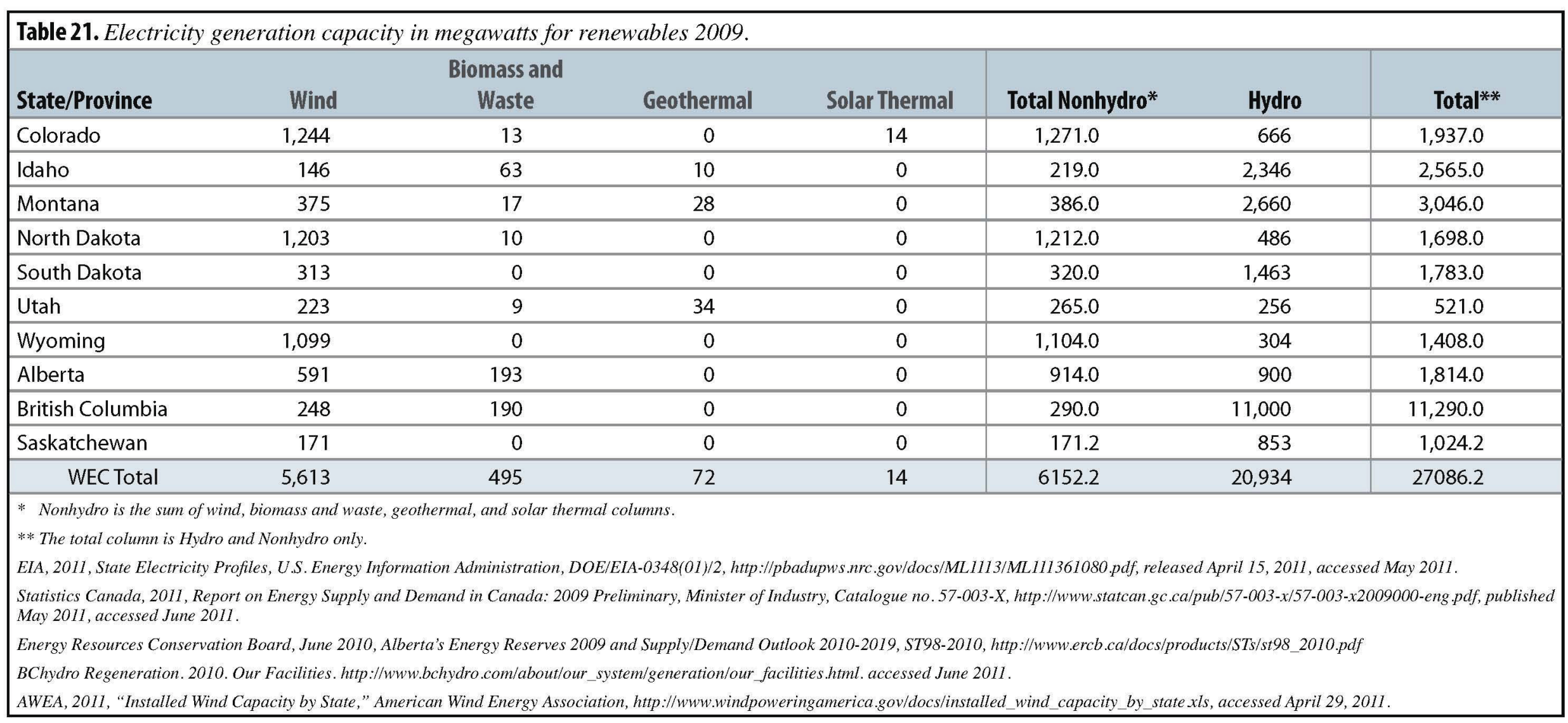





\section{Glossary}

Conventional resources: Hydrocarbon resources that can be exploited using traditional oil and gas extraction techniques.

Barrel: A unit of volume equal to 42 U.S. gallons, 35 imperial gallons, or 159 liters.

Barrels per calendar day: Measurement used to describe the amount of crude oil (measured in barrels) produced or consumed by an entity in one day.

Billion: For this document a billion is defined as $10^{9}$ or 'giga'.

Biofuels: Liquid fuels and blending components produced from biomass feedstocks, used primarily for transportation.

Biomass: Organic nonfossil material of biological origin constituting a renewable energy source.

\section{Barrel of oil equivalent (BOE): Unit of} energy based on the approximate energy released by burning one barrel (42 US gallons, 35 imperial gallons, or 158.9873 litres) of crude oil.

Capacity Factor: Measure of the performance of a power source over time as a percentage of its full power potential.

Coal bed: $\mathrm{A}$ bed or stratum of coal. Also called a coal seam.
Electricity generation: The process of producing electric energy or the amount of electric energy produced by transforming other forms of energy, commonly expressed in kilowatthours $(\mathrm{kWh})$ or megawatthours (MWh).

Energy source: Any substance or natural phenomenon that can be consumed or transformed to supply heat or power.

Established reserves: Reserves recoverable under current technology and present and anticipated economic conditions specifically proved by drilling, testing, or production, plus the portion of contiguous recoverable reserves that are interpreted to exist from geological, geophysical, or similar information with reasonable certainty.

Generation: Process of producing electric energy by transforming other forms of energy; also, the amount of electric energy produced, expressed in kilowatthours.

Gigawatt (GW): One billion watts or one thousand megawatts.

Installed Capacity: The maximum power output rating of a power plant (usually in MW) measured on an instantaneous basis.

In-place reserves: Total amount without regard to the cost or technology necessary to get at it.
Kilowatt (kW): One thousand watts.

Kilowatthour (kWh): A measure of electricity defined as a unit of work or energy, measured as 1 kilowatt $(1,000$ watts) of power expended for 1 hour. One $\mathrm{kWh}$ is equivalent to $3,412 \mathrm{Btu}$.

Megawatt (MW): One million watts of electricity.

Megawatthour (MWh): One thousand kilowatthours or 1 million watt-hours.

Metric ton or tonne: $\mathrm{A}$ unit of weight equal to 2,204.6 pounds.

Micro-hydro: Usually defined as $<100 \mathrm{~kW}$ (see Small-hydro).

Potential Capacity: The possible installed capacity that could potentially be achieved based on a hydropower resource assessment.

Proven reserves: Quantities, by analysis of geological and engineering data, can be estimated with reasonable certainty to be commercially recoverable, from a given date forward, from known reservoirs and under current economic conditions, operating methods, and government regulations.

Reserve: That portion of the demonstrated reserve base that is estimated to be recoverable at the time of determination (based on current knowledge, technology, and economics).
Short ton: A unit of weight equal to 2,000 pounds.

Small-hydro: Refers to upper limit capacities of between 20 and $30 \mathrm{MW}$, however, a value of up to $10 \mathrm{MW}$ total capacities is becoming generally accepted. Small hydro can be further subdivided into mini hydro (usually defined as $<500 \mathrm{~kW}$ and micro hydro $(<100 \mathrm{~kW})$.

Technically recoverable reserves: Resources which can be produced using currently available technology.

Ultimate recoverable reserves: The total expected recoverable volume from a well, lease, or field under present economic and engineering conditions; synonymous with total recovery.

Unconventional resources: Refers to a group of hydrocarbons that require stimulation for the extraction of commercial volumes. 
Idaho National Laboratory 2525 N. Fremont Ave

Idaho Falls, ID 83415

www.inl.gov

Point of Contact:

Michael Hagood

(208) 526-5315

michael.hagood@inl.gov 